\title{
USING Subordinated DebT to MONitor BANK HOLdING COMPANIES: IS IT FEASIBLE?
}

\author{
Diana Hancock and Myron L. Kwast ${ }^{\dagger}$ \\ Mail Stop \#153 \\ Board of Governors of the Federal Reserve System \\ Washington, DC 20551
}

\begin{abstract}
Academics, policymakers and bank supervisors have expressed considerable interest in using subordinated debt and other market data in the surveillance of banking organizations, especially large and complex financial institutions. However, little research has been devoted to developing practical means of implementing such an approach for subordinated debt. This paper attempts to fill a portion of this gap.

A major problem with using subordinated debt spreads is that accurate prices of individual subordinated debt issues are difficult to come by. The bond market is largely an over-the-counter market where dealer prices are proprietary. The approach used here is to evaluate a number of data sources, including price series from vendors and broker-dealers.

Our results indicate that subordinated debt spreads are most consistent across sources for the most liquid bond issues. We also find that the most liquid bonds are those that have a relatively large issuance size, have a relatively young age, have been issued by a relatively large banking organization, and are traded in a relatively robust overall bond market. Moreover, although there are substantial differences in spread levels for individual bonds across data sources, there is a high degree of concordance in rankings of banking organizations by their minimum spreads across issues. There is especially strong agreement about which large banking organizations are in the tails of the spread distribution at a given point in time. However, time series results indicate that movements of subordinated debt spreads at individual institutions are sensitive to the data source for bond prices, thus complicating interpretation of such movements.
\end{abstract}

On balance, our results support and provide guidance for the use of subordinated debt spreads in supervisory monitoring. However, they also support the need for careful judgment when interpreting such spreads, highlight difficulties with currently available data sources, and motivate the need for further research.

April 27, 2001 (4:36pm)

\footnotetext{
${ }^{\dagger}$ The views expressed are those of the authors and do not necessarily reflect those of the Board of Governors or its staff. The authors thank Mark Flannery, Erik Heitfield, Arthur Kennickell and Anthony Saunders for their comments and suggestions. In addition, the authors thank Matthew Cox and Kara Meythaler for their outstanding research assistance. All errors remain those of the authors.
} 


\section{INTRODUCTION}

Academics, policymakers, and bank supervisors have expressed considerable interest in using subordinated debt and other market data to aid in the surveillance of banking organizations, especially large and complex financial institutions. ${ }^{1}$ However, little research effort has been devoted to developing practical means of implementing such an approach for subordinated debt. This paper attempts to fill a portion of this gap.

We begin with an observation that secondary market prices for the subordinated notes and debentures issued by banking organizations could potentially be influenced by many factors other than a banking organization's default risk. First, the yield on each subordinated bond issued by a banking organization in the secondary market is likely to be affected by the specific characteristics of the instrument. For example, such yields will undoubtedly be affected by prevailing rates for debt with similar maturity. It may also be the case that bonds with atypically long or short maturities have higher secondary market yields than do bonds with more conventional maturities. ${ }^{2}$ In addition, characteristics that influence the timings of potential cash flows to bond investors (e.g., call options, step-ups, and frequency of coupon payment) would probably affect secondary yields. ${ }^{3}$

Second, the yield on a particular bond in the secondary market would potentially be affected by how frequently it is traded in the bond market (i.e., the liquidity of the instrument). In fact, discrepancies in recorded government bond prices across alternative data sources, which are perceived to be driven largely by the existence of illiquid bonds, appear to increase with a bond's age, its bid-ask spread, and the amount of bonds outstanding. ${ }^{4}$ Moreover, bid-ask spreads

\footnotetext{
${ }^{1}$ See Flannery (1998) for a discussion of the academic literature relevant to using market information in prudential bank supervision. Meyer (1999), in particular, has stressed the importance of differentiation in regulatory standards and supervisory practice between the largest, most complex and internationally active banks and all others.
}

${ }^{2}$ For example, Covitz, Hancock and Kwast (2000) present evidence that subordinated bonds with atypically long or short maturities appear to have significantly higher issuance spreads on average than do subordinated bonds with maturities in the 10 to 20 year range.

${ }^{3}$ Covitz, Hancock and Kwast (2000) report that coupon frequency significantly affects issuance spreads for subordinated bonds issued by banking organizations.

${ }^{4}$ See Sarig and Warga (1989). 
for corporate bonds, which are a measure of the cost of liquidity services in the trader versus the exchange markets, have been found to be significantly correlated with liquidity-related variables such as the rating of the bond, the age of the bond, and the issue amount outstanding. ${ }^{5}$ This evidence gleaned from the government and corporate bond markets supports the views of subordinated debt market participants. ${ }^{6}$ Some subordinated debt market participants, for example, have suggested that the market makes some distinction between on-the-run and off-therun bonds. That is, older, or off-the-run, issues are less liquid, particularly if the issuer of the older debt has not recently brought any large issues to the bond market, because bonds get absorbed into investors' portfolios. In addition, subordinated debt market participants perceived that the secondary market for larger issues is typically considerably more liquid than is the secondary market for smaller issues.

Third, investors may require a risk premium that is above and beyond the expected loss from default in order to compensate for systematic, rather than diversifiable, risk. Recently, researchers have demonstrated that corporate bond returns vary systematically with the same factors that are commonly accepted as explaining risk premiums for common stocks. ${ }^{7}$ If investors in common stocks require compensation for systematic risk, then it seems reasonable that investors in corporate bonds would also require compensation for such risk.

To date, researchers seeking to interpret banking organization bond spreads have focused on adjustments for instrument characteristics. For example, it has become standard practice to adjust yields on callable bonds to make them more comparable to non-callable yields. ${ }^{8}$ It has also become standard practice to adjust subordinated debt instrument yields by yields on Treasury securities with comparable maturity to take into account prevailing interest rates for debt with a similar maturity, though some market participants use swap curves from the libor market instead.

${ }^{5}$ See Warga (1991). Bid-ask spreads can proxy for liquidity since the trader, unsure of the true price of an illiquid bond, is prone to require a high margin of error. In addition, an illiquid bond is more difficult to locate and deliver than a liquid bond. In both cases, a high bid-ask spread indicates a relatively illiquid bond.

${ }^{6}$ See Board of Governors of the Federal Reserve System (1999, pp. 46-50).

${ }^{7}$ See Fama and French (1993) and Elton, Gruber, Agrawal, and Mann (2000).

${ }^{8}$ Another alternative is to consider only non-callable subordinated bonds. See, for example, Jagtiani, Kaufman and Lemieux (2000). 
With regard to designing a surveillance system for banking organization debt spreads, little guidance has been provided thus far for choosing among available corporate bond pricing sources or for choosing among the many subordinated bonds issued by an individual banking institution. ${ }^{9}$ That such choices can be important is demonstrated by the data presented in Figure 1. In the top panel, subordinated debt spreads over comparable maturity Treasury securities, computed using both Bloomberg and Interactive Data Corporation (IDC) bond pricing data, are presented for selected non-callable instruments issued by BankAmerica Corporation for the January 1997 to October 1999 period. ${ }^{10}$ The spread data computed from alternative data sources for "bond 1," for example, track each other fairly well until September 1998. ${ }^{11}$ After that date, however, IDC spreads are considerably larger for bond 1 than are Bloomberg spreads, moreover there are many weeks when the spread from one source rose while the spread from the other source fell. The divergence in IDC and Bloomberg spreads after September 1998 also occurs for "bond 2," with IDC spreads being larger than Bloomberg spreads. Interestingly, the IDC spreads for bond 1 and bond 2 diverged from one another in May 1999, despite the fact that the IDC spreads for these bonds had been fairly close to one another earlier in the sample period. Throughout the sample period, "bond 3" generally had the highest spread for the five bonds presented in Figure 1 for both Bloomberg and IDC spreads. Data for bond 3 was also quite discontinuous, regardless of the data source, and there was not much consensus on the level of its spread when both sources reported data. The time-series spread data for bonds 4 and 5 are

\footnotetext{
${ }^{9}$ Most studies that have considered the risk-sensitivity of banking organization subordinated debt spreads (e.g., Avery, Belton and Goldberg (1988), Gorton and Santomero (1990), and Flannery and Sorescu (1996)) have ignored these two issues: They used one source for bond prices and either a mean of option-adjusted spreads or a weighted average of option-adjusted spreads (with weights equal to the dollar amount outstanding at the time of issuance) in their empirical analysis. Presumably, one source was used because it was implicitly assumed that recorded bond prices were market clearing prices at which investors could buy (or sell) the underlying security at the close of the quotation day.

${ }^{10}$ In Figure 1, price data on a weekly basis for each instrument were obtained both from Bloomberg and from Interactive Data Corporation. The spread on each bond was calculated using derived yields computed by the Newton-Raphson iterative method and an interpolated Treasury yield of the same maturity. See discussion below for more details on spread calculations.

${ }^{11}$ In the aftermath of the Russian debt crisis, there was considerable bond market turmoil that widened spreads on subordinated debt during the August-October 1998 period (Board of Governors of the Federal Reserve System (1999, p.48)). Another factor that may have affected the subordinated debt spreads presented in figure 1 was the merger between Nationsbank and BankAmerica in September 1998.
} 


\section{Figure 1}

\section{BankAmerica Corporation Subordinated Debt Spreads ${ }^{1}$ (Selected Bonds, Weekly Data, January 1997 -- October 1999)}
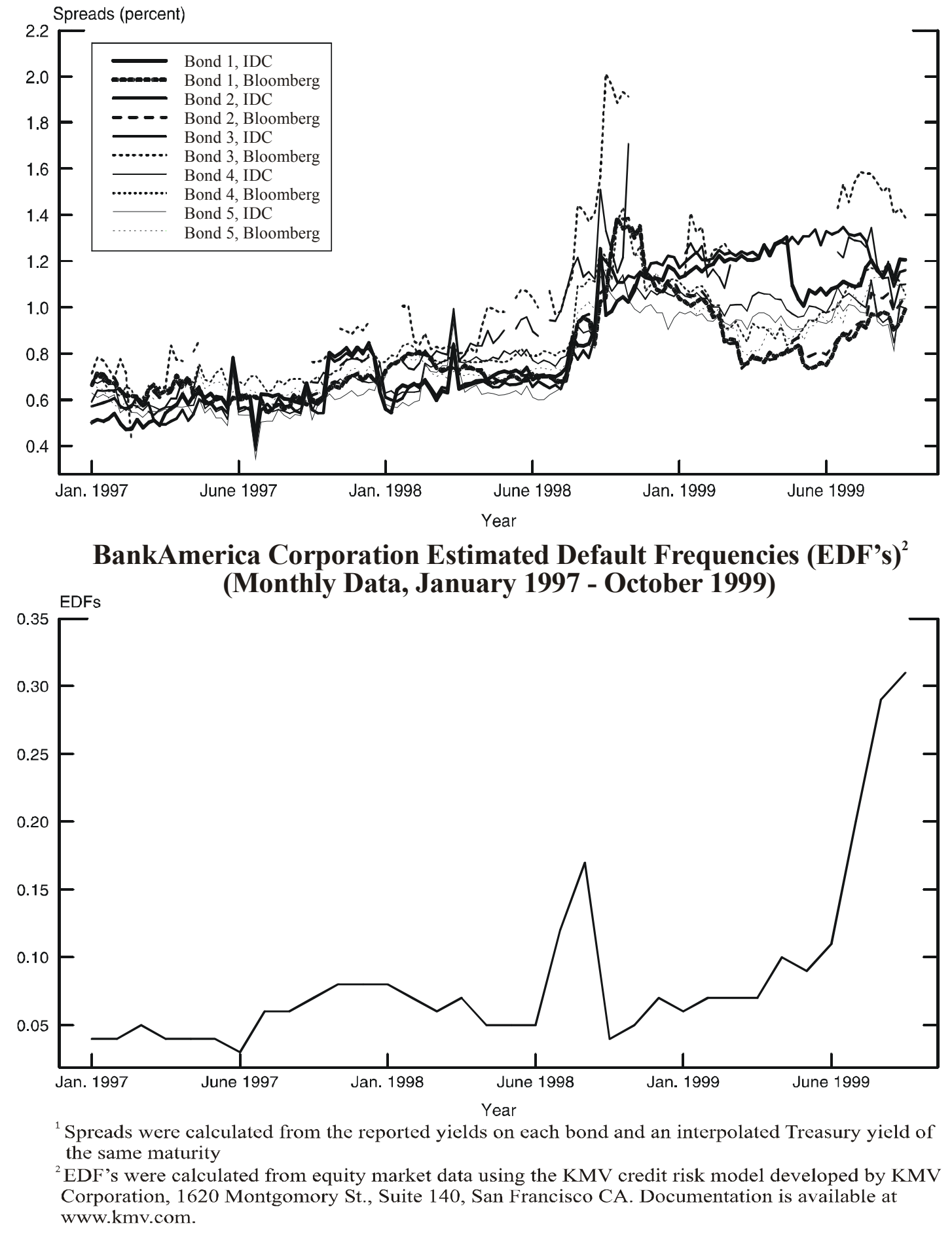
also striking. Bloomberg spreads for bonds 4 and 5 were larger than IDC spreads until September 1998. After that time, however, IDC spreads for bonds 4 and 5 were larger than Bloomberg spreads. Comparing the beginning and end of the sample period considered, there is greater divergence between Bloomberg and IDC spreads for each bond near the end of the period.

For comparison purposes, estimated default frequencies (EDFs) calculated using BankAmerica Corporation equity prices and the KMV model are presented in the bottom panel of figure 1. ${ }^{12}$ This barometer of default risk has a spike in late-summer 1998, as do most of the subordinated debt spreads presented in the top panel. While EDFs increased throughout 1999 for BankAmerica, it is unclear whether its subordinated debt spreads also steadily increased. Early in that year, Bloomberg spreads fell for all five bonds, but IDC spreads rose for bonds 1 and 2. Late in that year, some spreads declined while others increased. Clearly, in this specific case, inferences from the bond market about default risk and their correspondence with EDFs derived from equity market data would depend not only on the source of bond pricing data, but also on what instruments are chosen for surveillance purposes.

To the extent that differences in spreads across data sources and across individual bonds issued by an organization can be understood, it is likely that bond market information combined with stock market and supervisory information would be useful for shortening the length of time it takes to identify changes in bank condition or risk exposure, and for providing more accurate forecasts of future changes in bank condition. Since the models used to calculate estimated default frequencies from equity data may yield misleading results when their assumptions are violated, the bond market could potentially provide a signal that would indicate when such assumptions might be violated. Indeed, these may precisely be the cases where having information from both markets is beneficial to supervisors. In addition, equity investors may primarily be concerned about a banking organization's non-default states, whereas subordinated

\footnotetext{
${ }^{12}$ The KMV credit risk model estimates EDFs by determining a "distance to default" and a volatility of that distance by combining equity price levels, balance sheet information and industry characteristics with various assumptions. Documentation on the KMV credit risk model is available at http: www.kmv.com.
} 
debt holders (and bank supervisors) are primarily concerned with default states. ${ }^{13}$ This is because bond holders are exposed to loss, but do not benefit from any upside gains that accrue to risk-taking. ${ }^{14}$ This reasoning suggests that bondholders may provide a clearer signal of a firm's financial condition. Moreover, it is widely perceived that sampling multiple signals of bank condition, even it they are noisy signals, can often provide a more accurate estimate of a banking organization's true condition. ${ }^{15}$ Thus, there are strong reasons to believe that both stock and bond markets could provide useful information to supervisors and market participants. ${ }^{16}$

This paper focuses on developing criteria for bonds to be included in a supervisory monitoring system. The approach is to utilize multiple data sources on subordinated bond prices to infer which bonds issued by banking organizations are actively-traded so that they are least likely to have large liquidity premiums built into their yields or to have prices that are largely driven by technical factors. Such bonds would presumably contain cleaner measures of bond market participant assessments of the default risk of each banking organization. The analysis suggests that the liquidity of a bond depends on its issuance size, on the age of an issue, on whether the issuer is classified by bank supervisors as a large, complex, banking organization, and on the overall liquidity of the bond market. Indeed, spread data are most consistent across data sources for large, complex, organization debt that has been outstanding less than three years and that has an issuance size greater than $\$ 150$ million dollars.

The time-series movements of subordinated debt spreads are also considered. Using a time-series model, which is estimated using two alternative data sources for bond prices, it is found that it is difficult to make inferences about the systematic factors that might drive each

\footnotetext{
${ }^{13}$ Consistent with this view, Berger, Davies, and Flannery (2000) found evidence that neither equity market data nor supervisory assessments Granger cause the other.

${ }^{14}$ This is particularly true for subordinated debt holders. Among bank liabilities, subordinated notes and debentures are uninsured and among the first (after equity) to lose value in the event of the failure of a banking organization. Since passage of the Federal Deposit Insurance Corporation Improvement Act (FDICIA) in late 1991, subordinate debt holders likely view a bailout as highly improbable. Depositor preference laws reinforce this view.

${ }^{15}$ See Flannery (1998, p. 297).

${ }^{16}$ Market participants have said that they follow both bond and equity markets. While subordinated debt and equity price movements were viewed as normally tending to move together, subordinated debenture price movements were generally deemed to have value added relative to stock price movements. See Board of Governors of the Federal Reserve System (1999, p. 16)
} 
banking organization's debt spreads, because the magnitude of, and statistical significance of, coefficients crucially depend on the data source. These findings suggest that models used to interpret the time-series movements of debt spreads should be estimated using multiple data sources.

The paper proceeds as follows. Section 2 describes the alternative data sources that are used and develops some criteria for selecting bonds issued by banking organizations to be used for monitoring purposes. Section 3 discusses the time-series model for subordinated debt spreads and what the estimates suggest for bond market surveillance by bank supervisors. Section 4 concludes with a discussion of the Federal Reserve's experience to date with a surveillance system that uses both stock and bond prices.

\section{DATA COMPARISONS ACROSS SOURCES WITH INFERENCES FOR SUPERVISORY MONITORING}

There is a consensus among market participants and researchers that accurate historical data on corporate bond prices are difficult to come by. The two sources of generally available price quotes are exchange prices (e.g., the New York or American Stock Exchanges) and institutional prices from major over-the-counter dealers (e.g., Goldman Sachs, Lehman Brothers, and Merrill Lynch). Exchange prices primarily reflect the odd-lot activities of individual investors, cover only a small number of bond issues, and are based on a negligible portion of total trading activity. Institutional data - often obtained indirectly through services such as Bloomberg Financial Markets - cover a larger number of bonds and offer prices at which large positions could have been or indeed were transacted. In many cases, however, these prices are so-called "matrix prices," which are determined by using rules that specify the addition of a

fixed rate spread over either an actively traded benchmark security issued by the same company, another company's issue with similar rating, maturity and coupon, or a US Treasury issue. Between these two extremes, some commercial bond pricing services provide a mix of exchange and matrix prices. For example, Standard \& Poors, Moodys, and IDC prioritize their data sources, so that they report exchange-based prices when they are available, but fill in the data series with either an institutionally-based matrix bid price or a dealer bid quote when a bond 
does not trade for a week or more. ${ }^{17}$

In this study, weekly data on subordinated debt spreads calculated from weekly price data from two vendors (Bloomberg and IDC) are compared. ${ }^{18}$ Each spread was calculated from reported bond prices from each source using derived yields on each bond calculated by the Newton-Raphson iterative method and an interpolated Treasury yield of the same maturity. ${ }^{19}$ In addition, daily subordinated debt spreads provided for specific dates by two broker dealers in the subordinated debt market (Merrill Lynch and Chase Securities) are compared with daily spreads on those dates calculated from Bloomberg price data. ${ }^{20}$

\section{COMPARING VENDOR DATA}

For the comparison between Bloomberg and IDC subordinated debt spreads, data for the January 1997 to October 1999 period were used on 265 bonds that were issued by 40 bank holding companies. As exemplified in figure 1, time-series plots of the data, by bank holding company, revealed several differences. First, the data for some bonds during this period are quite discontinuous (i.e., there are distinct gaps in the time-series data). In some cases, IDC has more time-series data on such bonds, but in other cases Bloomberg has more time-series data on them. Second, in some cases, the price data are scanty no matter which of these alternative data sources is used. Third, there can be large discrepancies in spreads calculated from the two

\footnotetext{
${ }^{17}$ See Warga and Welch (1993) for an example where there are significant time-series differences between trader quotes, institutional data, and data based on a mix of exchange prices and matrix prices.

${ }^{18}$ The Federal Deposit Insurance Corporation shared their IDC price data with us for this purpose. These data are for the last business day of each week. The Bloomberg data used in this study is the "generic" bond pricing series constructed using the consensus method, which averages observed trading prices after dropping the highest and lowest observations. A minimum of three observations is required, after dropping the highest and lowest observations, for a price to be valid, otherwise a missing value is entered for the trading price.

${ }^{19}$ The term structure of Treasury interest rates was identified for each date by using a smoothing spline of the forward rate curve that incorporates a "roughness" penalty determined by generalized cross validation. The splining technique is described in Fisher, Nychka and Zervos, (1995).

${ }^{20}$ Alexa Berghager (Federal Reserve Bank of New York) provided us with the spread data from broker dealers for this purpose. The spreads provided by Merrill Lynch are approximately one week apart, but Chase Securities spreads are generally provided for each business day. Because we only had weekly data for the last business day of the week from IDC, only Bloomberg data is compared with the data from broker dealers.
} 
sources even when prices are reported almost every week by both sources. ${ }^{21}$

The top panel of figure 2 presents a histogram of subordinated debt spread discrepancies between Bloomberg and IDC pricing data sources for the 265 bonds considered here. This histogram is intriguing for at least three reasons. First, it is not centered around zero. In fact, the mean discrepancy between Bloomberg and IDC spreads in our sample is 6.33 basis points with a standard deviation of 0.24 . Second, the histogram presented in figure 2 is not symmetric. That is, it has more observations in the positive (right) tail than in the negative (left) tail. This means that the Bloomberg spread is larger than the corresponding IDC spread more frequently than not. Third, the histogram has tails that are thicker than would be observed with normally distributed discrepancies. $^{22}$

For bonds that are not actively traded, it seems reasonable to expect that large discrepancies in prices across sources could develop. There are several reasons why such discrepancies could arise and even persist for illiquid securities. First, each source likely uses different traders or broker dealers for pricing information. The price records need not be simultaneous, particularly if the bond is not traded as frequently as other bonds. Moreover, a lack of similar reference bonds may cause different traders to guess differing prices for the illiquid bond when matrix pricing methods are used. Second, exchange-based prices can contain significant liquidity-driven noise. ${ }^{23}$ Third, because it would be more difficult for investors to arbitrage price differences between illiquid securities, quote disparities for illiquid securities could persist for some time. ${ }^{24}$

Since the liquidity of both government bonds and corporate bonds has been found to be

\footnotetext{
${ }^{21}$ Interestingly, this feature of the historical data is also borne out each day on Bloomberg terminal screens. For a given instrument issued by a bank holding company, it is not unusual for a Bloomberg terminal screen with IDC information selected to provide different prices than a Bloomberg terminal screen with Bloomberg Fair Value information selected.

${ }^{22}$ More formally, quantile-quantile plots of bond spread discrepancies indicated that: (1) the tails of distributions stratified by issuance size are heavier for smaller issues; (2) the tails of the spread discrepancy distribution for bonds less than 3 years old are heavier than the corresponding tails of the spread distribution for bonds 3 to 5 years old; and, (3) tails of distributions stratified by bond age exhibited both skewness and kurtosis.

${ }^{23}$ For example, Nunn, Hill and Schneeweis (1986) reported that mean bond returns calculated with Merrill Lynch Securities Pricing Service institutional prices (i.e., matrix prices) and the Moody's Bond Record exchangebased prices are significantly different. For a random sample of 170 bonds during 1975 through 1980, the mean returns computed with institutional prices increased with higher default risk (as expected), but mean returns computed with exchange-based prices did not. These findings raise concerns about the effects of illiquidity on bond prices recorded by exchanges, as well as biases that may be built into matrix prices. be small.

${ }^{24} \mathrm{If}$ the prices in each data source were firm quotes in liquid securities, then price disparities would have to
} 
Figure 2

Histograms of Subordinated Debt Spread Discrepancies

between Bloomberg and Interactive Data Corporation (IDC) Data

265 Bonds, Weekly Data, January 1997 - October 1999
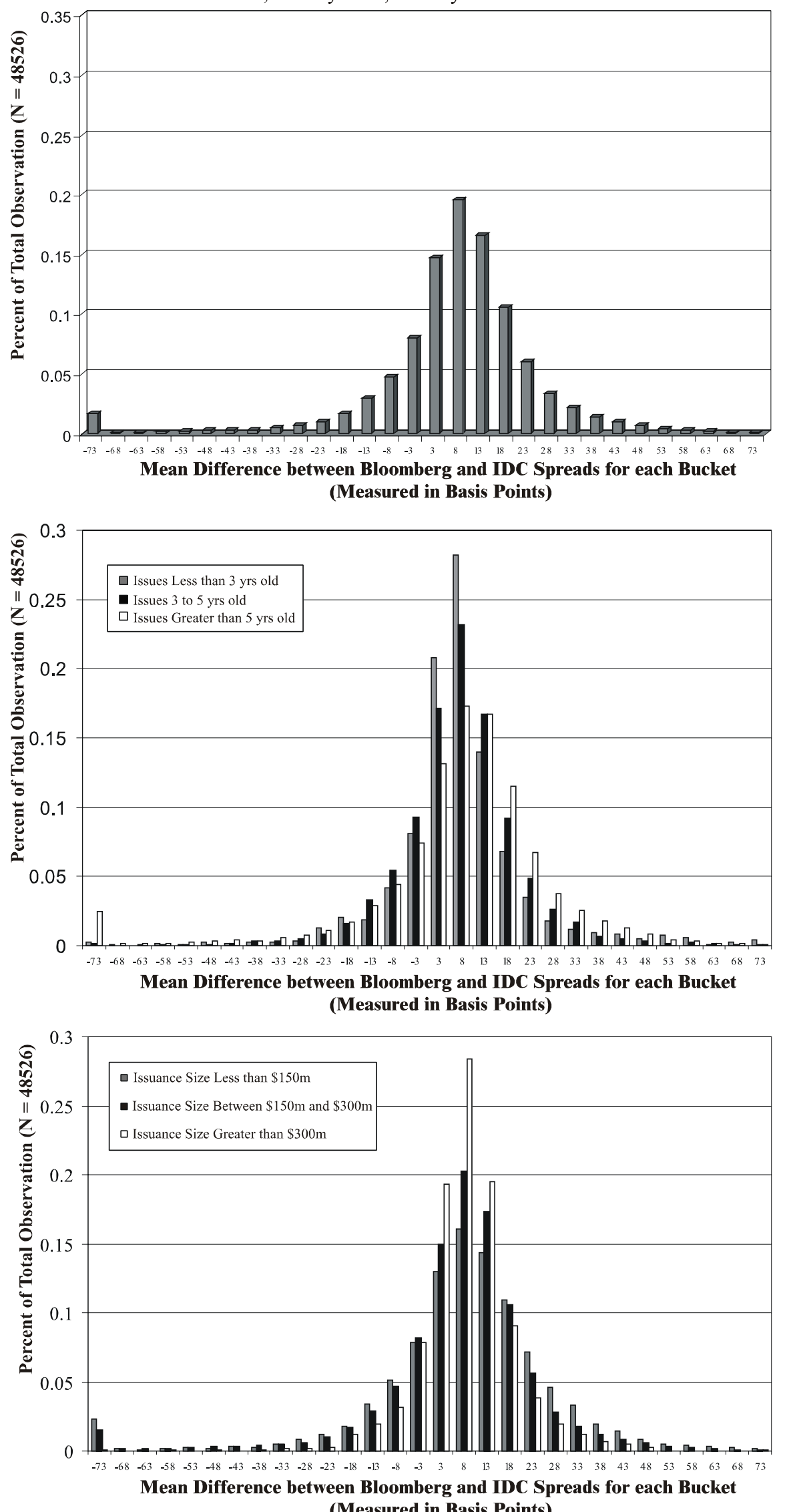

(Measured in Basis Points) 
related to the age of bonds and their issuance size, we considered how the distribution of discrepancies between Bloomberg and IDC spreads for our sample of banking organization subordinated debentures changed when we stratified bonds by their age (less than 3 years since issuance, 3 to 5 years since issuance, more than 5 years since issuance) and by issuance size (less than $\$ 150$ million, $\$ 150$ million to $\$ 300$ million, greater than $\$ 300$ million). The middle panel of figure 2 presents histograms of subordinated debt spread discrepancies between Bloomberg and IDC pricing data sources for the bonds stratified by age. It is readily apparent that the tighter distributions with the least weight in their tails are for the younger bonds. For example, spread discrepancies for bonds outstanding three years or less had a mean of 6 basis points with a standard deviation of .13, whereas spread discrepancies for bonds outstanding more than five years had a mean of 6 basis points with a standard deviation of .28. Indeed, relatively large discrepancies were more frequently observed for bonds that had been outstanding more than five years. These differences among the histograms of spread discrepancies by age of bond suggests that trading declines as bonds mature.

The bottom panel of figure 2 presents histograms of subordinated debt spread discrepancies between Bloomberg and IDC pricing data sources for the bonds stratified by issuance size. In this case, the tightest distribution of spread discrepancies is for bonds with issuance sizes greater than $\$ 300$ million. ${ }^{25}$ Moreover, bonds with issuance sizes between $\$ 150$ million and $\$ 300$ million have spread discrepancies that are more tightly distributed than the spread discrepancies for bonds with relatively smaller issuance sizes. ${ }^{26}$ The decreased dispersion in spread discrepancies for larger issues suggests that there may be a positive correlation between the flow of trade in a particular bond and its amount outstanding at issuance.

Considering only bonds issued by holding companies classified as large, complex, banking organizations by bank supervisors yielded similarly shaped discrepancy histograms to the ones presented in figure 2 with stratifications by age of bond and by issuance size. In fact, the spread discrepancy histogram for the subset of bonds that were recently issued (i.e., within three years) by LCBOs with an issue size greater than $\$ 300$ million indicated that these

\footnotetext{
${ }^{25}$ The distribution of spread discrepancies for bonds with issuance size greater than $\$ 300$ million has a mean equal to 7 basis points and standard deviation equal to 0.11 .

${ }^{26}$ The distribution of spread discrepancies for bonds with issuance sizes between $\$ 150$ million and $\$ 300$ million has a mean equal to 6 basis points and standard deviation equal to 0.25 , whereas the distribution of spread discrepancies for bonds with smaller issuance sizes has a mean equal to 8 basis points and a standard deviation equal to 0.27 .
} 
discrepancies were tightly distributed with a mean discrepancy of less than 6 basis points with a standard deviation of 0.097 . On the whole, our analyses of spread discrepancies stratified by age and by issuance size support the views of subordinated debt market participants who perceived that the most liquid banking organization bonds are those that have been recently issued and those that have a large issuance size. ${ }^{27}$

Even if discrepancies are large, it may be the case that spread data across vendor pricing sources are highly correlated. To see if this were the case, we calculated the correlation between sources for each bond in the sample and then stratified bonds by their age (less than 3 years since issuance, 3 to 5 years since issuance, more than 5 years since issuance) and by their issuance size (less than $\$ 150$ million, $\$ 150$ million to $\$ 300$ million, greater than $\$ 300$ million). The mean correlation for each of these age subgroups and for each of these issuance size subgroups are presented in table 1. As with spread discrepancies, a bond's age seems to matter for the correlation between spreads calculated from alternative bond pricing sources. The subsample of bonds that had been outstanding less than three years had the highest mean correlation $(0.71)$ among the three age subgroups. Moreover, a bond's issuance size seems to matter when it comes to either spread discrepancies or correlations in spreads across Bloomberg and IDC sources. The subsample for bonds with an issuance size greater than $\$ 300$ million had the highest mean correlation (0.87) among the issuance size subgroups. These findings suggest that Bloomberg and IDC price data are more consistent with one another for bonds that have been issued relatively recently and for bonds that are relatively large, both characteristics of bonds that are actively traded.

Of the 265 issues analyzed, 178 (67\%) were issued by bank holding companies that have at some point been classified by bank supervisors as large, complex, banking organizations (LCBOs). ${ }^{28}$ In general, LCBOs (1) have significant on- and off-balance sheet activities, (2) offer a broad range of products and services at the domestic and international levels, (3) participate

\footnotetext{
${ }^{27}$ See Board of Governors of the Federal Reserve System (1999) and Board of Governors of the Federal Reserve System and United States Department of the Treasury (2000).

${ }^{28}$ The supervisory criteria for the LCBO classification are discussed in DeFerrari and Palmer (2001, p.50) and Board of Governors of the Federal Reserve System (1999). Although the Federal Reserve does not publish a list of the names of all LCBOs, a partial list of LCBOs as of December 31, 1998 is contained in Board of Governors of the Federal Reserve System (1999). All 16 LCBOs in the sample (Bank of America, Bank One, Bank of New York, Chase Manhattan, Citicorp, First Union, Fleet Financial, JP Morgan, Keycorp, Mellon Financial, PNC, Republic New York, Suntrust, US Bank NA, Wachovia, and Wells Fargo) are on that list and were also among the 20 largest bank holding companies (ranked by total assets) during the sample period.
} 


\section{Table 1.}

Mean Correlations for Subordinated Debt Spreads Across Bloomberg and Interactive Data Corporation Data

Bonds Stratified by Issuer Cohort and by Instrument Characteristics

Weekly Data, January 1997 - October 1999

\begin{tabular}{|c|c|c|c|}
\hline $\begin{array}{l}\text { Issuer Cohort } \\
\text { Investment Characteristics }\end{array}$ & $\begin{array}{c}\text { Number of } \\
\text { Issues }\end{array}$ & $\begin{array}{c}\text { Percent of } \\
\text { Sample }\end{array}$ & $\begin{array}{c}\text { Mean } \\
\text { Correlation }\end{array}$ \\
\hline \multicolumn{4}{|l|}{ All 40 Bank } \\
\hline \multicolumn{4}{|l|}{ Age (i.e.,Time Since Issuance) } \\
\hline Less than 3 Years & 122 & 22.42 & 0.7142 \\
\hline 3 to 5 Years & 159 & 35.73 & 0.4961 \\
\hline Greater than 5 Years & 164 & 36.85 & 0.6818 \\
\hline \multicolumn{4}{|l|}{ Amount issued } \\
\hline Less than $\$ 150$ million & 56 & 21.13 & 0.7547 \\
\hline$\$ 150-\$ 300$ million & 148 & 55.85 & 0.8213 \\
\hline Greater than $\$ 300$ million & 61 & 23.02 & 0.8656 \\
\hline \multicolumn{4}{|l|}{ Large, Complex } \\
\hline \multicolumn{4}{|l|}{ Banking Organizations ${ }^{1}$} \\
\hline \multicolumn{4}{|l|}{ Age (i.e., Time Since Issuance) } \\
\hline Less than 3 Years & 86 & 28.86 & 0.7571 \\
\hline 3 to 5 Years & 107 & 35.91 & 0.5017 \\
\hline Greater than 5 Years & 105 & 35.23 & 0.7043 \\
\hline \multicolumn{4}{|l|}{ Amount issued } \\
\hline Less than $\$ 150$ million & 27 & 15.17 & 0.8044 \\
\hline$\$ 150-\$ 300$ million & 111 & 62.36 & 0.8359 \\
\hline Greater than $\$ 300$ million & 40 & 22.47 & 0.8614 \\
\hline
\end{tabular}

${ }^{1}$ Sixteen of the banking organizations in the 40 bank holding company cohort were classified by bank supervisors as large, complex banking organizations as of December 31, 1998 
extensively in large-value payment and settlement systems, and (4) are of substantial size. The correlations between Bloomberg and IDC spreads were on average higher for LCBOs (mean correlation of 0.84 ) than for other bank holding companies in our sample (mean correlation of 0.78). The higher correlations between Bloomberg and IDC spreads for LCBO bonds apparently were not driven by differences in issuance sizes or by less mature outstanding debt (table 1, bottom panel): LCBO bonds stratified into the three alternative age subgroups and into the three alternative issuance size subgroups had higher mean correlations than the respective subgroups for the 40 bank holding company sample (table 1, top panel). As with the larger sample, the LCBO mean correlations in spreads across sources are highest for the bonds that have been most recently issued and increase with issuance size. In fact, for recently issued LCBO bonds (outstanding less than 3 years) with large issuance size (greater than $\$ 300$ million) the mean correlation between spreads calculated from vendor price data was 0.82 . And, for bonds outstanding between 3 to 5 years in that issuance size subgroup, the mean correlation between spreads from alternative vendor data sources was only 0.44 .

Despite what appear to be low correlations in the subordinated debt spreads between the IDC and Bloomberg sources for each bond in the sample, there could be consistency across sources in identifying the groups of "most risky" and "least risky" banking organizations. Indeed, from the perspective of supervisory surveillance, such rankings, and changes therein, could be more important that absolute spreads, per se.

To test the robustness of rankings, we considered the ranking of each banking organization's minimum subordinated debt spread across all of their issues in the sample for the first week of January in years 1997, 1998, and 1999. Presumably, the issue with the minimum spread over a Treasury security with comparable maturity would be the one that was the most liquid for each banking organization. The rankings of these minimum spreads calculated from Bloomberg and IDC price data are reported in table 2 from the smallest to largest spread using the Bloomberg source for pricing data.

In January 1997, there is considerable agreement across sources on the rankings of minimum spreads. Of the 10 bank holding companies with the lowest spreads calculated from Bloomberg price data, 9 also had the lowest spreads calculated from IDC price data. And, 8 of the 10 sample bank holding companies with the highest spreads calculated from Bloomberg price data also were in the highest 10 spreads calculated from IDC price data. 
Table 2.

Rankings from Lowest to Highest Spread Value ${ }^{1}$

Minimum Spread Over Comparable Maturity Treasury Securities for Selected Subordinated Notes and Debentures Issued by Each Banking Organization Data Sources: Interactive Data Corporation (IDC) and Bloomberg

\begin{tabular}{|c|c|c|c|c|c|c|c|c|}
\hline Banking Organization Name & $\begin{array}{c}\text { Bloomberg } \\
\text { Rank }\end{array}$ & IDC Rank & Banking Organization Name & $\begin{array}{c}\text { Bloomberg } \\
\text { Rank }\end{array}$ & IDC Rank & Banking Organization Name & $\begin{array}{c}\text { Bloomberg } \\
\text { Rank }\end{array}$ & IDC Rank \\
\hline SUNTRUST BKS INC & 1 & 1 & SUNTRUST BKS INC & 1 & 1 & SUNTRUST BKS INC & 1 & 1 \\
\hline WACHOVIA CORP & 2 & 2 & CHASE MANHATTAN CORP & 2 & 5 & WACHOVIA CORP & 2 & 3 \\
\hline CHASE MANHATTAN CORP & 6 & 7 & BANKAMERICA CORP & 6 & 10 & AMSOUTH BANCORPORATION & 6 & 12 \\
\hline JPMORGAN \& CO INC & 7 & 8 & REPUBLIC NY CORP & 7 & 3 & REPUBLIC NY CORP & 7 & 34 \\
\hline FIRST CHICAGO CORP & 8 & 6 & BANK OF NEW YORK INC & 8 & 21 & BANKAMERICA CORP & 8 & 4 \\
\hline BANKAMERICA CORP & 9 & 10 & BANKERS TRUST CORP & 9 & 23 & BANK ONE CORP & 9 & 13 \\
\hline REPUBLIC NY CORP & 10 & 5 & SHAWMUT NATL CORP & 10 & 8 & FIRST CHICAGO CORP & 10 & 14 \\
\hline BANK ONE CORP & 11 & 15 & COMERICA INC & 11 & 20 & WELLS FARGO \& CO & 11 & 7 \\
\hline REGIONS FINL CORP & 12 & 36 & CITICORP & 12 & 4 & MELLON FINL CO & 12 & 6 \\
\hline NATIONSBANK CORP & 13 & 17 & JPMORGAN \& CO INC & 13 & 12 & SHAWMUT NATL CORP & 13 & 16 \\
\hline WELLS FARGO \& CO & 19 & 19 & FIRST INTERSTATE BANCORP & 19 & 31 & BANK OF AMERICA CORP & 19 & 38 \\
\hline BANK OF NEW YORK INC & 20 & 12 & FIRST CHICAGO CORP & 20 & 6 & COMERICA BANK & 20 & 17 \\
\hline FIRST INTERSTATE BANCORP & 21 & 26 & BANK ONE CORP & 21 & 34 & CRESTAR FINL CORP & 21 & 25 \\
\hline SECURITY PACIFIC CORP & 22 & 9 & FIRST MD BANCORP & 22 & 30 & PNC FUNDING CORP & 22 & 8 \\
\hline MELLON FINL CO & 23 & 14 & WELLS FARGO \& CO & 23 & 22 & HUNTINGTON NATL BANK & 23 & 11 \\
\hline COMERICA BANK & 24 & 20 & NCNB CORP & 24 & 16 & FIRST MD BANCORP & 24 & 27 \\
\hline COMERICA INC & 25 & 29 & CORESTATES CAPITAL CORP & 25 & 18 & CITICORP & 25 & 18 \\
\hline NCNB CORP & 26 & 18 & COMERICA BANK & 26 & 13 & REGIONS FINL CORP & 26 & 21 \\
\hline BANK OF AMERICA CORP & 27 & 37 & PNC FUNDING CORP & 27 & 17 & CORESTATES CAPITAL CORP & 27 & 28 \\
\hline FIRST MD BANCORP & 28 & 31 & HUNTINGTON NATL BANK & 28 & 24 & COMERICA INC & 28 & 36 \\
\hline CRESTAR FINL CORP & 29 & 33 & BANK OF AMERICA CORP & 29 & 33 & KEYCORP & 29 & 30 \\
\hline SOUTHTRUST CORP & 30 & 25 & CRESTAR FINL CORP & 30 & 15 & JPMORGAN \& CO INC & 30 & 9 \\
\hline SHAWMUT NATL CORP & 31 & 24 & BANK OF BOSTON CORP & 31 & 36 & FIRST OF AMERICA BANK CORP & 31 & 24 \\
\hline FIRST OF AMERICA BANK CORP & 32 & 28 & SOUTHTRUST CORP & 32 & 25 & US BANK NATL ASSN & 32 & 31 \\
\hline BANK OF BOSTON CORP & 33 & 30 & MERCANTILE BANCORP INC & 33 & 37 & BANK OF NEW YORK INC & 33 & 5 \\
\hline FLEET FINL GROUP INC & 34 & 27 & FLEET FINL GROUP INC & 34 & 29 & MERCANTILE BANCORP INC & 34 & 33 \\
\hline
\end{tabular}

${ }^{1}$ Banking organizations in each period are listed in the order of their Bloomberg rank. Names of banking organizations classified by bank supervisors as large, complex banking organizations as of December 31, 1998 are in upper case letters. Concordance in rankings between data sources are indicated with bold typeface. 
In January 1998, only 70 percent of the 10 lowest Bloomberg bank holding company spreads were also in the 10 lowest IDC bank holding company spreads, and only 60 percent of the 10 highest bank holding company Bloomberg spreads were also in the 10 highest bank holding company IDC spreads.

In January 1999, only 50 percent of the sample bank holding companies ranked in the top 10 (lowest spreads) and 60 percent of sample bank holding companies ranked in the bottom 10 (highest spreads) using Bloomberg price data were in the top 10 and bottom 10 using IDC price data, respectively. There was even one bank holding company (Republic New York Corp) that was ranked in the bottom $10\left(34^{\text {th }}\right)$ using IDC price data and in the top $10\left(7^{\text {th }}\right)$ using Bloomberg price data.

More formal tests of these relationships are given in table 3. Since both absolute rankings and relative movements in rankings of spreads across data sources may be important for supervisory surveillance purposes, Spearman and Kendall tau-b correlation coefficients were calculated to measure the association between the spreads calculated using Bloomberg and IDC pricing data sources. $^{29}$ The former measure is concerned with differences in absolute rankings, putting higher weight on spreads at the extremes, whereas the latter measure captures differences in relative rankings. Both Spearman and Kendall statistics, along with asymptotic standard errors are reported in table 3.

For the 40 bank holding company sample, both the Spearman and Kendall test statistics

\footnotetext{
${ }^{29}$ For Spearman and Kendall correlations, the data on random variables $x$ and $y$ are ranked. The Spearman correlation is computed on those ranks by using the formula for the Pearson correlation measure and by using averaged ranks in cases where there is a tie in the rankings. More formally, the formula for the Spearman correlation is:

$$
\theta=\frac{\sum\left(R_{i}-\bar{R}\right)\left(S_{i}-\bar{S}\right)}{\sqrt{\sum\left(R_{i}-\bar{R}\right)^{2}\left(S_{i}-\bar{S}\right)^{2}}}
$$

where $R_{i}$ is the rank of the $i$ th $x$ value, $S_{i}$ is the rank of the $i$ th $y$ value, and $\bar{R}$ and $\bar{S}$ are means of the $R_{i}$ and $S_{i}$ values, respectively.

To compute the Kendall correlation, observations are first ranked with respect to the $x$ variable, then they are ranked again according to the values of the $y$ variable. The formula for Kendall's tau-b is:

$$
\tau=\frac{\sum_{i<j} \operatorname{sgn}\left(B_{i}-B_{j}\right) \operatorname{sgn}\left(I_{i}-I_{j}\right)}{\sqrt{\left(T_{0}-T_{1}\right)\left(T_{0}-T_{2}\right)}}
$$

where $T_{0}$ equals $n(n-1) / 2, T_{1}$ equals $\sum t_{i}\left(t_{i}-1\right) / 2$, and $T_{2}$ equals $\sum u_{i}\left(u_{i}-1\right) / 2$. The $t_{i}\left(u_{i}\right)$ are the number of tied $x$ (respectively $y$ ) values in the $i$ th group of tied $x$ (respectively $y$ ) values, $n$ is the number of observations, and sgn $(z)$ equals one, if $z$ is greater than zero; $\operatorname{sgn}(z)$ equals zero, if $z$ is equal to zero; and, $\operatorname{sgn}(z)$ equals minus one, if $z$ is less than zero.
} 


\section{Table 3.}

\section{Are Ranks in Spreads Across Bloomberg and Interactive Data Corporation Sources Consistent with one Another?}

Correlation Coefficients for Minimum Spreads, Selected Weeks

\begin{tabular}{|c|c|c|c|}
\hline \multirow{2}{*}{$\begin{array}{c}\text { Issuer Cohort } \\
\text { Correlation } \\
\text { Coefficient }\end{array}$} & \multicolumn{3}{|c|}{ Date } \\
\hline & January 1997 & January 1998 & January 1999 \\
\hline \multicolumn{4}{|c|}{$\begin{array}{l}\text { All } 40 \text { Bank Holding } \\
\text { Companies }\end{array}$} \\
\hline Spearman & $\begin{array}{c}0.766 \\
(0.086)\end{array}$ & $\begin{array}{c}0.680 \\
(0.093)\end{array}$ & $\begin{array}{c}0.532 \\
(0.136)\end{array}$ \\
\hline Kendall tau- $b$ & $\begin{array}{c}0.601 \\
(0.082)\end{array}$ & $\begin{array}{c}0.501 \\
(0.088)\end{array}$ & $\begin{array}{c}0.409 \\
(0.109)\end{array}$ \\
\hline \multicolumn{4}{|c|}{$\begin{array}{l}\text { Large, Complex Banking } \\
\text { Organizations }{ }^{1}\end{array}$} \\
\hline Spearman & $\begin{array}{c}0.946 \\
(0.044)\end{array}$ & $\begin{array}{c}0.820 \\
(0.142)\end{array}$ & $\begin{array}{c}0.923 \\
(0.065)\end{array}$ \\
\hline Kendall tau- $b$ & $\begin{array}{c}0.848 \\
(0.078)\end{array}$ & $\begin{array}{c}0.714 \\
(0.160)\end{array}$ & $\begin{array}{c}0.802 \\
(0.095)\end{array}$ \\
\hline
\end{tabular}

${ }^{1}$ Sixteen of the banking organizations in the 40 bank holding company cohort were classified by bank supervisors as large, complex banking organizations as of December 31, 1998. 
reject the null hypothesis of independence in rankings at the 1 percent level for all three test dates (table 3, top panel). The Kendall rank correlations are high, but not as high as the Spearman correlations. The high Kendall correlations indicate a high degree of concordance between spread rankings; the coefficients are lower than Spearman coefficients because the spread rankings are not as consistent across Bloomberg and IDC sources for bank holding companies in the middle spread ranges for each of the three dates considered. The decline in both test statistics over the three dates suggests less concordance between spread rankings using Bloomberg and IDC price data in January 1999 than in January 1997. This decline in concordance may have resulted from a reduction in bond market liquidity after the market turmoil in August-October 1998.

If only the ranking of each LCBO's minimum subordinated debt spread across all of their sample bonds for the first week of January in years 1997, 1998, and 1999 are considered, then both Spearman and Kendall rank coefficients are very high and statistically significant for each date (table 3, bottom panel). As was the case in the top panel of table 2, lower Kendall correlation coefficients than Spearman correlation coefficients indicate that spread rankings are not as consistent across Bloomberg and IDC sources for LCBOs in the middle spread ranges as they are for LCBOs in the extreme tails of the spread distributions for each of the three dates considered. With regard to LCBOs in the extreme tails of the distribution, the Spearman coefficients indicate high correspondence in rankings across these data sources. For example, in January 1997, there was agreement about which LCBOs had the lowest three and highest three spreads. In January 1998, both Bloomberg and IDC agreed on two of the three LCBOs with the lowest spreads, and agreed on the three LCBOs with the highest spreads. And, in January 1999, these sources agreed on two of the three LCBOs with lowest spreads and hardly agreed at all about which LCBOs had the highest spreads.

Summing up our results thus far, there seems to be a greater degree of agreement about subordinated debt spreads calculated by using Bloomberg prices and by using IDC prices on larger issues, and/or issues that have been recently issued. This agreement is particularly strong for the largest and most recently issued subordinated bonds issued by LCBOs. In addition, there seems to be considerable agreement across sources in relative subordinated debt spreads such that rankings of bank holding companies by spreads are fairly consistent with one another, particularly for the "safest" and "most risky" bank holding companies. The concordance on 
rankings of spreads calculated using different vendor prices increases substantially when one only considers recently issued bonds by LCBOs. Since there are discrete gaps in the time series price data from both Bloomberg and IDC, neither data source would be preferred to the other because of coverage considerations. However, because Bloomberg terminals can be used to extract both IDC prices and Bloomberg prices, it should not be too surprising that there is considerable consistency in these two data sources. ${ }^{30}$

\section{COMPARING VENDOR AND DEALER DATA}

Next, spreads calculated using daily Bloomberg price data are compared with daily broker dealer spread data from Merrill Lynch and from Chase Securities. Merrill Lynch supplied data for 21 separate bonds issued by 18 bank holding companies for the January 1997 to December 1999 period. $^{31}$ In many cases, Merrill Lynch reported spreads on dates where Bloomberg had missing values for an issue's price. It is unclear, however, whether the bonds were actually traded on such dates or whether spreads were derived by the broker dealer using prices on similar bonds with matrix pricing methods. This suggests that broker dealer data could potentially be used to fill some of the time series gaps in vendor data. On dates where both Merrill Lynch and Bloomberg spreads can be compared, these spreads are visually quite similar. Indeed, statistical correlations between the Bloomberg and Merrill Lynch spreads for the 21 bond time series had a mean of 0.74 , with a range from 0.34 to 0.94 . For the 15 bonds issued by LCBOs, the correlations were on average higher (0.78). Thus, there is a considerable degree of consistency between spreads calculated from vendor price data and Merrill Lynch spreads.

Chase Securities spread data were also consistent with spreads that were calculated from Bloomberg price data. Chase Securities provided subordinated debt spreads on 13 bonds. ${ }^{32}$ For

\footnotetext{
${ }^{30}$ Historical Bloomberg price data can be obtained using a Bloomberg terminal, but historical IDC price data are available only through the vendor.

${ }^{31}$ Merrill Lynch subordinated debt spreads may not be strictly comparable to the spreads we calculated from Bloomberg data since Merrill Lynch may not have interpolated the Treasury yield curve in the same manner as we did. The 18 bank holding companies represented in the sample are BankAmerica Corp., BankBoston Corp., Bankers Trust Corp., Bank One Corp, Chase Manhattan Corp., Citigroup, Firstar Bank NA, First Union, Fleet Financial Group, JP Morgan \& Co., Key Bank NA, Mellon Bank NA, National City Corp., Northern Trust Corp., PNC Funding Corp., Republic New York Corp., US Bank NA, and Wachovia Corporation.

${ }^{32}$ The 13 bonds were issued by BankBoston, Chase Manhattan, Comerica, First Union National Bank, Fleet National Bank, JP Morgan and Company, Key Bank New York, Mellon Financial Corp, National City Corporation, PNC Funding Corp, Sun Trust, and Wachovia Corporation.
} 
10 of these 13 bonds, the correlation between spreads calculated from Bloomberg data and Chase Securities spreads was greater than 0.75. And, the mean correlation between such spreads across all 13 bonds was 0.78 . For the 10 bonds issued by LCBOs, the mean correlation between spreads calculated from Bloomberg price data and Chase Securities spreads was even higher at $0.81 .{ }^{33}$ In addition, although there appears to be a relatively high correlation between Bloomberg and Chase Securities data, this may not be the case for a larger sample of bonds. Each broker dealer provided time-series information only on those bonds for which they make markets and/or that they monitor closely. Thus, there was not much overlap in the spread data provided by the two broker dealers.

Subordinated debt spread data on only four bonds (issued by Comerica, JP Morgan, National City Corp, and Wachovia) were provided by both Merrill Lynch and Chase Securities. These spreads were compared to the spreads calculated using Bloomberg data. For all four bonds, there was a very high correlation between the spreads provided by the two broker dealers. These correlations were 0.92, 0.95, 0.97, and 0.97 for the bonds issued by Comerica, JP Morgan, National City Corp, and Wachovia, respectively. For two bonds (issued by Comerica and National City Corp.), the spreads we calculated from Bloomberg price data were more highly correlated with the spreads provided by Merrill Lynch. For the other two bonds (issued by JP Morgan and Wachovia), the spreads calculated from Bloomberg price data were more highly correlated with the spreads provided by Chase Securities.

\section{SUMMARY OF VENDOR - DEALER COMPARISONS}

In sum, it appears that broker dealer spread data are consistent with each other and are by and large consistent with vendor data. In addition, the data on subordinated notes and debentures spreads are most consistent across vendors for bond issues that are most liquid. Our analysis suggests that the liquidity of a bond depends on whether the issuer is an LCBO, its issuance size, the age of an issue, and on the overall liquidity of the bond market. Because spread data are most consistent across data sources for large, complex organization debt that has been outstanding less than three years and that has an issuance size greater than $\$ 150$ million,

\footnotetext{
${ }^{33}$ As was possible with the Merrill Lynch data, because Chase Securities may not have used the same methodology for calculating the yield on a Treasury security with comparable maturity for each bond as described above, some of the differences in spreads between sources may have resulted from term-structure changes over the sample period.
} 
this suggests that these criteria could be used by bank supervisors for selecting the subordinated debt issues that would be monitored closely.

Despite substantial differences in levels of spreads for individual bonds across vendors, there is a high degree of concordance in rankings of banking organizations by their minimum spread across issues. And, there is considerable agreement about which bank holding companies, or LCBOs, are at the extreme tails of the distribution of spreads. The more liquid the overall bond market, the more consistent are rankings in spreads across vendors. The concordance in rankings across data sources supports the view that there is information content in subordinated debt spreads that could be useful for supervisory surveillance purposes.

\section{Time Series Analyses Using Different Data Sources}

Recently, some subordinated debt proposals would require bank supervisors not only to monitor subordinated debt spreads, but also to use such spreads for timing the prompt regulatory actions that were established for undercapitalized banks under the Federal Deposit Insurance Corporation Improvement Act (FDICIA). ${ }^{34}$ The U.S. Shadow Financial Regulatory Committee, for example, would consider a bank "undercapitalized," if the yield on its subordinated debt rises above the yield of Baa-rated corporate bonds for three consecutive months. ${ }^{35}$ And, Evanoff and Wall would consider a bank to be "severely undercapitalized," if its subordinated debt trades at yields comparable to yields on junk bonds (defined as those bonds with a Ba rating or lower) for a period of two weeks or longer. ${ }^{36}$ Clearly, the architects of these proposals would consider it

\footnotetext{
${ }^{34}$ FDICIA requires the federal banking agencies to place each bank in one of five zones based on its regulatory capital position: (1) well capitalized, (2) adequately capitalized, (3) undercapitalized, (4) significantly undercapitalized, or (5) critically undercapitalized. Undercapitalized banks are subject to increasingly severe mandatory sanctions as their capital ratios deteriorate.
}

${ }^{35}$ See U.S. Shadow Financial Regulatory Committee (2000, p.53). Under FDICIA, an "undercapitalized bank" (1) may not pay dividends or management fees; (2) is subject to increased monitoring; (3) must implement an acceptable capital restoration plan; (4) must restrict its asset growth; (5) requires approval for acquisitions, branching, and new business lines; (6) may not issue brokered deposits; and, (7) has its access to the discount window restricted. Significantly and critically undercapitalized banks are subject to increasingly severe mandatory sanctions. See Jones and King (1995, p. 492).

${ }^{36}$ See Evanoff and Wall (2000a, p.45 and 2000b, p.32). Severely undercapitalized banks are not defined in FDICIA. However, under FDICIA, a "significantly undercapitalized bank" is subject to the provisions applicable to an undercapitalized bank as well as (1) restrictions on the compensation of senior officers; (2) a requirement to raise additional capital or be merged; and (3) a requirement to pay no higher deposit rates than those that prevail in the region. And, for a bank that is determined to be "critically undercapitalized," after 60 days, it can not make payments on its subordinated debt without approval; it must be placed in receivership within 90 days, unless such action would not achieve the purposes of prompt corrective action, or within one year, unless specific statutory 
appropriate for bank supervisors to monitor subordinated debt spreads on at least a monthly, or weekly, basis, respectively.

Interestingly, however, most researchers have only considered whether secondary subordinated debt market prices are sensitive to banking organization-specific risks at year-end. For example, studies by Avery, Belton, and Goldberg (1988), Flannery and Sorescu (1996), and Jagtiani, Kaufman and Lemieux (1998) analyzed whether year-end debt subordinated debenture spreads were sensitive to traditional accounting-based measures of risk. ${ }^{37}$ Likewise, studies that have used contingent claims valuation techniques on subordinated debt prices to derive banking organization-specific implied asset volatilities (e.g., Gorton and Santomero (1990) and Hassan, Karels, and Peterson (1993)) have only considered the risk sensitivity of those volatilities at year-end.

Only recently have researchers begun to consider the risk-sensitivity of higher frequency secondary subordinated debt market data for banking organizations data. For example, DeYoung, Flannery, Lang and Sorescu (2001) used subordinated debt spreads to ascertain whether the private information obtained by bank examiners at national banks affects current and subsequent quarter-end assessments of the parent bank holding company's financial condition by the market. ${ }^{38}$ They found that subordinated bond investors re-price such debt based on the likely regulatory actions implied by bank-specific supervisory ratings. Also using quarter-end data, Jagtiani and Lemieux (2000) established for a sample of five banks, which eventually failed during the 1980-1995 period, that the debt market required dramatically higher spreads on the debt outstanding by the respective parent bank holding company about 6 quarters prior to each

requirements are met; it may not without FDIC approval (1) undertake material transactions; (2) extend credit for highly leveraged transactions; (3) make material changes in accounting methods; (4) pay excessive compensation or bonuses; and, (5) pay interest on liabilities above prevailing market rates.

${ }^{37}$ Avery, Belton, and Goldberg (1988) and Flannery and Sorescu (1996) adjusted bond yields for the value of call options, when appropriate, but Jagtiani, Kaufman and Lemieux (1998) limited their sample to bonds without call, put, or convertibility features. See Board of Governors of the Federal Reserve System and United States Department of Treasury (2000, Appendix C) for a summary of empirical studies that consider the effectiveness of market discipline exerted by uninsured liabilities on banking organizations.

${ }^{38}$ Bond and stock market prices may also influence supervisors views on a banking organization's financial condition. See Board of Governors of the Federal Reserve System and United States Department of Treasury (2000, pp. 28-30) for a description of the current uses of subordinated debt market information by bank supervisors. 
failure. ${ }^{39}$ Focusing on the 1986-1995 period, Lang and Robertson (2000) studied 17 bank holding companies that had a month-end subordinated debt spread that crossed a 700 basis point threshold. ${ }^{40}$ For these holding companies, the duration of the threshold violation varied considerably with a minimum of just one month, a maximum of 29 months, and an average duration of nine months. ${ }^{41}$ For periods when a banking organization is in distress, Lang and Robertson provide intriguing evidence that suggests that there is considerable agreement between monthly equity market and monthly bond market signals of a firm's financial condition.

Looking beyond the research that has analyzed banking organization debt spreads, timeseries analyses of spreads between rates on corporate and government bonds suggest that such spreads contain a "risk premium" that compensates investors for systematic (i,e,, shared and thus undiversifiable) risk. ${ }^{42}$ That is, corporate bond spreads are related to systematic risk factors (e.g., excess stock returns) that influence returns on common stocks. Since these risk premiums have been estimated to vary across bonds of different maturity and different rating class, this suggests that there would not be a one-to-one mapping between corporate debt spreads and expected default losses. ${ }^{43}$ Consequently, if bank holding company subordinated debt spreads contain systematic risk premiums, then bank supervisors would need to adjust the spread calculated for a banking organization's bond by various "factor loadings," derived from estimated time-series

\footnotetext{
${ }^{39}$ The debt issues analyzed by Jagtiani and Lemieux were either senior debt issues or subordinated debt issues. This finding suggests that bond market spreads could be useful to bank supervisors as a warning signal from financial markets.

${ }^{40}$ Call option-adjusted spreads were used in the analysis. Such adjustments were made using the procedures described in Flannery and Sorescu (1996).

${ }^{41}$ In five of the 17 cases where a bank holding company subordinated debt spread crossed the 700 basis point threshold, the duration of the spread exceeding the threshold was less than three months. Among the 17 holding companies, five eventually failed, 11 others were acquired, and only one (Mellon Bank Corporation) remains active. Mellon Bank Corporation exceeded the 700 basis point threshold for only one month. See Lang and Robertson (2000, p.16).

${ }^{42}$ Elton, Gruber, Agrawal, and Mann (2001) have argued that there are at least two reasons why corporate bond spreads could move systematically with other assets in the market. First, expected default losses could be correlated with equity prices. That is, default losses could decline with a rise in stock prices and default losses could increase with a fall in stock prices. Second, the compensation for risk required in capital markets could change over time. If changes in the required compensation for risk affect both corporate and stock markets, then this would introduce a systematic effect.

${ }^{43}$ See Fama and French (1993) and Elton, Gruber, Agrawal, and Mann (2001).
} 
models, to infer the bond market's evaluation of its expected default loss. ${ }^{44}$ Indeed, crosssectional comparisons of banking organization spreads on subordinated bonds with significantly different maturity or rating class without such adjustments could potentially be misleading.

The foregoing discussion suggests that it is important to consider the components (i.e., expected default losses and systematic risk factors) that drive the time-series movements of debt spreads when designing a supervisory monitoring system. For example, if high frequency (e.g., weekly) data are statistically sensitive to banking organization-specific risks and are generally rational, then supervisors could potentially systematically incorporate such market information into their analyses and action plans on an almost real-time basis. If systematic risk factors are economically and statistically important, then it may be important to adjust spreads by factor loadings that vary by maturity and rating class before cross-sectional comparisons between banking organizations are made by bank supervisors. If the time-series data on the same instruments from alternative sources suggest different sensitivities to banking organizationspecific risk measures or to systematic risk factors, then it may be difficult to employ time-series econometric models for surveillance purposes. Moreover, if the sensitivity to systematic risk factors varies across data sources, then rankings of factor-adjusted spreads could differ across data sources even when there is concordance in unadjusted spreads across such sources.

For a proxy that would fluctuate over time with bond market participants' perceptions about expected default losses, we considered the empirical literature on the risk-sensitivity of banking organization subordinated debt spreads. Traditionally, banking studies have used various accounting-based risk measures (e.g., the ratio of non-accrual loans to total assets, the ratio of accruing loans past due 90 days or more to total assets, the ratio of other real estate owned to total assets) to proxy for a banking organization's ability to repay creditors out of its own resources. Since such proxies rely exclusively on Consolidated Financial Statements filed with the Federal Reserve Board by each U.S. bank holding company, they are only available on a quarter-end basis. ${ }^{45}$ Since the mid-1990s, however, it has become common practice to use

\footnotetext{
${ }^{44}$ Elton, Gruber, Agrawal and Mann (2001) estimate that less than 25 percent of corporate spot spreads can be explained by expected default losses. They also demonstrate that the sensitivity to factors commonly used to explain risk premiums in common stocks explains between 66 percent and 85 percent of the spread in corporate and government rates that is not explained by the difference in promised and expected payments and taxes.

${ }^{45}$ Each FR Y-9 report consolidates the parent corporation with all of its bank and non-bank subsidiaries.
} 
market leverage (i.e., the ratio of total (book) liabilities to (the market value of common stock plus the book value of preferred stock)) as a proxy for banking organization-specific default risk. ${ }^{46}$ This proxy evolves each day with the firm's common stock price and shifts with movements in its quarter-end balance sheet information. Market leverage has been shown to be positively related to banking organization subordinated debt spreads in the issuance market and in the secondary bond market at year-end. ${ }^{47}$ Because market leverage can be calculated on a weekly basis, we used this proxy for banking organization-specific risk to gauge bond market participants' perceptions about expected default losses. ${ }^{48}$

For systematic risk factors that would be likely to influence all banking organization bond spreads, we turned to the literature that has considered the time-series properties of corporate bond spreads. Fama and French (1993) identified a common risk in bond returns that arises from unexpected changes in the term structure of interest rates. ${ }^{49}$ Changes in term structure were calibrated here using weekly values for one-year and ten-year constant maturity Treasury bond rates. ${ }^{50}$ The one-year Treasury bond rate is meant to represent the general level of expected returns on bonds, while the ten-year Treasury bond rate represents deviations in expected returns due to shifts in interest rates. Because term-structure changes may also affect expected default losses for the debt of banking organizations with interest rate risk exposure, we expect term-structure factors to be significant for all firms, but to vary in magnitude across

${ }^{46}$ Flannery and Sorescu (1996, p.1358) argue that higher market leverage should raise default risk. Moreover, Fama and French (1993, pp. 7-8) indicate that firms with high market leverage (low stock price relative to book value) tend to have low earnings on assets, with low earnings persisting for at least five years before and five years after market leverage is measured. Conversely, firms with low market leverage (a high stock price relative to book value) typically have persistently high earnings.

${ }^{47}$ Flannery and Sorescu (1996) and Jagtiani, Kaufman, and Lemieux (2000), for example, have used market leverage variables in their analyses of secondary market subordinated debt spreads. And, Covitz, Hancock, and Kwast (2000) used a market leverage variable in their analysis of issuance spreads for banking organization subordinated notes and debentures.

${ }^{48}$ Weekly market leverage data was constructed from weekly averages for the common stock price observed for each banking organization.

${ }^{49}$ Fama and French (1993) use the difference between the monthly long-term government bond return and the one-month Treasury bill return measured at the end of the previous month to proxy for this factor. Their empirical findings suggest that term structure changes have systematically influenced both corporate bond returns and stock returns.

\footnotetext{
${ }^{50}$ Business weekly averages of daily constant maturity one-year and ten-year Treasury rates are used. These rates are for "on-the-run" securities.
} 
firms. Another systematic factor that has been shown to capture common variation in both stock returns and bond returns is the excess return on the market portfolio of stocks. ${ }^{51}$ Thus, in our study we used weekly excess stock returns constructed from the Center for Research in Security Prices' daily value-weighted return on NYSE, Amex, and Nasdaq stocks and daily one-month Treasury bill rates. ${ }^{52}$

\section{Specification of the Time-series Model}

Because it may take some time for the bond market to adjust to new information on a banking organization's financial condition and/or to systematic factors, we considered a timeseries model for subordinated debt spreads at each banking organization that included four lags of the dependent variable (i.e., the banking organization's own lagged subordinated debt spreads), the contemporaneous one-year Treasury yield with its four lags, the contemporaneous ten-year Treasury yield with its four lags, and the contemporaneous market excess return with its four lags. Of the 40 banking organizations considered above, some did not issue common stock that was traded on a U.S. exchange, which precluded constructing a market leverage variable for such organizations, while others did not have enough time-series information on the subordinated debt prices (reported on both Bloomberg and IDC over the January 1997 to October 1999 period) to estimate the specified model. For the remaining 23 banking organizations, parameter estimates for the time-series model are presented in Tables 4A and 4B.

The format of tables $4 \mathrm{~A}$ and $4 \mathrm{~B}$ is identical. At the top of each table, the names of each banking organization analyzed with the time-series model are indicated. Explanatory variables are indicated in the left column with the time period for each explanatory variable indicated in the adjacent column: 0 indicates a contemporaneous variable, -1 indicates a one-period lag of the variable, -2 indicates a two-period lag of the variable, and so on. Time-series model estimates obtained using IDC data are presented in rows labeled with an "I" in the third column from the left. Analogously, time-series estimates obtained using Bloomberg data on the same bonds for

\footnotetext{
${ }^{51}$ See Fama and French (1993, p.19) for a discussion about the role of stock market factors in explaining the common variation stock and bond returns. They defined monthly excess stock market returns (p.15) as the difference between the value-weighted percent return on stocks and the one-month Treasury bill rate. In addition, Elton, Gruber, Agrawal, and Mann (2001, pp. 270-272) discuss the relationships between corporate, industrial, and financial returns and stock market excess returns (over Treasury bills).

${ }^{52}$ The daily excess stock market return is calculated as the difference between the daily value-weighted return on NYSE, Amex, and Nasdaq stocks and the off-the-run one month Treasury return. The weekly excess stock market return is the business weekly average of daily excess stock market returns.
} 
the respective banking organization are presented in rows labeled with a " $\mathrm{B}$ " in the third column from the left. The remaining columns contain parameter estimates. Because there are a large number of estimates presented, the significance of each parameter estimate, with a five percent level of confidence, is indicated with an asterisk $(*)$ next to the parameter and also by the entry being left-justified within the column of placement. Statistically insignificant coefficients are right-justified within the column of placement.

Several interesting findings result from a comparison of the time-series parameter estimates with IDC data and with Bloomberg data. The first lag of the subordinated debt spread is almost always statistically significant and is usually of similar magnitude, regardless of data source. Second, there is less consistency across the models estimated with the alternative data sources for the remaining lags of subordinated debt spreads in the model. That is, different lags are statistically important when alternative data sources are used to estimate the model. Third, in many cases at least one of the market leverage variables for a banking organization is statistically significant, and these variables appear to be significant more often when IDC data is used than when Bloomberg data is used. In contrast, it appears that the parameter estimates for one-year and ten-year Treasury yields are more likely to be significant when Bloomberg data are used, than when IDC data are used to estimate the model. This suggests that Bloomberg spread data are more sensitive to term structure changes than are IDC data. Regardless of the data source, stock market excess returns appear to importantly influence some banking organization subordinated debt spreads (e.g., Bank America and Republic New York) more than other banking organization debt spreads (e.g., Bank of Boston and Regions Financial Corporation). 
Table 4A.

Parameter Estimates Using Alternative Data Souces ( $\mathrm{I}=$ Interactive Data Corporation, B $=$ Bloomberg $)^{1}$ Full Sample, No Restrictions on Age of Bonds or Issuance Size

\begin{tabular}{|c|c|c|c|c|c|c|c|c|c|c|c|c|c|}
\hline \multirow[b]{2}{*}{$\begin{array}{l}\text { Explanatory } \\
\text { Variables }\end{array}$} & \multirow[b]{2}{*}{$\begin{array}{l}\text { Time } \\
\text { Period }\end{array}$} & \multirow[b]{2}{*}{$\begin{array}{l}\text { Data } \\
\text { Source }\end{array}$} & \multicolumn{11}{|c|}{ Banking Organization Name } \\
\hline & & & Amsouth & \begin{tabular}{|l} 
Bank \\
America
\end{tabular} & \begin{tabular}{|l|l} 
Bank of \\
New York
\end{tabular} & $\begin{array}{l}\text { Bank of } \\
\text { Boston }\end{array}$ & Citicorp & Comerica & Chase & Fleet & $\begin{array}{l}\text { First } \\
\text { Union } \\
\end{array}$ & \begin{tabular}{|l} 
JP \\
Morgan \\
\end{tabular} & Keybank \\
\hline \multirow{5}{*}{$\begin{array}{l}\text { Subordinated Debt } \\
\text { Spreads }\end{array}$} & -1 & $\begin{array}{l}\text { I } \\
\text { B }\end{array}$ & $\begin{array}{l}0.81^{*} \\
0.92 *\end{array}$ & $\begin{array}{l}0.85^{*} \\
0.69^{*}\end{array}$ & $\begin{array}{l}0.89^{*} \\
0.91^{*}\end{array}$ & $\begin{array}{r}-0.74 \\
4.17\end{array}$ & $\begin{array}{l}0.71^{*} \\
0.60^{*}\end{array}$ & $\begin{array}{l}0.81^{*} \\
0.89^{*}\end{array}$ & $\begin{array}{l}0.67^{*} \\
0.74^{*}\end{array}$ & $\begin{array}{l}0.92^{*} \\
0.46^{*}\end{array}$ & $\begin{array}{l}0.79 * \\
0.64 *\end{array}$ & $\begin{array}{l}0.84^{*} \\
0.70^{*}\end{array}$ & $\begin{array}{l}0.71^{*} \\
0.91^{*}\end{array}$ \\
\hline & -2 & $\begin{array}{l}\text { I } \\
\text { B }\end{array}$ & $\begin{array}{l}0.10 \\
0.10\end{array}$ & $0.15^{-0.04}$ & $-0.03 *{ }^{-0.09}$ & $\begin{array}{l}-0.23 \\
-2.02\end{array}$ & $\mid \begin{array}{c}0.06 \\
0.12 *^{*}\end{array}$ & $0.16^{*}-0.05$ & $\left|\begin{array}{c}0.09 * \\
0.05\end{array}\right|$ & $\begin{array}{r}-0.14 \\
0.17 *\end{array}$ & $\begin{array}{r}0.00 \\
0.14^{*}\end{array}$ & $\begin{array}{r}-0.05 \\
0.04\end{array}$ & $\begin{array}{r}0.15 \\
-0.15\end{array}$ \\
\hline & \multirow{2}{*}{-3} & I & $0.29 *$ & $0.12 *$ & $0.10^{*}$ & -0.86 & $0.13^{*}$ & $0.22 *$ & $0.09^{*}$ & 0.06 & 0.04 & 0.06 & -0.07 \\
\hline & & B & -0.03 & $0.07 *$ & 0.06 & 5.35 & $0.12 *$ & -0.05 & $0.12^{*}$ & $0.19^{*}$ & $0.14^{*}$ & $0.13^{*}$ & $0.23 *$ \\
\hline & -4 & $\begin{array}{l}\text { I } \\
\text { B }\end{array}$ & \begin{tabular}{|c}
$-0.21 *$ \\
-0.01
\end{tabular} & $\begin{array}{l}0.05^{*} \\
0.08^{*}\end{array}$ & $\begin{array}{r}0.02 \\
-0.02\end{array}$ & $\begin{array}{r}0.11 \\
-0.89\end{array}$ & $\cos ^{0.05}$ & $\begin{array}{l}-0.01 \\
-0.03\end{array}$ & $\begin{array}{l}0.07^{*} \\
0.05^{*}\end{array}$ & $\begin{array}{l}0.12 \\
0.15\end{array}$ & $\begin{array}{r}0.14 * \\
0.05\end{array}$ & $\begin{array}{l}0.13^{*} \\
0.11^{*}\end{array}$ & ${ }^{0.22 *}-0.05$ \\
\hline \multirow{10}{*}{$\begin{array}{l}\text { Market Leverage } \\
\text { Ratios }\end{array}$} & \multirow[b]{2}{*}{0} & I & -0.01 & $0.03^{*}$ & -0.00 & 0.22 & $0.06^{*}$ & -0.03 & $0.03^{*}$ & -0.02 & $0.04^{*}$ & $-0.04^{*}$ & 0.04 \\
\hline & & B & -0.03 & $-0.02 *$ & 0.02 & 0.38 & $0.02 *$ & -0.04 & $0.02 *$ & $-0.05^{*}$ & 0.02 & -0.00 & -0.07 \\
\hline & \multirow{2}{*}{-1} & I & 0.03 & $-0.04 *$ & -0.01 & 0.42 & $-0.01 *$ & $0.09^{*}$ & -0.01 & $0.05^{*}$ & -0.01 & 0.01 & -0.08 \\
\hline & & B & $0.06^{*}$ & $0.02 *$ & 0.02 & -1.40 & $0.03^{*}$ & 0.04 & -0.01 & 0.03 & -0.00 & 0.00 & 0.09 \\
\hline & \multirow{2}{*}{-2} & I & -0.02 & $0.04 *$ & $0.12 *$ & -0.17 & $-0.04 *$ & $-0.12 *$ & $-0.06^{*}$ & $-0.08 *$ & $-0.05 *$ & $0.04 *$ & 0.01 \\
\hline & & B & -0.04 & -0.01 & $0.07 *$ & 0.32 & $-0.02 *$ & $-0.11 *$ & -0.01 & 0.04 & 0.01 & -0.01 & $0.12 *$ \\
\hline & \multirow{2}{*}{-3} & I & -0.01 & $-0.01 *$ & $-0.11^{*}$ & 0.42 & $-0.01 *$ & -0.02 & $0.06^{*}$ & $-0.15^{*}$ & 0.01 & -0.01 & -0.02 \\
\hline & & B & 0.04 & $0.02 *$ & $-0.08 *$ & -0.63 & 0.10 & 0.02 & $0.03 *$ & -0.02 & $-0.04 *$ & 0.02 & $-0.21 *$ \\
\hline & \multirow{2}{*}{-4} & I & 0.01 & $-0.01 *$ & -0.03 & -0.71 & 0.00 & $0.07 *$ & $-0.03 *$ & $0.17 *$ & 0.01 & 0.00 & 0.06 \\
\hline & & B & -0.05 & $-0.01 *$ & $-0.05^{*}$ & -0.20 & $-0.02 *$ & $0.08^{*}$ & $-0.02 *$ & -0.06 & $0.03^{*}$ & 0.00 & $0.07 *$ \\
\hline \multirow{10}{*}{$\begin{array}{l}\text { One Year Treasury } \\
\text { Rates }\end{array}$} & 0 & I & 0.11 & $-0.17^{*}$ & $-0.20^{*}$ & -1.41 & $0.10^{*}$ & $-0.21^{*}$ & $-0.25^{*}$ & $-0.16^{*}$ & $-0.11^{*}$ & $-0.22^{*}$ & -0.13 \\
\hline & 0 & B & $0.27^{*}$ & $-0.07 *$ & 0.00 & 1.20 & -0.07 & $-0.32 *$ & $-0.37 *$ & $-0.28 *$ & $0.15^{*}$ & -0.09 & $-0.13 *$ \\
\hline & -1 & I & 0.07 & 0.05 & $0.11^{*}$ & -0.57 & -0.01 & $0.22^{*}$ & 0.09 & 0.04 & $0.10^{*}$ & $0.16^{*}$ & 0.02 \\
\hline & -1 & B & -0.15 & $-0.15^{*}$ & -0.04 & -4.47 & -0.05 & $0.26^{*}$ & $0.11^{*}$ & 0.05 & $-0.22 *$ & -0.06 & 0.16 \\
\hline & -2 & I & -0.21 & 0.02 & $-0.10^{*}$ & -0.21 & $-0.35^{*}$ & -0.06 & 0.11 & -0.13 & 0.00 & 0.00 & 0.03 \\
\hline & -2 & B & -0.21 & $0.14^{*}$ & $-0.10^{*}$ & 6.38 & 0.07 & 0.09 & $0.20 *$ & $0.31^{*}$ & $0.30^{*}$ & $0.16^{*}$ & 0.03 \\
\hline & & I & -0.21 & 0.04 & $0.18^{*}$ & 1.23 & 0.04 & -0.04 & -0.04 & 0.21 & 0.01 & 0.03 & 0.08 \\
\hline & -3 & B & -0.06 & $-0.07 *$ & $0.11^{*}$ & -5.60 & $-0.17 *$ & $-0.13 *$ & $-0.18^{*}$ & $-0.27^{*}$ & $-0.11^{*}$ & $-0.23 *$ & -0.14 \\
\hline & -4 & I & $0.21^{*}$ & 0.03 & -0.04 & -1.88 & $0.18^{*}$ & 0.03 & 0.05 & -0.01 & 0.02 & 0.04 & 0.04 \\
\hline & -4 & B & 0.14 & $0.12^{*}$ & -0.03 & 3.56 & 0.06 & 0.05 & $0.20^{*}$ & 0.12 & $0.12 *$ & $0.16^{*}$ & 0.05 \\
\hline & 0 & I & $-0.32^{*}$ & $-0.05^{*}$ & -0.01 & 1.13 & $-0.12^{*}$ & -0.02 & $-0.10^{*}$ & 0.03 & $-0.05^{*}$ & 0.00 & -0.02 \\
\hline & 0 & B & $-0.37 *$ & $-0.09 *$ & $-0.08 *$ & 0.73 & -0.01 & $0.08^{*}$ & $0.09^{*}$ & 0.12 & $-0.08^{*}$ & -0.02 & 0.03 \\
\hline & -1 & I & 0.17 & $0.05^{*}$ & 0.02 & -0.72 & -0.00 & -0.09 & $0.09^{*}$ & -0.03 & -0.02 & -0.08 & 0.06 \\
\hline & & B & $.29^{*}$ & $0.17^{*}$ & 0.04 & 4.66 & -0.02 & -0.08 & 0.02 & -0.03 & $0.25^{*}$ & 0.04 & -0.13 \\
\hline Ten Year Treasury & 2 & I & 0.17 & 0.03 & 0.04 & -1.16 & $0.19^{*}$ & 0.09 & -0.04 & $0.17 *$ & 0.02 & 0.01 & -0.09 \\
\hline Rates & -2 & B & 0.23 & $-0.07 *$ & 0.04 & -6.84 & 0.01 & -0.04 & $-0.11 *$ & $-0.26^{*}$ & $-0.20^{*}$ & $-0.15^{*}$ & -0.00 \\
\hline & -3 & I & $0.24 *$ & $-0.07 *$ & $-0.11 *$ & -0.19 & -0.01 & 0.03 & 0.01 & -0.15 & 0.00 & -0.05 & -0.03 \\
\hline & 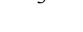 & B & -0.11 & $0.06^{*}$ & -0.04 & 4.30 & 0.06 & 0.08 & $0.13^{*}$ & $0.34 *$ & $0.14 *$ & $0.22 *$ & 0.13 \\
\hline & -4 & I & $-0.24 *$ & $0.06^{*}$ & $0.09^{*}$ & 1.96 & $-0.06^{*}$ & 0.00 & 0.04 & 0.03 & 0.04 & $0.11^{*}$ & 0.05 \\
\hline & -4 & B & -0.03 & -0.04 & $0.06^{*}$ & -2.34 & -0.00 & 0.02 & $-0.10 *$ & -0.94 & $-0.10^{*}$ & -0.06 & -0.01 \\
\hline & & I & -0.83 & $-2.20^{*}$ & -0.35 & 9.16 & 0.44 & $-1.91^{*}$ & 0.3 & $-7.26^{*}$ & -0.87 & $-6.20^{*}$ & -2.26 \\
\hline & 0 & B & $-3.81 *$ & $-1.67 *$ & -0.51 & -29.55 & -0.83 & $-1.80^{*}$ & 0.19 & -1.16 & -0.20 & $-3.62 *$ & $-4.14 *$ \\
\hline & -1 & I & -1.52 & $-2.61^{*}$ & 0.23 & 51.32 & $-1.16^{*}$ & -0.29 & -1.34 & 0.30 & $-1.38^{*}$ & $-4.42 *$ & -2.07 \\
\hline & -1 & B & -2.29 & $-2.25^{*}$ & $1.41^{*}$ & -61.58 & $-2.16^{*}$ & $-1.58^{*}$ & $-4.13^{*}$ & $-2.99 *$ & $-2.79 *$ & $-5.10^{*}$ & -2.54 \\
\hline Stock Market & -2 & I & 0.82 & 1.57 & 0.61 & 26.04 & 1.03 & $-1.83^{*}$ & $-1.57^{*}$ & 0.45 & 0.28 & 1.20 & -0.06 \\
\hline Excess Returns & -2 & B & 0.86 & -2.54 & -0.49 & -36.39 & $-2.11^{*}$ & $-3.22 *$ & $-2.52 *$ & $-3.04 *$ & $-2.34 *$ & $-4.05 *$ & $2.88^{*}$ \\
\hline & -3 & I & -0.22 & -0.02 & -1.05 & 27.44 & -0.35 & $-1.52 *$ & -0.48 & $-3.68 *$ & -0.23 & -1.59 & -1.18 \\
\hline & -3 & B & -1.32 & $0.08^{*}$ & 0.77 & -39.61 & 0.04 & -0.81 & 0.86 & -1.28 & -0.90 & -1.39 & $-4.94 *$ \\
\hline & -4 & I & 0.55 & $-1.67 *$ & -0.85 & -1.73 & $-1.17^{*}$ & 0.83 & $-2.29^{*}$ & -1.06 & $-1.42 *$ & $-1.87 *$ & -1.30 \\
\hline & -4 & $\mathrm{~B}$ & -0.13 & $-1.37 *$ & -0.79 & -65.97 & -0.49 & -0.08 & $-0.98^{*}$ & -1.73 & $-1.92 *$ & -1.63 & $-2.71 *$ \\
\hline$R^{2}$ & & I & 0.972 & 0.943 & 0.926 & 0.936 & 0.950 & 0.965 & 0.890 & 0.926 & 0.957 & 0.955 & 0.924 \\
\hline $\mathrm{R}^{-}$ & & $\mathrm{B}$ & 0.958 & 0.932 & 0.950 & 0.985 & 0.943 & 0.966 & 0.922 & 0.908 & 0.938 & 0.938 & 0.940 \\
\hline $\begin{array}{l}\text { F Test Statistic for } \\
\text { Equal Variances of } \\
\text { Error Terms }\end{array}$ & & & 0.747 & 0.893 & 1.169 & 5.746 & 0.941 & 1.306 & 1.529 & 0.876 & 0.738 & 0.753 & 1.109 \\
\hline Lower Bound, K1 & & & 1.393 & 1.072 & 1.141 & 2.194 & 1.105 & 1.184 & 1.091 & 1.274 & 1.116 & 1.153 & 1.296 \\
\hline Upper Bound, K2 & & & 1.393 & 1.072 & 1.141 & 2.194 & 1.105 & 1.184 & 1.091 & 1.274 & 1.116 & 1.153 & 1.296 \\
\hline
\end{tabular}


Table 4B.

Parameter Estimates Using Alternative Data Souces $(\mathrm{I}=$ Interactive Data Corporation, $\mathrm{B}=\mathrm{Bloomberg}){ }^{1}$ Full Sample, No Restrictions on Age of Bonds or Issuance Size

\begin{tabular}{|c|c|c|c|c|c|c|c|c|c|c|c|c|c|c|}
\hline \multirow[b]{2}{*}{$\begin{array}{l}\text { Explanatory } \\
\text { Variables }\end{array}$} & \multirow[b]{2}{*}{$\begin{array}{l}\text { Time } \\
\text { Period }\end{array}$} & \multirow[b]{2}{*}{$\begin{array}{l}\text { Data } \\
\text { Source }\end{array}$} & \multicolumn{12}{|c|}{ Banking Organization Name } \\
\hline & & & Mellon & $\begin{array}{l}\text { First Amer } \\
\text { Bk Corp } \\
\end{array}$ & Banc One & PNC & \begin{tabular}{|l} 
Regions \\
Financial \\
Corporation
\end{tabular} & $\begin{array}{l}\text { Republic } \\
\text { New York }\end{array}$ & Southtrust & Suntrust & \begin{tabular}{|l} 
Union \\
Planters
\end{tabular} & $\begin{array}{l}\text { US Bank } \\
\text { NA }\end{array}$ & Wachovia & $\begin{array}{l}\text { Wells } \\
\text { Fargo }\end{array}$ \\
\hline \multirow{8}{*}{$\begin{array}{l}\text { Subordinated Debt } \\
\text { Spreads }\end{array}$} & -1 & I & $0.73^{*}$ & $0.68^{*}$ & $0.71^{*}$ & $0.78^{*}$ & $0.49^{*}$ & $0.73^{*}$ & $0.70^{*}$ & $0.79^{*}$ & 0.69 & $0.84^{*}$ & $0.71^{*}$ & $0.71^{*}$ \\
\hline & & B & $0.64^{*}$ & $0.78^{*}$ & $0.65 *$ & $0.66^{*}$ & $0.85^{*}$ & $0.87 *$ & $0.78^{*}$ & $0.79 *$ & 0.28 & $0.56^{*}$ & $0.62^{*}$ & $0.72 *$ \\
\hline & -2 & I & 0.05 & 0.17 & $0.11 *$ & 0.10 & 0.12 & $0.10^{*}$ & -0.02 & $0.20 *$ & 0.21 & 0.22 & $0.28 *$ & 0.11 \\
\hline & & B & $0.21 *$ & $0.31 *$ & $0.23 *$ & $0.23^{*}$ & 0.20 & 0.05 & 0.18 & $0.20 *$ & 0.06 & -0.08 & $0.19 *$ & $0.14 *$ \\
\hline & -3 & I & 0.07 & 0.10 & 0.03 & 0.17 & 0.19 & $0.13 *$ & 0.07 & -0.03 & 0.05 & -0.26 & -0.03 & 0.07 \\
\hline & & B & 0.13 & -0.06 & 0.03 & 0.12 & 0.13 & -0.02 & 0.02 & 0.03 & $0.56^{*}$ & $0.33^{*}$ & 0.11 & 0.03 \\
\hline & -4 & I & $0.13^{*}$ & -0.06 & $6.13^{*}$ & -0.13 & -0.03 & 0.01 & 0.22 & 0.05 & -0.02 & 0.16 & 0.02 & 0.06 \\
\hline & & B & $\begin{array}{r}-0.02 \\
\end{array}$ & -0.12 & $2 \quad 0.07$ & -0.08 & $-0.29 *$ & 0.03 & -0.06 & -0.01 & 0.04 & 0.12 & 0.07 & 0.03 \\
\hline \multirow{10}{*}{$\begin{array}{l}\text { Market Leverage } \\
\text { Ratios }\end{array}$} & 0 & I & $0.19^{*}$ & $0.10^{*}$ & $0.08^{*}$ & 0.08 & 0.04 & $0.04 *$ & -0.01 & $0.18^{*}$ & 0.09 & -0.09 & $-0.07^{*}$ & $0.04^{*}$ \\
\hline & & B & $0.12 *$ & 0.05 & $0.02 *$ & -0.01 & 0.08 & $0.06^{*}$ & -0.02 & $0.06 *$ & -0.06 & -0.05 & -0.00 & -0.01 \\
\hline & -1 & I & $-0.21^{*}$ & -0.09 & -0.00 & 0.01 & -0.08 & $-0.03 *$ & 0.04 & $-0.17^{*}$ & -0.09 & $0.18^{*}$ & $0.12 *$ & -0.01 \\
\hline & & B & -0.05 & 0.05 & $0.04 *$ & $0.11^{*}$ & -0.07 & $7-0.06 *$ & 0.05 & -0.04 & 0.04 & 0.17 & 0.05 & 0.01 \\
\hline & -2 & I & -0.04 & 0.03 & $-0.10^{*}$ & $-0.12 *$ & -0.02 & 0.01 & -0.11 & $-0.07 *$ & -0.02 & $-0.22 *$ & $-0.10^{*}$ & $-0.04 *$ \\
\hline & & B & -0.06 & -0.08 & $8.06 *$ & -0.09 & -0.03 & 0.01 & 0.02 & -0.02 & 0.09 & $-0.39 *$ & $-0.10^{*}$ & -0.00 \\
\hline & -3 & I & -0.09 & -0.09 & -0.01 & 0.11 & 0.08 & -0.02 & $0.18^{*}$ & $0.06 *$ & 0.04 & 0.08 & 0.02 & -0.01 \\
\hline & & B & 0.03 & -0.06 & 0.01 & $-0.12 *$ & 0.12 & -0.02 & 0.06 & 0.01 & -0.00 & 0.18 & 0.03 & -0.03 \\
\hline & -4 & I & $0.14^{*}$ & 0.06 & 0.01 & $-0.09 *$ & -0.01 & -0.00 & -0.08 & -0.02 & -0.01 & 0.01 & 0.02 & 0.02 \\
\hline & & B & -0.04 & 0.05 & $-0.04 *$ & 0.08 & -0.08 & 0.01 & $-0.10^{*}$ & -0.02 & -0.05 & 0.02 & 0.01 & 0.03 \\
\hline \multirow{10}{*}{$\begin{array}{l}\text { One Year Treasury } \\
\text { Rates }\end{array}$} & 0 & I & $-0.15^{*}$ & 0.16 & 0.02 & -0.09 & -0.06 & $0.20^{*}$ & 0.07 & 0.11 & 0.19 & $-0.55^{*}$ & 0.09 & $-0.13^{*}$ \\
\hline & & B & -0.1 & 0.19 & 0.01 & -0.05 & -0.03 & -0.00 & $0.16^{*}$ & 0.05 & -0.27 & $-0.26^{*}$ & 0.05 & 0.03 \\
\hline & -1 & I & $0.16^{*}$ & 0.06 & 0.00 & $0.20^{*}$ & 0.02 & -0.05 & -0.10 & 0.04 & -0.06 & $0.74 *$ & 0.04 & $0.14^{*}$ \\
\hline & & B & $0.15^{*}$ & -0.08 & -0.00 & 0.08 & -0.06 & -0.02 & -0.04 & -0.01 & -0.11 & $0.46^{*}$ & -0.01 & $-0.19^{*}$ \\
\hline & -2 & I & -0.09 & $-0.28^{*}$ & $-0.17^{*}$ & -0.01 & 0.07 & $-0.15^{*}$ & 0.03 & $-0.19^{*}$ & -0.20 & -0.17 & -0.13 & 0.02 \\
\hline & & B & $-0.25^{*}$ & $-0.35 *$ & -0.08 & -0.08 & 0.09 & -0.08 & -0.09 & -0.00 & 0.31 & -0.08 & 0.04 & 0.09 \\
\hline & -3 & 1 & -0.04 & -0.11 & -0.07 & -0.19 & -0.08 & $-0.14^{*}$ & 0.08 & -0.01 & -0.27 & $-0.39^{*}$ & -0.10 & -0.10 \\
\hline & & B & -0.06 & 0.09 & $-0.13^{*}$ & $-0.34 *$ & -0.02 & $0.14^{*}$ & 0.00 & -0.12 & 0.00 & $-0.35^{*}$ & $-0.21 *$ & -0.08 \\
\hline & -4 & I & 0.08 & 0.02 & $0.19 *$ & 0.02 & -0.02 & $0.09 *$ & -0.07 & 0.06 & 0.26 & 0.18 & 0.08 & 0.05 \\
\hline & & B & $0.20^{*}$ & 0.08 & $0.16^{*}$ & $0.32 *$ & -0.07 & $-0.15^{*}$ & -0.05 & 0.08 & 0.01 & $0.30^{*}$ & 0.11 & 0.10 \\
\hline \multirow{10}{*}{$\begin{array}{l}\text { Ten Year Treasury } \\
\text { Rates }\end{array}$} & 0 & $I$ & -0.03 & $-0.19^{*}$ & -0.00 & 0.09 & -0.05 & $-0.20^{*}$ & -0.11 & $-0.26^{*}$ & $-0.31^{*}$ & $0.31^{*}$ & $-0.16^{*}$ & 0.00 \\
\hline & & B & -0.05 & -0.12 & -0.01 & 0.04 & 0.03 & $-0.13^{*}$ & $-0.13^{*}$ & -0.15 & 0.19 & $0.24 *$ & $-0.17^{*}$ & -0.02 \\
\hline & -1 & I & -0.07 & 0.04 & -0.03 & $-0.21 *$ & 0.07 & $0.07 *$ & 0.17 & 0.11 & 0.11 & $-0.37^{*}$ & 0.02 & -0.06 \\
\hline & & B & -0.08 & 0.01 & -0.03 & -0.08 & -0.07 & $0.14 *$ & -0.00 & 0.04 & -0.03 & $-0.42 *$ & 0.11 & 0.05 \\
\hline & -2 & I & 0.09 & 0.13 & $0.14 *$ & -0.03 & -0.08 & $0.08 *$ & -0.15 & $0.18^{*}$ & 0.19 & 0.04 & $0.16^{*}$ & 0.02 \\
\hline & & B & $0.19^{*}$ & $0.23 *$ & 0.07 & 0.07 & -0.02 & -0.00 & 0.11 & 0.10 & $-0.42^{*}$ & 0.11 & 0.01 & -0.03 \\
\hline & -3 & I & -0.00 & 0.09 & 0.02 & 0.10 & 0.01 & -0.01 & -0.09 & -0.05 & 0.20 & $0.37^{*}$ & 0.04 & 0.03 \\
\hline & & B & 0.11 & -0.07 & $70.12 *$ & $0.19^{*}$ & 0.00 & $-0.09 *$ & -0.01 & 0.06 & 0.09 & $0.29^{*}$ & $0.13^{*}$ & 0.08 \\
\hline & -4 & I & 0.03 & -0.02 & $-0.10^{*}$ & 0.07 & 0.07 & 0.05 & 0.14 & 0.00 & -0.15 & $-0.19^{*}$ & -0.05 & 0.01 \\
\hline & & B & $-0.15^{*}$ & -0.03 & $3-0.12 *$ & $-0.18^{*}$ & 0.09 & $0.13^{*}$ & 0.01 & -0.06 & 0.17 & $-0.24 *$ & -0.06 & -0.06 \\
\hline \multirow{10}{*}{$\begin{array}{l}\text { Stock Market } \\
\text { Excess Returns }\end{array}$} & 0 & I & $\begin{array}{l}-0.76 \\
\end{array}$ & 0.63 & -0.04 & -0.39 & -0.39 & 0.83 & -1.29 & $3.53 *$ & -0.67 & $-3.47^{*}$ & $-3.86^{*}$ & $-1.80^{*}$ \\
\hline & & B & -1.49 & -0.68 & -0.64 & -1.90 & 1.05 & 0.71 & $-3.68^{*}$ & -0.27 & -1.09 & -2.09 & -1.44 & $-1.59^{*}$ \\
\hline & -1 & I & $-3.57 *$ & -2.10 & $-2.10^{*}$ & -2.48 & -0.85 & $-1.28^{*}$ & 1.52 & -1.41 & 0.28 & 1.46 & -1.47 & $-2.10^{*}$ \\
\hline & & B & $-2.14^{*}$ & -1.29 & $9-1.45^{*}$ & -0.11 & -2.24 & $-2.67^{*}$ & -1.45 & $-2.39^{*}$ & -4.14 & 2.07 & -1.63 & -1.24 \\
\hline & -2 & I & -0.82 & 0.86 & 0.62 & -2.82 & 0.69 & $1.83^{*}$ & $-3.49^{*}$ & -1.02 & -0.96 & -3.01 & -1.64 & 0.10 \\
\hline & & B & -1.81 & -0.77 & $7-1.35^{*}$ & -0.84 & -1.97 & -0.16 & -0.38 & -0.02 & -1.57 & $-5.83^{*}$ & $-3.34 *$ & $-1.53^{*}$ \\
\hline & -3 & I & -0.28 & 0.51 & -0.62 & 2.05 & 1.07 & $2.96^{*}$ & 0.23 & -0.5 & 1.23 & 1.46 & 0.65 & -0.74 \\
\hline & & B & -0.19 & -0.64 & -1.16 & $-4.43 *$ & 0.88 & -0.99 & 0.10 & -1.37 & $7-5.59^{*}$ & -2.62 & -0.56 & $-2.08^{*}$ \\
\hline & -4 & I & -0.41 & 0.32 & $-3.17 *$ & -0.84 & -1.57 & $-1.89 *$ & -1.44 & 1.09 & -0.95 & $-4.53 *$ & -0.67 & $-1.72 *$ \\
\hline & & $\mathrm{B}$ & -0.08 & -0.95 & $5-2.17 *$ & -2.17 & -0.14 & $-2.22 *$ & -1.20 & -0.18 & -3.68 & $-6.22 *$ & -1.08 & $-2.11 *$ \\
\hline \multirow{2}{*}{$\mathrm{R}^{2}$} & & I & 0.929 & 0.959 & 0.950 & 0.931 & 0.726 & 0.946 & 0.802 & 0.984 & 0.941 & 0.976 & 0.959 & 0.921 \\
\hline & & $\mathrm{B}$ & 0.925 & 0.937 & 0.947 & 0.937 & 0.972 & 0.912 & 0.964 & 0.991 & 0.933 & 0.973 & 0.957 & 0.913 \\
\hline $\begin{array}{l}\text { F Test Statistic for } \\
\text { Equal Variances of } \\
\text { Error Terms }\end{array}$ & & & 1.058 & 0.923 & 1.005 & 0.990 & 1.423 & 0.586 & 2.480 & 1.529 & 0.854 & 0.766 & 0.952 & 0.952 \\
\hline Lower Bound, K1 & & & 1.229 & 1.405 & 1.164 & 1.317 & 1.456 & 1.132 & 1.302 & 1.302 & 1.431 & 1.559 & 1.222 & 1.185 \\
\hline Upper Bound, K2 & & & 1.229 & 1.405 & 1.164 & 1.317 & 1.456 & 1.132 & 1.302 & 1.302 & 1.431 & 1.559 & 1.222 & 1.185 \\
\hline
\end{tabular}


Interestingly, the variance of the error terms for the time-series model estimated with IDC data is statistically different from the variance of the error terms for the time-series model estimated with Bloomberg data for virtually all of the banking organizations analyzed in tables 4A and 4B. The statistic $\left.\left(n_{B}-1\right) \sum\left(X_{I i}-\bar{X}_{I}\right)^{2} /\left(n_{I}-1\right) \sum X_{B i}-\bar{X}_{B}\right)^{2}$, where $\mathrm{X}_{\mathrm{I}}$ and $\mathrm{X}_{\mathrm{B}}$ are error terms for the IDC and Bloomberg models estimated with $n_{I}$ and $n_{B}$ observations respectively, has an F distribution with $n_{I}-1$ and $n_{B}-1$ degrees of freedom when the variances for $X_{I}\left(\sigma_{I}\right)$ and $X_{B}\left(\sigma_{B}\right)$ are equal. ${ }^{53}$ The hypothesis that the variances of the error terms are equal is rejected when this $\mathrm{F}$ test statistic is outside of lower $\left(K_{1}\right)$ and upper $\left(K_{2}\right)$ bounds determined by the quantiles of the $\mathrm{F}$ distribution associated with the chosen critical values for a two-tailed test (typically, $\alpha / 2)$. In the bottom panels of tables $4 \mathrm{~A}$ and $4 \mathrm{~B}$, these $\mathrm{F}$ test statistics are presented with their upper and lower bounds for an equally distributed 0.05 critical value $(\alpha)$. An F test statistic smaller than the lower bound implies that there is more unexplained variance in the errors for the time series model estimated with Bloomberg data than when IDC data is used. Conversely, an F test statistic greater than the upper bound implies that there is more unexplained variance in the errors for the time series model estimated with IDC data than when Bloomberg data is used. For 17 of the 23 banking organizations, the $\mathrm{F}$ test statistic for equal variance of the error terms was less than the lower bound (indicated in the bottom row of tables 4A and 4B). The larger unexplained variance for the time-series model estimated with Bloomberg data than with IDC data is consistent with our observation that the discrepancies between Bloomberg and IDC banking organization subordinated debenture spreads are on average positive and are not normally distributed.

If only recently issued bonds (i.e., those outstanding 3 years or less) with issue sizes greater than 150 million dollars are considered, then the lack of consistency across the timeseries models estimated with the alternative data sources remains. The parameter estimates for the time series model estimated using IDC data and Bloomberg data on this more restrictive set of bonds are presented in tables $5 \mathrm{~A}$ and $5 \mathrm{~B}$, which have the same format as tables $4 \mathrm{~A}$ and $4 \mathrm{~B}$. Not surprisingly, fewer banking organizations had sufficient time-series data on subordinated

\footnotetext{
${ }^{53}$ See Mood, Graybill, and Boes (1974, pp. 438-440.) This test assumes that $X_{11}, \ldots, X_{\text {InI }}$ is a random sample from a normal density with a mean $\mu_{\mathrm{I}}$ and variance $\sigma_{\mathrm{I}} ; \mathrm{X}_{\mathrm{B} 1}, \ldots, \mathrm{X}_{\mathrm{BnB}}$ is a random sample from a normal density with a mean $\mu_{\mathrm{B}}$ and variance $\sigma_{\mathrm{B}}$; and, the two samples are independent.
} 
debt spreads during the sample period to estimate the model with restrictions on the age of the bonds and issuance size in place. As with the full sample, the parameter estimate for the first lag of the subordinated debt spread is almost always statistically significant at the five percent level of confidence and is usually of a similar magnitude, regardless of the data source. Again, there is less consistency across the models estimated with the alternative data sources for the remaining lags of subordinated debt spreads in the model. That is, different lags are statistically important and signs are different when alternative data sources are used to estimate the model. Overall, far fewer of the market leverage variables were statistically significant when the timeseries model was estimated using relatively younger bonds with larger issuance sizes. As with the full sample, parameter estimates for one-year and ten-year Treasury yields are more likely to be significant when Bloomberg data are used, than when IDC data are used. As with the market leverage variable estimates, far fewer of the stock market excess return variables were statistically significant when the model was estimated with the more restrictive bond characteristics than with the full sample.

Even after restricting the analysis to only those bonds that have been outstanding three years or less with issuance sizes greater than $\$ 150$ million, the $F$ test statistics for testing the equivalence of the variances for the error terms from the time-series model estimated with IDC and with Bloomberg data (tables $5 \mathrm{~A}$ and $5 \mathrm{~B}$, bottom panel) generally remain smaller than the lower bound for an equally distributed 0.05 critical value. As with the full sample, this finding suggests that there is more unexplained variance in the errors when the time series model is estimated with Bloomberg data rather than IDC data.

Tests for the exclusion of various subsets of variables in the time-series models estimated with alternative vendor data (IDC and Bloomberg) were performed for the full sample and for the restricted sample (consisting only of bonds outstanding three years or less with issuance sizes greater than $\$ 150$ million) by using the likelihood ratio principle. To implement each likelihood ratio test, we estimated the unconstrained time-series model described above by maximum likelihood and then estimated the constrained model (which excludes a subset of variables), also using the maximum likelihood procedure. Denoting the values of the sample maximum likelihood functions under the constrained and unconstrained models as $\ln L_{0}$ and $\ln L_{l}$, respectively, the likelihood ratio statistic was computed as $-2\left(\ln L_{0}-\ln L_{1}\right)$. This test statistic is 
Table 5A.

Parameter Estimates Using Alternative Data Souces ( $\mathrm{I}=$ Interactive Data Corporation, B = Bloomberg) Restricted Sample, Bonds Issued within the Last 3 Years with Issuance Size Greater than \$150 million

\begin{tabular}{|c|c|c|c|c|c|c|c|c|c|c|c|c|c|}
\hline \multirow[b]{2}{*}{$\begin{array}{l}\text { Explanatory } \\
\text { Variables }\end{array}$} & \multirow[b]{2}{*}{$\begin{array}{l}\text { Time } \\
\text { Period }\end{array}$} & \multirow[b]{2}{*}{$\begin{array}{l}\text { Data } \\
\text { Source }\end{array}$} & \multicolumn{11}{|c|}{ Banking Organization Name } \\
\hline & & & Amsouth & \begin{tabular}{|l} 
Bank \\
America
\end{tabular} & $\begin{array}{l}\text { Bank of } \\
\text { New York }\end{array}$ & \begin{tabular}{|l} 
Bank of \\
Boston
\end{tabular} & Citicorp & Comerica & Chase & Fleet & $\begin{array}{l}\text { First } \\
\text { Union }\end{array}$ & \begin{tabular}{|l} 
JP \\
Morgan \\
\end{tabular} & Keybank \\
\hline \multirow{6}{*}{$\begin{array}{l}\text { Subordinated Debt } \\
\text { Spreads }\end{array}$} & -1 & $\begin{array}{l}\text { I } \\
\text { B }\end{array}$ & $\begin{array}{l}-- \\
--\end{array}$ & $\begin{array}{l}0.90^{*} \\
0.59^{*}\end{array}$ & $\begin{array}{l}- \\
--\end{array}$ & $\begin{array}{r}-0.74 \\
4.17\end{array}$ & $\begin{array}{l}0.55^{*} \\
0.69^{*}\end{array}$ & $\begin{array}{l}0.68^{*} \\
0.57^{*}\end{array}$ & $\begin{array}{l}0.73^{*} \\
0.58^{*}\end{array}$ & $\begin{array}{l}0.88^{*} \\
0.47^{*}\end{array}$ & $\begin{array}{l}- \\
--\end{array}$ & $\begin{array}{l}0.79^{*} \\
0.78^{*}\end{array}$ & $\begin{array}{l}0.89^{*} \\
0.41^{*}\end{array}$ \\
\hline & -2 & $\begin{array}{l}\mathrm{I} \\
\mathrm{B}\end{array}$ & $\begin{array}{l}-- \\
--\end{array}$ & $\begin{array}{l}-0.17^{*} \\
0.13^{*}\end{array}$ & $\begin{array}{l}- \\
--\end{array}$ & $\begin{array}{l}-0.23 \\
-2.02\end{array}$ & $\begin{array}{r}-0.13 \\
0.06\end{array}$ & $0.52 * 0.10$ & $\begin{array}{l}0.06 \\
0.04\end{array}$ & ${ }^{-0.12}{ }^{*}$ & $\begin{array}{l}-- \\
--\end{array}$ & $\begin{array}{r}-0.26^{*} \\
-0.03\end{array}$ & $\begin{array}{r}0.24 \\
-0.05\end{array}$ \\
\hline & \multirow[t]{2}{*}{-3} & I & -- & 0.02 & - & -0.86 & $0.29 *$ & 0.20 & 0.10 & 0.09 & -- & 0.24 & -0.54 \\
\hline & & B & -- & 0.12 & -- & 5.35 & 0.04 & 0.03 & 0.09 & $0.19^{*}$ & -- & 0.08 & -0.28 \\
\hline & \multirow{2}{*}{-4} & I & -- & $0.17 *$ & -- & 0.11 & 0.17 & -0.08 & -0.01 & 0.11 & -- & 0.06 & 0.40 \\
\hline & & $\mathrm{B}$ & -- & 0.08 & -- & -0.89 & 0.05 & -0.22 & $0.21^{*}$ & $0.15^{*}$ & -- & \multicolumn{2}{|c|}{$0.120 .53^{*}$} \\
\hline \multirow{10}{*}{$\begin{array}{l}\text { Market Leverage } \\
\text { Ratios }\end{array}$} & \multirow{2}{*}{0} & I & -- & -0.01 & -- & 0.22 & $0.08^{*}$ & \multirow{4}{*}{$\begin{array}{ll}0.19^{*} & \\
& 0.0\end{array}$} & 0.02 & -0.01 & -- & $-0.06^{*}$ & 0.14 \\
\hline & & B & -- & -0.03 & -- & 0.38 & 0.01 & & $-0.07 *$ & $-0.04 *$ & -- & -0.03 & -0.13 \\
\hline & \multirow[b]{2}{*}{-1} & I & -- & 0.01 & -- & 0.42 & 0.01 & & 0.02 & $0.05^{*}$ & -- & 0.02 & -0.14 \\
\hline & & B & -- & 0.03 & -- & -1.40 & -0.03 & & $0.10^{*}$ & 0.02 & -- & -0.01 & $0.27^{*}$ \\
\hline & \multirow{2}{*}{-2} & I & -- & 0.02 & -- & -0.17 & $-0.08 *$ & $-0.21 *$ & -0.03 & $-0.09 *$ & -- & 0.05 & -0.07 \\
\hline & & B & -- & $-0.06^{*}$ & -- & 0.32 & 0.00 & $-0.16^{*}$ & 0.03 & 0.03 & -- & $0.05^{*}$ & 0.00 \\
\hline & -3 & I & -- & 0.03 & -- & 0.42 & -0.00 & -0.02 & 0.05 & $-0.25^{*}$ & -- & -0.03 & -0.05 \\
\hline & -3 & B & -- & $0.08^{*}$ & -- & -0.63 & -0.01 & 0.04 & -0.07 & -0.05 & -- & 0.02 & $-0.21^{*}$ \\
\hline & -4 & I & -- & $-0.03 *$ & -- & -0.71 & -0.02 & 0.08 & $-0.07 *$ & $0.28 *$ & -- & 0.02 & 0.08 \\
\hline & -4 & $\mathrm{~B}$ & -- & -0.02 & -- & -0.20 & 0.02 & 0.05 & 0.00 & $\begin{array}{r}-0.04 \\
\end{array}$ & -- & -0.02 & 0.11 \\
\hline & 0 & I & -- & $-0.15^{*}$ & -- & -1.41 & 0.18 & -0.04 & -0.10 & $-0.22 *$ & -- & $-0.23^{*}$ & -0.35 \\
\hline & 0 & B & -- & $-0.31^{*}$ & -- & 1.20 & -0.07 & $-0.18^{*}$ & $-0.33^{*}$ & $-0.28^{*}$ & -- & $-0.61^{*}$ & $-0.41^{*}$ \\
\hline & -1 & I & -- & -0.11 & -- & -0.57 & -0.14 & 0.05 & -0.09 & 0.09 & -- & -0.05 & 0.48 \\
\hline & -1 & B & -- & 0.02 & -- & -4.47 & -0.26 & 0.13 & 0.09 & 0.04 & -- & $0.70^{*}$ & 0.40 \\
\hline One Year Treasury & -2 & I & -- & 0.11 & -- & -0.21 & $-0.47^{*}$ & -0.00 & 0.16 & -0.16 & -- & 0.04 & -0.29 \\
\hline Rates & -2 & B & -- & $0.25^{*}$ & -- & 6.38 & 0.23 & 0.11 & $0.31 *$ & $0.32 *$ & -- & -0.03 & 0.07 \\
\hline & -3 & I & -- & 0.15 & -- & 1.23 & 0.02 & -0.04 & -0.08 & 0.23 & -- & 0.12 & 0.20 \\
\hline & -3 & B & -- & -0.12 & -- & -5.60 & -0.31 & $-0.21 *$ & $-0.40^{*}$ & $-0.28 *$ & -- & $-0.58^{*}$ & 0.09 \\
\hline & -4 & I & -- & -0.11 & -- & -1.88 & $0.27 *$ & -0.07 & 0.04 & -0.01 & -- & -0.00 & -0.06 \\
\hline & -4 & $\mathrm{~B}$ & -- & 0.06 & -- & 3.56 & 0.19 & 0.02 & $0.28 *$ & 0.13 & -- & $0.47 *$ & -0.19 \\
\hline & 0 & I & -- & 0.00 & -- & 1.13 & -0.19 & -0.03 & $-0.10^{*}$ & 0.04 & -- & 0.05 & 0.12 \\
\hline & 0 & B & -- & $0.13^{*}$ & -- & 0.73 & $-0.19^{*}$ & 0.11 & 0.10 & 0.12 & -- & $0.39^{*}$ & $0.40^{*}$ \\
\hline & -1 & I & -- & 0.04 & -- & -0.72 & 0.08 & -0.04 & 0.12 & -0.04 & -- & -0.01 & -0.10 \\
\hline & & B & -- & -0.07 & -- & 4.66 & $0.26^{*}$ & -0.14 & -0.1 & -0.02 & -- & $-0.59 *$ & $-0.53^{*}$ \\
\hline Ten Year Treasury & -2 & I & -- & -0.03 & -- & -1.16 & 0.23 & 0.00 & $0.16^{*}$ & $0.18^{*}$ & -- & -0.08 & 0.05 \\
\hline Rates & -2 & B & -- & $-0.15^{*}$ & -- & -6.84 & -0.17 & -0.06 & $-0.20^{*}$ & $-0.28 *$ & -- & 0.10 & -0.37 \\
\hline & -3 & I & -- & $-0.15^{*}$ & -- & -0.19 & -0.09 & 0.05 & 0.09 & -0.14 & -- & -0.17 & -0.21 \\
\hline & -3 & B & -- & $0.15^{*}$ & -- & 4.30 & 0.22 & 0.11 & $0.37^{*}$ & $0.36^{*}$ & -- & $0.40^{*}$ & 0.10 \\
\hline & -4 & I & -- & $0.19^{*}$ & -- & 1.96 & 0.01 & 0.07 & 0.08 & 0.02 & -- & $0.22 *$ & 0.08 \\
\hline & & B & -- & 0.00 & -- & -2.34 & -0.02 & 0.06 & $-0.15^{*}$ & -0.10 & -- & $-0.25^{*}$ & $0.42^{*}$ \\
\hline & 0 & I & -- & $-5.48^{*}$ & -- & 9.16 & -0.14 & $-2.74^{*}$ & -1.21 & $-8.51^{*}$ & -- & $-7.34^{*}$ & -0.77 \\
\hline & & B & -- & $-4.13 *$ & -- & -29.55 & -0.36 & -2.11 & $-4.77^{*}$ & -1.65 & -- & $-7.19^{*}$ & -6.83 \\
\hline & -1 & I & -- & $-2.37 *$ & -- & 51.32 & -1.03 & 0.99 & -1.16 & -0.33 & -- & $-4.55^{*}$ & 1.78 \\
\hline & -1 & B & -- & $-4.89 *$ & -- & -61.58 & $-2.02^{*}$ & $-3.37 *$ & $-4.02 *$ & -2.72 & -- & $-8.98^{*}$ & -0.83 \\
\hline Stock Market Excess & -2 & I & -- & -0.13 & -- & 26.04 & -0.51 & -1.94 & 0.58 & -0.85 & -- & 1.15 & -4.80 \\
\hline Returns & -2 & B & -- & $-4.90^{*}$ & -- & -36.39 & $-6.82 *$ & $-4.78^{*}$ & -0.02 & $-3.41^{*}$ & -- & 0.24 & 2.06 \\
\hline & -3 & I & -- & -0.023 & -- & 27.44 & -1.27 & -3.03 & 0.75 & $-5.44 *$ & -- & $-4.29 *$ & -1.91 \\
\hline & -3 & B & - & -2.09 & -- & -39.61 & -3.52 & -1.98 & $-2.77 *$ & -1.88 & -- & -1.22 & $-10.41^{*}$ \\
\hline & -4 & I & -- & $-2.08^{*}$ & -- & -1.73 & -1.66 & -1.48 & \begin{tabular}{l|l|} 
& -1.64 \\
\end{tabular} & -0.74 & -- & -2.27 & $-7.45^{*}$ \\
\hline & -4 & B & -- & -1.36 & -- & -65.97 & -0.28 & -0.43 & $-3.81 *$ & -1.58 & -- & -0.62 & $-10.20 *$ \\
\hline $\mathrm{R}^{2}$ & & I & -- & 0.9266 & -- & 0.9364 & 0.9233 & 0.92 & 0.9256 & 0.909 & -- & 0.9324 & 0.9492 \\
\hline $\mathrm{K}$ & & $\mathrm{B}$ & -- & 0.9116 & -- & 0.985 & 0.9286 & 0.9476 & 0.9111 & 0.877 & -- & 0.9344 & 0.8788 \\
\hline $\begin{array}{l}F \text { Test Statistic for } \\
\text { Equal Variances of } \\
\text { Error Terms }{ }^{2}\end{array}$ & & & & & & & & & & & & & \\
\hline & & & -- & 0.791 & -- & 5.746 & 1.192 & 1.772 & 0.784 & 0.833 & -- & 0.963 & 1.402 \\
\hline Lower Bound, K1 & & & -- & 1.196 & -- & 2.194 & 1.428 & 1.411 & 1.226 & 1.285 & -- & 1.338 & 1.846 \\
\hline Upper Bound, K2 & & & -- & 1.196 & -- & 2.194 & 1.428 & 1.411 & 1.226 & 1.285 & -- & 1.338 & 1.846 \\
\hline
\end{tabular}

'Significance of each parameter estimate, with a five percent level of confidence, is indicated with an asterisk $\left({ }^{*}\right)$ next to the parameter and also by the entry being left-justified within each column.

${ }^{2}$ Test Statistic has an F-distribution with $n_{1}-1$ and $n_{B}-1$ degrees of freedom. A test of equal variances for error terms of $\left(\mathrm{H}_{0}: \sigma_{B}^{2}=\sigma_{I}^{2}\right)$ versus unequal variances $\left(H_{1}: \sigma_{B}^{2} \neq \sigma_{I}^{2}\right)$ is two-tailed; that is $H_{0}$ is rejected for small (below lower bounds, $\mathrm{K}_{1}$ ) or large (above upper bounds, $\mathrm{K}_{2}$ ) F test statistics. 
Table 5B.

Parameter Estimates Using Alternative Data Souces ( $\mathrm{I}=$ Interactive Data Corporation, $\mathrm{B}=\mathrm{Bloomberg})^{\mathbf{1}}$ Restricted Sample, Bonds Issued within the Last 3 Years with Issuance Size Greater than $\$ \mathbf{1 5 0}$ million

\begin{tabular}{|c|c|c|c|c|c|c|c|c|c|c|c|c|c|c|}
\hline \multirow[b]{2}{*}{$\begin{array}{l}\text { Explanatory } \\
\text { Variables }\end{array}$} & \multirow[b]{2}{*}{$\begin{array}{c}\text { Time } \\
\text { Period }\end{array}$} & \multirow[b]{2}{*}{$\begin{array}{c}\text { Data } \\
\text { Source }\end{array}$} & \multicolumn{12}{|c|}{ Banking Organization } \\
\hline & & & Mellon & $\begin{array}{l}\text { First Amer } \\
\text { Bk Corp }\end{array}$ & Banc One & PNC & \begin{tabular}{|l|} 
Regions \\
Financial \\
Corporation \\
\end{tabular} & \begin{tabular}{|l|} 
Republic \\
New York
\end{tabular} & Southtrust & Suntrust & \begin{tabular}{|l} 
Union \\
Planters
\end{tabular} & \begin{tabular}{|l} 
US Bank \\
NA
\end{tabular} & Wachovia & \begin{tabular}{|l} 
Wells \\
Fargo
\end{tabular} \\
\hline \multirow{8}{*}{$\begin{array}{l}\text { Subordinated Debt } \\
\text { Spreads }\end{array}$} & -1 & I & $0.77^{*}$ & -- & $0.65^{*}$ & $0.88^{*}$ & -- & -- & -- & -- & -- & 0.46 & $0.52^{*}$ & 0.25 \\
\hline & & B & $0.56^{*}$ & -- & $0.52^{*}$ & $0.58^{*}$ & -- & -- & -- & -- & -- & 0.36 & $0.32 *$ & 0.43 \\
\hline & -2 & I & -0.24 & -- & $0.21^{*}$ & -0.04 & -- & -- & - & -- & -- & -0.10 & -0.05 & -0.04 \\
\hline & & B & 0.32 & -- & $0.22 *$ & 0.14 & -- & -- & -- & -- & -- & -0.25 & 0.04 & -0.18 \\
\hline & -3 & I & 0.19 & -- & 0.01 & 0.19 & - & -- & -- & -- & -- & 0.31 & 0.06 & -0.04 \\
\hline & & B & 0.02 & -- & $0.18^{*}$ & 0.11 & -- & -- & -- & -- & -- & 0.49 & $0.22 *$ & 0.17 \\
\hline & -4 & I & -0.01 & -- & 0.11 & -0.16 & - & -- & -- & -- & -- & 0.40 & $0.22 *$ & 0.30 \\
\hline & & B & -0.09 & -- & 0.04 & 0.06 & -- & -- & -- & -- & -- & -0.18 & 0.15 & 0.08 \\
\hline \multirow{10}{*}{$\begin{array}{l}\text { Market Leverage } \\
\text { Ratios }\end{array}$} & 0 & I & 0.26 & -- & $0.08^{*}$ & 0.13 & -- & -- & -- & -- & -- & 0.22 & $-0.44^{*}$ & 0.03 \\
\hline & & B & 0.30 & -- & $0.04^{*}$ & 0.00 & -- & -- & -- & -- & -- & 0.12 & 0.07 & 0.04 \\
\hline & -1 & I & -0.19 & -- & -0.01 & -0.08 & -- & -- & -- & -- & -- & 0.08 & 0.13 & 0.01 \\
\hline & & B & -0.05 & -- & 0.02 & 0.15 & -- & -- & -- & -- & -- & 0.21 & 0.18 & -0.04 \\
\hline & -2 & I & -0.14 & -- & $-0.13^{*}$ & -0.10 & -- & -- & -- & -- & -- & -0.20 & -0.23 & -0.05 \\
\hline & & B & -0.51 & -- & -0.04 & -0.15 & - & -- & -- & -- & -- & -0.55 & -0.38 & -0.00 \\
\hline & -3 & I & -0.21 & -- & 0.00 & -0.05 & -- & -- & -- & -- & -- & 0.25 & 0.04 & -0.05 \\
\hline & & B & 0.10 & -- & -0.00 & $-0.21^{*}$ & - & -- & -- & -- & -- & -0.30 & 0.06 & -0.13 \\
\hline & -4 & I & $0.55^{*}$ & -- & 0.03 & 0.08 & - & - & - & -- & -- & -0.50 & 0.06 & 0.05 \\
\hline & & B & 0.28 & -- & $-0.05^{*}$ & $0.18^{*}$ & -- & -- & -- & -- & -- & 0.16 & 0.09 & 0.16 \\
\hline \multirow{10}{*}{$\begin{array}{l}\text { One Year Treasury } \\
\text { Rates }\end{array}$} & 0 & I & -0.22 & -- & 0.03 & $\begin{array}{l}-0.02 \\
\end{array}$ & -- & -- & -- & -- & -- & -0.32 & $0.27^{*}$ & -0.67 \\
\hline & & B & $-0.56^{*}$ & -- & -0.06 & -0.15 & -- & -- & -- & -- & -- & -0.20 & 0.20 & -0.21 \\
\hline & -1 & I & 0.42 & -- & -0.15 & 0.09 & -- & -- & -- & -- & -- & 0.21 & -0.13 & 0.11 \\
\hline & & B & $0.75^{*}$ & -- & 0.06 & 0.03 & -- & -- & -- & -- & -- & $0.93 *$ & -0.25 & -0.22 \\
\hline & -2 & I & -0.42 & -- & -0.16 & -0.05 & -- & -- & -- & -- & -- & -0.10 & -0.19 & 0.12 \\
\hline & & B & -0.33 & -- & 0.02 & -0.08 & -- & -- & -- & -- & -- & -0.89 & $0.30^{*}$ & 0.28 \\
\hline & -3 & I & 0.18 & -- & -0.00 & -0.19 & -- & - & -- & -- & -- & -0.30 & 0.20 & -0.07 \\
\hline & & B & -0.40 & -- & $-0.34 *$ & $-0.41^{*}$ & -- & -- & -- & -- & -- & 0.43 & $-0.58^{*}$ & -0.27 \\
\hline & -4 & I & -0.16 & -- & $0.22 *$ & 0.01 & -- & -- & -- & -- & -- & -0.19 & -0.11 & -0.05 \\
\hline & & B & 0.40 & -- & $0.22 *$ & $0.46^{*}$ & -- & -- & -- & -- & -- & -0.40 & 0.06 & -0.08 \\
\hline \multirow{10}{*}{$\begin{array}{l}\text { Ten Year Treasury } \\
\text { Rates }\end{array}$} & 0 & I & \begin{tabular}{|c|}
-0.13 \\
\end{tabular} & -- & \begin{tabular}{l|}
-0.03 \\
\end{tabular} & -0.10 & -- & -- & -- & -- & -- & 0.16 & $-0.28^{*}$ & 0.19 \\
\hline & & B & 0.17 & -- & 0.04 & 0.03 & - & -- & -- & -- & -- & 0.25 & $-0.33^{*}$ & -0.08 \\
\hline & -1 & I & -0.10 & -- & 0.13 & -0.06 & -- & -- & -- & -- & -- & -0.15 & 0.15 & -0.18 \\
\hline & & B & -0.49 & -- & -0.05 & -0.08 & -- & -- & -- & -- & -- & $-0.48^{*}$ & $0.27^{*}$ & 0.29 \\
\hline & -2 & I & 0.33 & -- & 0.04 & 0.07 & -- & -- & -- & -- & -- & 0.19 & 0.10 & 0.18 \\
\hline & & B & 0.47 & -- & -0.04 & 0.11 & -- & -- & -- & -- & -- & 0.39 & -0.20 & -0.15 \\
\hline & -3 & I & -0.21 & -- & -0.03 & 0.11 & -- & - & -- & -- & -- & 0.25 & -0.07 & 0.04 \\
\hline & & B & 0.26 & -- & $0.29 *$ & $0.32 *$ & -- & -- & -- & -- & -- & -0.41 & $0.44^{*}$ & 0.17 \\
\hline & -4 & I & 0.26 & -- & -0.06 & 0.07 & -- & -- & -- & -- & -- & -0.11 & $0.21^{*}$ & 0.12 \\
\hline & & $\mathrm{B}$ & -0.33 & -- & $-0.17^{*}$ & $-0.28^{*}$ & -- & -- & -- & -- & -- & 0.43 & -0.00 & 0.13 \\
\hline \multirow{10}{*}{$\begin{array}{l}\text { Stock Market Excess } \\
\text { Returns }\end{array}$} & 0 & I & -1.49 & -- & -1.00 & -0.70 & -- & -- & -- & -- & -- & -2.85 & -10.70 & -4.92 \\
\hline & & B & -1.23 & -- & -1.45 & -2.35 & -- & -- & -- & -- & -- & 7.36 & -0.86 & -0.71 \\
\hline & -1 & I & -4.67 & -- & -1.57 & -4.52 & -- & -- & -- & -- & -- & -4.39 & -4.19 & -2.95 \\
\hline & & B & -4.77 & -- & $-2.91^{*}$ & -1.82 & -- & -- & -- & -- & -- & 6.12 & -0.01 & -4.75 \\
\hline & -2 & I & -6.92 & -- & -0.53 & -3.61 & -- & -- & - & -- & -- & -16.43 & $-7.71 *$ & -2.54 \\
\hline & & B & -8.06 & -- & -1.71 & -1.17 & -- & -- & -- & -- & -- & -0.21 & $-9.13^{*}$ & -4.21 \\
\hline & -3 & I & -3.08 & -- & 0.05 & -2.36 & -- & -- & -- & - & -- & -7.97 & -2.31 & -1.51 \\
\hline & & B & -4.79 & -- & -1.60 & $-7.36^{*}$ & - & -- & -- & -- & - & -18.24 & -3.22 & $-10.53^{*}$ \\
\hline & -4 & I & 0.12 & -- & $-2.34 *$ & -0.97 & - & -- & -- & -- & -- & $-14.45^{*}$ & -2.02 & -3.16 \\
\hline & & B & 2.47 & -- & -1.28 & -2.24 & -- & -- & -- & -- & -- & -6.85 & -2.40 & -0.15 \\
\hline \multirow{2}{*}{$\mathrm{R}^{2}$} & & I & 0.8478 & -- & 0.9415 & 0.9294 & -- & -- & -- & -- & -- & 0.8288 & 0.7486 & 0.6996 \\
\hline & & $\mathrm{B}$ & 0.7812 & -- & 0.9345 & 0.9389 & -- & -- & -- & -- & -- & 0.5058 & 0.7407 & 0.8331 \\
\hline \multirow[t]{4}{*}{$\begin{array}{l}\text { F Test Statistic for } \\
\text { Equal Variances of } \\
\text { Error Terms }{ }^{2}\end{array}$} & & & & & & & & & & & & & & \\
\hline & & & 0.677 & -- & 0.953 & 1.313 & -- & -- & -- & -- & -- & 0.406 & 0.846 & 2.552 \\
\hline & & & 1.667 & -- & 1.284 & 1.48 & -- & -- & -- & -- & -- & 2.13 & 1.472 & 1.907 \\
\hline & & & 1.667 & -- & 1.284 & 1.48 & - & -- & - & - & -- & 2.13 & 1.472 & 1.907 \\
\hline
\end{tabular}

${ }^{1}$ Significance of each parameter estimate, with a five percent level of confidence, is indicated with an asterisk $\left(^{*}\right)$ next to the parameter and also by the entry being left-justified within each column.

${ }^{2}$ Test Statistic has an F-distribution with $\mathrm{n}_{1}-1$ and $\mathrm{n}_{\mathrm{B}}-1$ degrees of freedom. A test of equal variances for error terms of $\left(\mathrm{H}_{0}: \sigma_{B}^{2}=\sigma_{1}^{2}\right)$ versus unequal variances $\left(\mathrm{H}_{1}: \sigma_{B}^{2} \neq \sigma_{\mathrm{I}}^{2}\right)$ is two-tailed; that is $\mathrm{H}_{\mathrm{b}}$ is rejected for small $($ below lower bounds, $\mathrm{K}_{1}$ ) or large (above upper bounds, $\mathrm{K}_{2}$ ) $\mathrm{F}$ test statistics. 
distributed asymptotically as a Chi-square random variable with degrees of freedom equal to the difference between the number of parameters estimated in the unconstrained and constrained models. $^{54}$

Table 6 (Table 7) presents likelihood ratio test statistics, for the full sample (restricted sample) using each alternative vendor data source, that exclude 1) lagged spreads; 2) market leverage variables; 3) one-year Treasury rate variables; 4) ten-year Treasury rate variables; and, 5) excess stock market return variables. The reported Chi-square critical values for each test are for a 0.05 significance level. A likelihood ratio test statistic greater than its critical value (indicated in bold type face in tables 6 and 7) suggests that it would be inconsistent with the data to exclude the specific subset of variables under consideration. That is, the constrained model is rejected by the data.

Overall, the likelihood ratio test statistics presented in table 6 confirm the importance of including each of the subsets of variables (i.e., lagged spreads, market leverage variables, oneyear Treasury rate variables, ten-year Treasury rate variables, and excess stock market return variables) into the time-series model for the full sample of bonds. First, excluding lagged spreads from the time-series model is not accepted for data from either IDC or Bloomberg, since only one likelihood ratio test statistic in the "no lagged spreads panel" is smaller than the critical value of 9.49 .

Second, more frequently than not, the hypothesis that market leverage variables should be excluded from the time-series model is rejected. For only 22 (35) percent of the banking organizations in the full sample, IDC (Bloomberg) data was consistent with excluding market leverage variables. These findings are consonant with the observation that the market leverage variables appeared to be significant more often in table 4 when IDC data were used than when Bloomberg data were used.

Third, the hypothesis that term-structure variables should be excluded from the timeseries model for the full sample is rejected for most of the 23 banking organizations analyzed, regardless of whether IDC or Bloomberg data is used. Bloomberg spread data were consistent with excluding either one- or ten-year Treasury rates from the time-series model for less than 20

\footnotetext{
${ }^{54}$ The likelihood ratio test is distributed as Chi-squared only asymptotically. For finite sample sizes, the limiting distribution is unknown, and tests may be biased toward rejection.
} 
Table 6.

Likelihood Ratio (LR) Test Statistics, Exclusion of Subsets of Variables ${ }^{1}$

Full Sample, No Restrictions on Age of Bonds or Issuance Size

\begin{tabular}{|c|c|c|c|c|c|c|c|c|c|c|c|c|c|c|c|}
\hline \multirow{3}{*}{ Banking Organization Name } & \multicolumn{3}{|c|}{ No Lagged Spreads } & \multicolumn{3}{|c|}{$\begin{array}{l}\text { No Contemporaneous or Lagged } \\
\text { Market Leverage Variables }\end{array}$} & \multicolumn{3}{|c|}{$\begin{array}{c}\text { No Contemporaneous or Lagged } \\
1 \text { Yr. Treasury Securities }\end{array}$} & \multicolumn{3}{|c|}{$\begin{array}{l}\text { No Contemporaneous or Lagged } \\
\text { 10Yr. Treasury Securities }\end{array}$} & \multicolumn{3}{|c|}{$\begin{array}{l}\text { No Contemporaneous or Lagged } \\
\text { Excess Return Variables }\end{array}$} \\
\hline & \multicolumn{2}{|c|}{ Test Statistic (LR) } & \multirow{2}{*}{\begin{tabular}{|c|} 
Critical \\
Value \\
$(0.05)$ DF 4 \\
\end{tabular}} & \multicolumn{2}{|c|}{ Test Statistic (LR) } & \multirow{2}{*}{\begin{tabular}{|c|} 
Critical \\
Value \\
$(0.05)$ DF 5
\end{tabular}} & \multicolumn{2}{|c|}{ Test Statistic (LR) } & \multirow{2}{*}{\begin{tabular}{|c} 
Critical \\
Value \\
$(0.05)$ DF 5
\end{tabular}} & \multicolumn{2}{|c|}{ Test Statistic (LR) } & \multirow{2}{*}{\begin{tabular}{|c} 
Critical \\
Value \\
$(0.05)$ DF 5
\end{tabular}} & \multicolumn{2}{|c|}{ Test Statistic (LR) } & \multirow{2}{*}{$\begin{array}{l}\text { Critical } \\
\text { Value } \\
(0.05) \text { DF } 5\end{array}$} \\
\hline & $\begin{array}{l}\text { IDC } \\
\text { data }\end{array}$ & $\begin{array}{c}\text { Bloomberg } \\
\text { data }\end{array}$ & & $\begin{array}{l}\text { IDC } \\
\text { data }\end{array}$ & $\begin{array}{c}\text { Bloomberg } \\
\text { data }\end{array}$ & & $\begin{array}{l}\text { IDC } \\
\text { data }\end{array}$ & $\begin{array}{c}\text { Bloomberg } \\
\text { data }\end{array}$ & & $\begin{array}{l}\text { IDC } \\
\text { data }\end{array}$ & $\begin{array}{c}\text { Bloomberg } \\
\text { data }\end{array}$ & & $\begin{array}{l}\text { IDC } \\
\text { data }\end{array}$ & $\begin{array}{c}\text { Bloomberg } \\
\text { data }\end{array}$ & \\
\hline Amsouth & 412.38 & 381.81 & 9.49 & 3.83 & 9.21 & 11.1 & \begin{tabular}{|l|}
19.14 \\
\end{tabular} & 17.75 & 11.1 & 41.55 & 26.56 & 11.1 & 3.25 & 10.39 & 11.1 \\
\hline Bank America & 7586.30 & 7011.89 & 9.49 & 116.40 & 29.50 & 11.1 & 76.46 & 123.20 & 11.1 & 17.60 & 86.52 & 11.1 & 132.50 & 92.00 & 11.1 \\
\hline Bank of New York & 1431.92 & 1715.63 & 9.49 & 49.58 & 40.70 & 11.1 & 59.26 & 40.58 & 11.1 & 20.78 & 21.24 & 11.1 & 17.60 & 10.86 & 11.1 \\
\hline Bank of Boston & 6.57 & 87.70 & 9.49 & 39.96 & 52.58 & 11.1 & 22.86 & $\mathbf{5 4 . 4 6}$ & 11.1 & 30.69 & 79.13 & 11.1 & 37.67 & 30.52 & 11.1 \\
\hline Citicorp & 3143.17 & 2757.94 & 9.49 & 318.42 & 140.68 & 11.1 & 80.62 & 33.62 & 11.1 & 35.14 & 15.72 & 11.1 & 21.26 & 28.56 & 11.1 \\
\hline Comerica & 1442.62 & 1544.66 & 9.49 & 16.71 & 34.41 & 11.1 & 22.98 & 64.47 & 11.1 & 8.44 & 16.26 & 11.1 & 18.55 & 43.13 & 11.1 \\
\hline Chase & 3150.92 & 3439.55 & 9.49 & -29.08 & 10.56 & 11.1 & 5.68 & 241.42 & 11.1 & -44.12 & 56.92 & 11.1 & -30.64 & 84.80 & 11.1 \\
\hline Fleet & 565.33 & 526.05 & 9.49 & 21.88 & 14.49 & 11.1 & 17.65 & 26.85 & 11.1 & 11.81 & 26.01 & 11.1 & 34.25 & 10.56 & 11.1 \\
\hline First Union & 3334.47 & 2720.44 & 9.49 & 32.08 & 13.98 & 11.1 & 18.96 & 151.34 & 11.1 & 18.90 & 90.26 & 11.1 & 19.10 & 47.18 & 11.1 \\
\hline JPMorgan & 1708.40 & 1521.18 & 9.49 & 41.22 & 12.25 & 11.1 & 21.64 & 22.89 & 11.1 & 17.05 & 22.60 & 11.1 & 79.14 & 43.85 & 11.1 \\
\hline Keybank & 439.53 & 414.38 & 9.49 & 9.94 & 32.96 & 11.1 & 13.65 & 6.89 & 11.1 & 3.76 & 8.15 & 11.1 & 8.09 & 39.47 & 11.1 \\
\hline Mellon & 756.77 & 628.70 & 9.49 & 32.81 & 9.95 & 11.1 & 15.03 & 40.44 & 11.1 & 6.34 & 27.48 & 11.1 & 13.67 & 8.97 & 11.1 \\
\hline First Amer Bk Corp & 245.98 & 242.12 & 9.49 & 15.96 & 16.27 & 11.1 & 21.77 & 16.01 & 11.1 & 15.75 & 9.20 & 11.1 & 6.49 & 2.26 & 11.1 \\
\hline Banc One & 1656.43 & 1603.77 & 9.49 & 210.57 & 89.12 & 11.1 & 34.54 & 24.70 & 11.1 & 21.59 & 22.37 & 11.1 & 42.44 & 25.79 & 11.1 \\
\hline$P N C$ & 371.58 & 399.78 & 9.49 & 15.22 & 19.48 & 11.1 & 10.00 & 27.98 & 11.1 & 15.68 & 17.83 & 11.1 & 11.42 & 15.31 & 11.1 \\
\hline Regions Financial Corp & 65.23 & 211.82 & 9.49 & 3.05 & 7.90 & 11.1 & 3.28 & 9.31 & 11.1 & 3.65 & 6.94 & 11.1 & 4.32 & 10.08 & 11.1 \\
\hline Republic New York & 2102.48 & 1780.49 & 9.49 & 30.86 & 57.19 & 11.1 & 106.84 & 34.88 & 11.1 & $\mathbf{7 6 . 4 8}$ & 32.39 & 11.1 & $\mathbf{5 3 . 5 0}$ & 27.02 & 11.1 \\
\hline Southtrust & 162.37 & 476.75 & 9.49 & 12.34 & 25.05 & 11.1 & 1.45 & 15.14 & 11.1 & 8.53 & 14.22 & 11.1 & 10.41 & 19.51 & 11.1 \\
\hline Suntrust & 878.14 & 1019.25 & 9.49 & 62.02 & 10.34 & 11.1 & 10.35 & 6.73 & 11.1 & 33.11 & 24.09 & 11.1 & 16.12 & 15.07 & 11.1 \\
\hline Union Planters & 199.21 & 130.81 & 9.49 & 3.26 & 5.37 & 11.1 & 14.90 & 13.32 & 11.1 & 20.54 & 13.94 & 11.1 & 2.35 & 14.44 & 11.1 \\
\hline US Bank NA & 197.13 & 175.43 & 9.49 & 16.70 & 23.75 & 11.1 & 51.43 & 23.63 & 11.1 & 34.79 & 24.46 & 11.1 & 25.48 & 35.45 & 11.1 \\
\hline Wachovia & 983.19 & 1017.22 & 9.49 & 19.44 & 8.75 & 11.1 & 15.58 & 14.45 & 11.1 & 27.69 & 26.33 & 11.1 & 33.05 & 25.73 & 11.1 \\
\hline Wells Fargo & 939.33 & 866.30 & 9.49 & 24.46 & 2.52 & 11.1 & 9.45 & 34.69 & 11.1 & 4.38 & 10.87 & 11.1 & 28.53 & 35.32 & 11.1 \\
\hline \begin{tabular}{|l|} 
Proportion of banking \\
organizations with statistically \\
significant LR differences
\end{tabular} & 0.96 & 1.00 & & 0.78 & 0.65 & & 0.74 & 0.87 & & 0.70 & 0.83 & & 0.70 & 0.74 & \\
\hline
\end{tabular}

${ }^{1}$ Test statistics are asymptotically distributed as Chi-squared divided by degrees of freedom (DF) where DF is the number of restrictions tested. The critical values are for Chi-squared/DF. Tests where the null hypothesis excluding the variables is not accepted are indicated in bold face type as are banking organizations calssified as LCBO's as of December 31, 1998 by banking supervisors. 
Table 7.

Likelihood Ratio (LR) Test Statistics, Exclusion of Subsets of Variables ${ }^{1}$ Restricted Sample, Bonds Issued within the Last 3 Years with Issuance Size Greater than \$150 million

\begin{tabular}{|c|c|c|c|c|c|c|c|c|c|c|c|c|c|c|c|}
\hline \multirow[b]{2}{*}{ Banking Organization Name } & \multicolumn{3}{|c|}{ No Lagged Spreads } & \multicolumn{3}{|c|}{$\begin{array}{l}\text { No Contemporaneous or Lagged } \\
\text { Market Leverage Variables }\end{array}$} & \multicolumn{3}{|c|}{$\begin{array}{l}\text { No Contemporaneous or Lagged } \\
\text { 1Yr. Treasury Securities }\end{array}$} & \multicolumn{3}{|c|}{$\begin{array}{c}\text { No Contemporaneous or Lagged } \\
\text { 10Yr. Treasury Securities }\end{array}$} & \multicolumn{3}{|c|}{$\begin{array}{l}\text { No Contemporaneous or Lagged } \\
\text { Excess Return Variables }\end{array}$} \\
\hline & $\begin{array}{l}\text { Test Stat } \\
\text { IDC } \\
\text { data }\end{array}$ & $\begin{array}{l}\text { Blistic (LR) } \\
\text { daomberg } \\
\text { data }\end{array}$ & $\begin{array}{c}\text { Critical } \\
\text { Value } \\
(0.05) \mathrm{DF} 4\end{array}$ & $\begin{array}{l}\text { Test Stat } \\
\text { IDC data }\end{array}$ & $\begin{array}{l}\text { istic (LR) } \\
\text { Bloomberg } \\
\text { data }\end{array}$ & \begin{tabular}{|c|} 
Critical \\
Value $(0.05)$ \\
DF 5
\end{tabular} & $\begin{array}{r}\text { Test Sta } \\
\text { IDC data }\end{array}$ & $\begin{array}{l}\text { istic (LR) } \\
\text { Bloomberg } \\
\text { data }\end{array}$ & \begin{tabular}{|c} 
Critical \\
Value \\
$(0.05) \mathrm{DF} 5$
\end{tabular} & $\begin{array}{r}\text { Test Sta } \\
\text { IDC data }\end{array}$ & $\begin{array}{l}\text { istic (LR) } \\
\text { Bloomberg } \\
\text { data }\end{array}$ & \begin{tabular}{|c|} 
Critical \\
Value $(0.05)$ \\
DF 5
\end{tabular} & $\begin{array}{l}\text { Test Stat } \\
\text { IDC } \\
\text { data }\end{array}$ & $\begin{array}{l}\text { Blistic }(L R) \\
\text { Bloomberg } \\
\text { data }\end{array}$ & \begin{tabular}{|c} 
Critical \\
Value \\
$(0.05)$ DF 5
\end{tabular} \\
\hline Amsouth & & & 9.49 & & & 11.1 & & & 11.1 & & & 11.1 & & & 11.1 \\
\hline Bank America & 785.87 & 653.15 & 9.49 & 14.02 & 28.69 & 11.1 & 25.33 & 41.45 & 11.1 & 18.80 & 19.92 & 11.1 & 51.05 & 48.58 & 11.1 \\
\hline Bank of New York & & & 9.49 & & & 11.1 & & & 11.1 & & & 11.1 & & & 11.1 \\
\hline Bank of Boston & 6.57 & 87.70 & 9.49 & 39.96 & 52.58 & 11.1 & 22.86 & 54.46 & 11.1 & 30.69 & 79.13 & 11.1 & 37.67 & 30.52 & 11.1 \\
\hline Citicorp & 170.06 & 171.77 & 9.49 & 56.69 & 4.71 & 11.1 & 25.80 & 30.63 & 11.1 & 9.08 & 23.03 & 11.1 & 2.33 & 22.08 & 11.1 \\
\hline Comerica & 204.39 & 239.15 & 9.49 & 8.47 & 8.26 & 11.1 & 3.75 & 15.41 & 11.1 & 3.16 & 12.27 & 11.1 & 5.95 & 15.88 & 11.1 \\
\hline Chase & 520.15 & 455.73 & 9.49 & 17.49 & 15.92 & 11.1 & 14.92 & 46.50 & 11.1 & 17.78 & 29.16 & 11.1 & 6.63 & 33.01 & 11.1 \\
\hline Fleet & 463.56 & 416.18 & 9.49 & 27.19 & 11.55 & 11.1 & 20.48 & 23.77 & 11.1 & 12.80 & 25.25 & 11.1 & 37.54 & 9.20 & 11.1 \\
\hline First Union & & & 9.49 & & & 11.1 & & & 11.1 & & & $11 . \overline{1}$ & & & $11 . \overline{1}$ \\
\hline JP Morgan & 178.61 & 243.75 & 9.49 & 22.81 & 19.06 & 11.1 & 14.81 & 51.85 & 11.1 & 10.64 & 39.38 & 11.1 & 33.71 & 40.94 & 11.1 \\
\hline Keybank & 132.46 & 33.92 & 9.49 & 9.71 & 23.77 & 11.1 & 12.21 & 21.35 & 11.1 & 4.52 & 34.90 & 11.1 & 10.68 & 29.96 & 11.1 \\
\hline Mellon & 51.32 & 32.46 & 9.49 & 14.63 & 7.14 & 11.1 & 12.03 & 14.60 & 11.1 & 12.82 & 12.80 & 11.1 & 4.60 & 4.99 & 11.1 \\
\hline First Amer Bk Corp & 1544.07 & $15 \overline{3} . \overline{96}$ & 9.49 & 1562.97 & 1587.47 & 11.1 & $1554 . \overline{08}$ & $15 \overline{77} .30$ & 11.1 & 1552.03 & $1 \overline{1543.08}$ & $11 . \overline{1}$ & 1545.55 & 1599.68 & 11.1 \\
\hline Banc One & 547.14 & 507.78 & 9.49 & 95.04 & 42.48 & 11.1 & 23.50 & 22.47 & 11.1 & 12.10 & 22.79 & 11.1 & 9.77 & 15.28 & 11.1 \\
\hline$P N C$ & 159.90 & 182.65 & 9.49 & 7.61 & 22.94 & 11.1 & 9.17 & 44.31 & 11.1 & 9.80 & 33.23 & 11.1 & 7.29 & 17.25 & 11.1 \\
\hline Regions Financial Corp & & & 9.49 & & & 11.1 & & & 11.1 & & & 11.1 & & & 11.1 \\
\hline Republic New York & & & $\overline{9} . \overline{4} \overline{9}$ & & & 11.1 & & & 11.1 & & & 11.1 & & & $11 . \overline{1}$ \\
\hline Southtrust & & & 9.49 & & & 11.1 & & & 11.1 & & & 11.1 & & & 11.1 \\
\hline Suntrust & & & 9.49 & & & 11.1 & & & 11.1 & & & 11.1 & & & 11.1 \\
\hline Union Planters & & & 9.49 & & & 11.1 & & & 11.1 & & & 11.1 & & & 11.1 \\
\hline US Bank NA & 19.89 & 22.31 & 9.49 & 42.97 & 32.00 & 11.1 & 65.90 & 35.39 & 11.1 & 61.77 & 32.88 & 11.1 & 51.81 & 39.16 & 11.1 \\
\hline Wachovia & 74.64 & 51.95 & 9.49 & 35.92 & 12.52 & 11.1 & 13.03 & 42.19 & 11.1 & 23.64 & 47.87 & 11.1 & 46.56 & 27.51 & 11.1 \\
\hline Wells Fargo & 3.84 & 10.72 & 9.49 & 4.51 & 10.49 & 11.1 & 9.72 & 17.69 & 11.1 & 5.44 & 19.48 & 11.1 & 3.79 & 25.81 & 11.1 \\
\hline $\begin{array}{l}\text { Proportion of banking organizations } \\
\text { with statistically significant LR } \\
\text { differences }\end{array}$ & 0.93 & 1.00 & & 0.87 & 0.73 & & 0.80 & 0.93 & & 0.67 & 0.80 & & 0.80 & 0.87 & \\
\hline
\end{tabular}

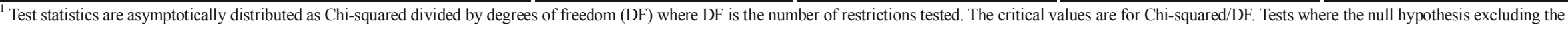
variables is not accepted are indicated in bold face type as are banking organizations calssified as LCBO's as of December 31, 1998 by banking supervisors. 
percent of such banking organizations. And, IDC spread data were consistent with excluding one-year (ten-year) Treasury rates from the time-series model for about 25 (30) percent of such banking organizations.

Fourth, the likelihood ratio test statistics presented in table 6 suggest that both IDC and Bloomberg subordinated debt spread data for banking organizations contain statistically significant excess stock market return effects. Bloomberg (IDC) data are only consistent with excluding stock market excess returns from the time-series model estimated with the full sample for 26 (30) percent of the 23 banking organizations analyzed.

For bonds issued within the last 3 years with issuance size greater than $\$ 150$ million, the likelihood ratio test statistics again confirm the importance of including each of the subsets of variables (i.e., lagged spreads, market leverage variables, one-year Treasury rate variables, tenyear Treasury rate variables, and excess stock market return variables) into the time-series model. Most of the likelihood ratio test statistics presented in each column of table 7 are greater than their respective critical values. Moreover, the proportion of banking organizations in each column of table 7 with a test statistic greater than its respective critical value is about the same as the comparable proportion of banking organizations contained in table 6 .

Given that the likelihood ratio test statistics validate that each subset of variables should not be excluded from the time-series model for the majority of banking organizations under consideration, we next considered whether the parameter estimates are statistically different when IDC data, rather than Bloomberg data, are used to estimate the time-series model. Likelihood ratio test statistics for the equality of all parameter estimates for the time-series model across vendor data sources for each banking organization for the full and the restricted sample of bonds are presented in table 8 . These test statistics were computed using a two equation maximum likelihood technique that employed a weighting matrix composed from an estimate of the residual covariance matrix for both equations. ${ }^{55}$ This estimation technique allowed for the possibility that there may be covariance in the error terms from the time-series model estimated using alternative data sources. As with the likelihood ratio test statistics discussed above, such statistics are asymptotically distributed as Chi-squared divided by degrees

\footnotetext{
${ }^{55}$ One equation is for Bloomberg spreads and the other equation is for IDC spreads. Each equation has the specification of the time series model described above.
} 
Table 8.

Likelihood Ratio (LR) Test Statistics, Equality of Parameter Estimates Using Alternative Data Sources ${ }^{1}$

\begin{tabular}{|c|c|c|c|c|}
\hline \multirow[t]{2}{*}{ Banking Organization Name } & \multicolumn{2}{|c|}{$\begin{array}{l}\text { Full Sample, No Restrictions on Age of } \\
\text { Bonds or Issuance Size }\end{array}$} & \multicolumn{2}{|c|}{\begin{tabular}{|c|} 
Restricted Sample, Bonds Issued Within \\
the Last Three Years with Issuance Size \\
Greater than $\$ 150$ million
\end{tabular}} \\
\hline & Test Statistic ${ }^{2}$ & $\begin{array}{l}\text { Critical Value } \\
\text { DF } 24\end{array}$ & Test Statistic ${ }^{2}$ & $\begin{array}{l}\text { Critical Value } \\
\text { DF } 24 \\
\end{array}$ \\
\hline Amsouth & 49.76 & 36.4 & & \\
\hline Bank America & 894.98 & 36.4 & 166.66 & 36.4 \\
\hline \multicolumn{5}{|l|}{ Bank of New York } \\
\hline Bank of Boston & 860.56 & 36.4 & 860.52 & 36.4 \\
\hline Citicorp & 858.06 & 36.4 & 183.90 & 36.4 \\
\hline Comerica & 210.99 & 36.4 & 105.88 & 36.4 \\
\hline Chase & 1416.80 & 36.4 & 148.05 & 36.4 \\
\hline Fleet & 192.29 & 36.4 & 184.13 & 36.4 \\
\hline First Union & 602.74 & 36.4 & & \\
\hline JP Morgan & 343.10 & 36.4 & 104.12 & 36.4 \\
\hline Keybank & 185.06 & 36.4 & 99.88 & 36.4 \\
\hline Mellon & 245.33 & 36.4 & 39.98 & 36.4 \\
\hline First Amer Bk Corp & 77.64 & 36.4 & 910.13 & 36.4 \\
\hline Banc One & 402.16 & 36.4 & 168.71 & 36.4 \\
\hline PNC & 127.07 & 36.4 & 71.42 & 36.4 \\
\hline Regions Financial Corp & 118.96 & 36.4 & & \\
\hline Republic New York & 512.04 & 36.4 & & \\
\hline Southtrust & 252.13 & 36.4 & & \\
\hline Suntrust & 122.39 & 36.4 & & \\
\hline Union Planters & 116.84 & 36.4 & & \\
\hline US Bank NA & 36.08 & 36.4 & 123.32 & 36.4 \\
\hline Wachovia & 20.75 & 36.4 & 146.22 & 36.4 \\
\hline Wells Fargo & 285.04 & 36.4 & 80.88 & 36.4 \\
\hline $\begin{array}{l}\text { Proportion of banks with } \\
\text { statistically significant LR } \\
\text { differences }\end{array}$ & 0.91 & & 1.00 & \\
\hline \multicolumn{5}{|c|}{$\begin{array}{l}{ }^{1} \text { Test statistics are asymptotically distributed as Chi-squared divided by degrees of freedom (DF), where DF is the number of restrictions tested. } \\
\text { The critical values are for Chi-squared/DF. Tests where the null hypothesis that parameter estimates are equal is not accepted are indicated in } \\
\text { bold face type as are banking organizations classified as LCBO's by banking supervisors as of December 31, } 1998 \text {. }\end{array}$} \\
\hline
\end{tabular}


of freedom. In this application of the test, degrees of freedom equaled the number of parameter estimates that were restricted to be equal across the two equations, which was 24 . For almost every banking organization included in our sample, the null hypothesis that all of the parameter estimates for the time-series model were equal across the IDC and Bloomberg data sources was not accepted. $^{56}$ This was true for both the full sample of bonds as well as the restricted sample of bonds.

To ascertain which parameter estimates were statistically different across data sources, we estimated a "stacked data time-series model." That is, we created a combined data set for each banking organization that stacked it's Bloomberg data set above it's IDC data set (for each day) so that the combined data set could be used to estimate an expanded time-series model. The "stacked data time-series model" for each banking organization has as the dependent variable the stacked Bloomberg and IDC subordinated debt spreads. The explanatory variables include the original set of explanatory variables (i.e., four lags of the banking organization's subordinated debt spread, the contemporaneous one-year Treasury yield with its four lags, the contemporaneous ten-year Treasury yield with its four lags, and the contemporaneous market excess return with its four lags) and each of those explanatory variables interacted with an indicator variable that equals one if the spread is an IDC spread and zero if the spread is a Bloomberg spread. With this specification, the parameter estimates on the explanatory variables that are interacted with the indicator variable are significant only when the individual parameter estimates for the original time-series model are statistically different when IDC data, rather than Bloomberg data, are used.

Parameter estimates for the "stacked data time-series model" for the full sample, which does not place restrictions on the age of the bonds and their issuance size, are presented in tables 9A and 9B. ${ }^{57}$ Importantly, there are many more cases than chance alone would imply where the parameter estimate for an explanatory variable interacted with the IDC indicator variable is statistically significant. Looking across each row, there also appears to be no

\footnotetext{
${ }^{56}$ Test statistics where the null hypothesis was not accepted are in bold face type.

${ }^{57}$ The format for these tables is the same as the format for tables $4 \mathrm{~A}$ and $4 \mathrm{~B}$. The significance of each parameter estimate, with a five percent level of confidence, is indicated with an asterisk $\left(^{*}\right)$ next to the parameter and also by the entry being left-justified within the column of placement.
} 
Table 9A.

Parameter Estimates for "Stacked Data Time-Series Model" Using Alternative Data Sources (I = Interactive Data Corporation (IDC), B = Bloomberg) ${ }^{1}$ Full Sample, no Restrictions on Age of Bonds or Issuance Size

\begin{tabular}{|c|c|c|c|c|c|c|c|c|c|c|c|c|}
\hline \multirow[b]{2}{*}{$\begin{array}{l}\text { Explanatory } \\
\text { Variables }\end{array}$} & \multirow[b]{2}{*}{$\begin{array}{l}\text { Time } \\
\text { Period }\end{array}$} & \multicolumn{11}{|c|}{ Banking Organization } \\
\hline & & Amsouth & $\begin{array}{l}\text { Bank } \\
\text { America }\end{array}$ & $\begin{array}{l}\text { Bank of } \\
\text { New York }\end{array}$ & $\begin{array}{l}\text { Bank of } \\
\text { Boston }\end{array}$ & Citicorp & Comerica & Chase & Fleet & \begin{tabular}{|l} 
First \\
Union
\end{tabular} & $\begin{array}{l}\text { JP } \\
\text { Morgan }\end{array}$ & Keybank \\
\hline \multirow{4}{*}{$\begin{array}{l}\text { Subordinated Debt } \\
\text { Spreads }\end{array}$} & -1 & $0.92 *$ & $0.68^{*}$ & $0.92 *$ & 1.64 & $0.59^{*}$ & $0.89^{*}$ & $0.74 *$ & $0.46^{*}$ & $0.65^{*}$ & $0.70^{*}$ & $0.91 *$ \\
\hline & -2 & 0.10 & $0.15^{*}$ & -0.03 & -1.36 & $0.12 *$ & $0.16^{*}$ & 0.05 & $0.17 *$ & $0.14 *$ & 0.04 & -0.15 \\
\hline & -3 & -0.04 & $0.07 *$ & 0.06 & 1.57 & $0.12 *$ & -0.05 & $0.12 *$ & $0.19^{*}$ & $0.14 *$ & $0.13 *$ & $0.23 *$ \\
\hline & -4 & -0.01 & $0.08^{*}$ & -0.02 & -0.61 & $0.10^{*}$ & -0.02 & 0.04 & $0.15^{*}$ & $0.05^{*}$ & $0.11 *$ & -0.03 \\
\hline \multirow{4}{*}{$\begin{array}{l}\text { Subordinated Debt } \\
\text { Spreads Interacted } \\
\text { with the IDC } \\
\text { Indicator Variable }\end{array}$} & -1 & -0.11 & $0.16^{*}$ & -0.03 & -2.08 & $0.12 *$ & -0.08 & $-0.07 *$ & $0.45^{*}$ & $0.15^{*}$ & $0.14^{*}$ & $-0.20^{*}$ \\
\hline & -2 & 0.00 & $-0.18 *$ & -0.06 & 2.06 & -0.06 & $-0.21 *$ & 0.05 & $-0.31 *$ & $-0.14 *$ & -0.09 & $0.29 *$ \\
\hline & -3 & 0.32 & 0.05 & 0.04 & -1.83 & 0.01 & $0.27^{*}$ & -0.02 & -0.13 & -0.09 & -0.07 & $-0.30^{*}$ \\
\hline & -4 & -0.20 & -0.03 & 0.03 & 0.74 & -0.04 & 0.02 & 0.04 & -0.03 & $0.08^{*}$ & 0.02 & $0.25 *$ \\
\hline \multirow{5}{*}{$\begin{array}{l}\text { Market Leverage } \\
\text { Ratios }\end{array}$} & 0 & -0.03 & \begin{tabular}{|l|}
$-0.02 *$ \\
\end{tabular} & 0.02 & 0.18 & $0.02^{*}$ & \begin{tabular}{|c|}
-0.04 \\
\end{tabular} & 0.02 & $-0.05^{*}$ & 0.02 & -0.00 & $-0.07^{*}$ \\
\hline & -1 & $0.06 *$ & $0.02 *$ & 0.02 & -0.21 & $0.03 *$ & 0.04 & -0.02 & 0.03 & -0.00 & 0.00 & 0.09 \\
\hline & -2 & -0.04 & $-0.01 *$ & $0.07 *$ & -0.08 & $-0.02 *$ & $-0.11^{*}$ & -0.01 & 0.04 & 0.01 & -0.01 & $0.12 *$ \\
\hline & -3 & 0.04 & $0.02 *$ & $-0.08^{*}$ & 0.10 & 0.01 & 0.02 & 0.03 & -0.02 & $-0.04 *$ & 0.02 & $-0.21^{*}$ \\
\hline & -4 & -0.05 & $-0.01 *$ & $-0.04 *$ & -0.27 & $-0.02 *$ & $0.08^{*}$ & $-0.02^{*}$ & -0.05 & $0.03 *$ & 0.00 & $0.07 *$ \\
\hline \multirow{5}{*}{$\begin{array}{l}\text { Market Leverage } \\
\text { Ratios Interacted } \\
\text { with the IDC } \\
\text { Indicator Variable }\end{array}$} & 0 & 0.01 & | $0.04 *$ & -0.02 & 0.33 & $0.04 *$ & 0.02 & 0.01 & 0.03 & 0.02 & $-0.04 *$ & $0.12 *$ \\
\hline & -1 & -0.03 & $-0.06^{*}$ & -0.03 & 0.32 & $-0.04 *$ & 0.06 & 0.01 & 0.03 & -0.01 & 0.01 & $-0.17^{*}$ \\
\hline & -2 & 0.02 & $0.05^{*}$ & 0.05 & 0.21 & -0.02 & -0.01 & $-0.05^{*}$ & $-0.11^{*}$ & $-0.06^{*}$ & $0.05^{*}$ & -0.11 \\
\hline & -3 & -0.05 & $-0.03^{*}$ & -0.03 & -0.21 & $-0.02 *$ & -0.04 & 0.03 & -0.13 & $0.05^{*}$ & -0.03 & $0.19 *$ \\
\hline & -4 & 0.05 & -0.00 & 0.01 & -0.32 & $0.02^{*}$ & -0.00 & -0.01 & $0.22 *$ & -0.02 & -0.00 & -0.02 \\
\hline \multirow{5}{*}{$\begin{array}{l}\text { One Year Treasury } \\
\text { Rates }\end{array}$} & 0 & $0.27^{*}$ & $-0.08^{*}$ & 0.00 & 0.59 & -0.08 & $-0.33^{*}$ & $-0.37^{*}$ & $-0.28^{*}$ & $-0.15^{*}$ & \begin{tabular}{|c|}
-0.09 \\
\end{tabular} & $-0.13^{*}$ \\
\hline & -1 & -0.15 & $-0.16^{*}$ & -0.04 & -1.69 & 0.04 & $0.26^{*}$ & $0.11 *$ & 0.05 & $-0.22 *$ & -0.06 & 0.16 \\
\hline & -2 & -0.21 & $0.14 *$ & $-0.10^{*}$ & 1.72 & 0.07 & 0.08 & $0.20^{*}$ & $0.31^{*}$ & $0.31^{*}$ & $0.16^{*}$ & 0.03 \\
\hline & -3 & -0.06 & $-0.07^{*}$ & $0.11 *$ & -1.18 & $-0.17 *$ & $-0.13 *$ & $-0.18^{*}$ & $-0.27 *$ & $-0.11 *$ & $-0.23 *$ & -0.14 \\
\hline & -4 & 0.15 & $0.11 *$ & -0.03 & 0.06 & 0.06 & 0.04 & $0.19^{*}$ & 0.12 & $0.14^{*}$ & $0.16^{*}$ & 0.07 \\
\hline \multirow{5}{*}{$\begin{array}{l}\text { One Year Treasury } \\
\text { Rates Interacted with } \\
\text { the IDC Indicator } \\
\text { Variable }\end{array}$} & 0 & -0.15 & $-0.09^{*}$ & $-0.20^{*}$ & -1.43 & $0.18^{*}$ & 0.12 & $0.12^{*}$ & 0.12 & 0.03 & -0.13 & -0.01 \\
\hline & -1 & 0.22 & $0.21 *$ & $0.15^{*}$ & 1.17 & -0.05 & -0.03 & -0.01 & -0.00 & $0.32 *$ & $0.22 *$ & -0.15 \\
\hline & -2 & -0.01 & $-0.13^{*}$ & -0.01 & 0.21 & $-0.41^{*}$ & -0.14 & -0.09 & $-0.45^{*}$ & $-0.30^{*}$ & -0.16 & -0.01 \\
\hline & -3 & -0.15 & $0.12^{*}$ & 0.07 & 0.56 & $0.21^{*}$ & 0.09 & $0.14^{*}$ & $0.48 *$ & 0.12 & $0.26^{*}$ & 0.22 \\
\hline & -4 & 0.06 & $-0.09 *$ & -0.02 & -1.53 & $0.12^{*}$ & -0.01 & $-0.13 *$ & -0.13 & $-0.13^{*}$ & -0.12 & -0.04 \\
\hline \multirow{5}{*}{$\begin{array}{l}\text { Ten Year Treasury } \\
\text { Rates }\end{array}$} & 0 & $-0.37 *$ & $-0.10^{*}$ & $-0.08^{*}$ & -0.47 & -0.01 & 0.08 & $0.08^{*}$ & 0.13 & $-0.07^{*}$ & $\begin{array}{ll}-0.02 \\
\end{array}$ & 0.03 \\
\hline & -1 & $0.29 *$ & $0.17^{*}$ & 0.04 & 2.05 & -0.02 & -0.08 & 0.02 & -0.03 & $0.25 *$ & 0.04 & -0.14 \\
\hline & -2 & $0.23 *$ & $-0.07^{*}$ & 0.04 & -2.56 & 0.01 & -0.04 & $-0.11^{*}$ & $-0.26 *$ & $-0.20^{*}$ & $-0.15^{*}$ & 0.00 \\
\hline & -3 & -0.11 & $0.06^{*}$ & -0.04 & 0.79 & 0.06 & 0.08 & $0.13 *$ & $0.34 *$ & $0.14 *$ & $0.22 *$ & 0.12 \\
\hline & -4 & -0.03 & -0.04 & $0.05^{*}$ & 0.26 & 0.00 & 0.02 & $-0.09 *$ & -0.10 & $-0.11 *$ & -0.06 & -0.02 \\
\hline \multirow{5}{*}{$\begin{array}{l}\text { Ten Year Treasury } \\
\text { Rates Interacted with } \\
\text { the IDC Indicator } \\
\text { Variable }\end{array}$} & 0 & 0.05 & 0.05 & 0.07 & 2.11 & $-0.10^{*}$ & -0.09 & $-0.18^{*}$ & -0.10 & 0.02 & 0.02 & -0.05 \\
\hline & -1 & -0.12 & $-0.12 *$ & -0.02 & -2.79 & 0.02 & -0.00 & 0.08 & -0.00 & $-0.27^{*}$ & -0.13 & 0.20 \\
\hline & -2 & -0.06 & $0.10^{*}$ & 0.00 & -0.02 & $0.18^{*}$ & 0.13 & 0.08 & $0.43^{*}$ & $0.23 *$ & $0.16^{*}$ & -0.09 \\
\hline & -3 & $0.35^{*}$ & $-0.13^{*}$ & -0.07 & 0.38 & -0.06 & -0.04 & $-0.12^{*}$ & $-0.48^{*}$ & $-0.14 *$ & $-0.27 *$ & -0.15 \\
\hline & -4 & -0.21 & $0.09 *$ & 0.04 & 1.26 & -0.07 & -0.03 & $0.13^{*}$ & 0.13 & $0.15^{*}$ & $0.17 *$ & 0.08 \\
\hline \multirow{5}{*}{$\begin{array}{l}\text { Stock Market Excess } \\
\text { Returns }\end{array}$} & 0 & $-3.81 *$ & $-1.67 *$ & -0.51 & -5.98 & -0.80 & $-1.83^{*}$ & 0.21 & -1.19 & -0.15 & $-3.60 *$ & $-4.13 *$ \\
\hline & -1 & -2.29 & $-2.26^{*}$ & $1.43^{*}$ & -8.69 & $-2.12 *$ & $-1.61^{*}$ & $-4.14 *$ & $-2.99^{*}$ & $-2.71^{*}$ & $-5.08^{*}$ & -2.48 \\
\hline & -2 & 0.86 & $-2.57 *$ & -0.48 & -5.74 & $-2.09 *$ & $-3.23^{*}$ & $-2.53^{*}$ & $-3.02 *$ & $-2.23^{*}$ & $-4.03 *$ & $2.93^{*}$ \\
\hline & -3 & -1.32 & $-0.86^{*}$ & 0.78 & -5.14 & 0.06 & -0.84 & 0.85 & -1.23 & -0.81 & -1.38 & $-4.89^{*}$ \\
\hline & -4 & -0.13 & $-1.40^{*}$ & -0.77 & -19.81 & -0.49 & -0.11 & $-0.97^{*}$ & -1.67 & $-1.89 *$ & $-1.63 *$ & $-2.56^{*}$ \\
\hline \multirow{5}{*}{$\begin{array}{l}\text { Stock Market Excess } \\
\text { Returns Interacted } \\
\text { with the IDC } \\
\text { Indicator Variable }\end{array}$} & 0 & 2.98 & \begin{tabular}{|c|}
-0.53 \\
\end{tabular} & 0.17 & 18.88 & 1.20 & \begin{tabular}{|c|}
-0.03 \\
\end{tabular} & 0.08 & $-6.03 *$ & -0.77 & \begin{tabular}{|l|} 
\\
\end{tabular} & 1.83 \\
\hline & -1 & 0.76 & -0.33 & -1.22 & 56.15 & 0.92 & 1.35 & $2.82 *$ & 3.28 & 1.23 & 0.64 & 0.32 \\
\hline & -2 & -0.03 & $4.17^{*}$ & 1.07 & 25.54 & $3.11^{*}$ & 1.42 & 0.96 & 3.45 & $2.40^{*}$ & $5.22 *$ & -3.09 \\
\hline & -3 & 1.09 & 0.88 & $-1.84 *$ & 13.31 & -0.42 & -0.66 & -1.30 & -2.49 & 0.49 & -0.22 & 3.56 \\
\hline & -4 & 0.69 & -0.25 & -0.12 & 0.88 & -0.66 & 0.98 & -1.32 & 0.56 & 0.45 & -0.23 & 1.09 \\
\hline $\mathrm{R}^{2}$ & & 0.966 & 0.939 & 0.944 & 0.969 & 0.947 & 0.966 & 0.906 & 0.918 & 0.948 & 0.947 & 0.936 \\
\hline
\end{tabular}


Table 9B.

Parameter Estimates for "Stacked Data Time-Series Model" Using Alternative Data Sources (I = Interactive Data Corporation (IDC), B = Bloomberg) ${ }^{1}$

Full Sample, no Restrictions on Age of Bonds or Issuance Size

\begin{tabular}{|c|c|c|c|c|c|c|c|c|c|c|c|c|c|}
\hline \multirow[b]{2}{*}{$\begin{array}{l}\text { Explanatory } \\
\text { Variables }\end{array}$} & \multirow[b]{2}{*}{$\begin{array}{l}\text { Time } \\
\text { Period }\end{array}$} & \multicolumn{12}{|c|}{ Banking Organization } \\
\hline & & Mellon & \begin{tabular}{|l|} 
First Amer \\
Bk Corp
\end{tabular} & Banc One & PNC & \begin{tabular}{|l|} 
Regions \\
Financial \\
Corporation
\end{tabular} & \begin{tabular}{|l|l} 
Republic \\
New York
\end{tabular} & Southtrust & Suntrust & $\begin{array}{l}\text { Union } \\
\text { Planters }\end{array}$ & $\begin{array}{l}\text { US Bank } \\
\text { NA }\end{array}$ & Wachovia & $\begin{array}{l}\text { Wells } \\
\text { Fargo }\end{array}$ \\
\hline \multirow{4}{*}{$\begin{array}{l}\text { Subordinated Debt } \\
\text { Spreads }\end{array}$} & -1 & $0.64^{*}$ & $0.77^{*}$ & $0.65^{*}$ & $0.66^{*}$ & $0.86^{*}$ & $0.88^{*}$ & $0.79^{*}$ & $0.79^{*}$ & $0.29^{*}$ & $0.56^{*}$ & $0.62^{*}$ & $0.73^{*}$ \\
\hline & -2 & $0.21 *$ & $0.30^{*}$ & $0.23 *$ & $0.23^{*}$ & 0.20 & 0.05 & 0.18 & 0.19 & 0.06 & -0.09 & $0.19 *$ & $0.15^{*}$ \\
\hline & -3 & 0.13 & -0.06 & 0.03 & 0.12 & 0.13 & -0.02 & 0.01 & 0.03 & $0.56^{*}$ & $0.33^{*}$ & 0.11 & 0.03 \\
\hline & -4 & -0.02 & -0.13 & 0.07 & -0.08 - & $-0.29 *$ & 0.03 & -0.06 & -0.01 & 0.04 & 0.12 & 0.07 & 0.03 \\
\hline \multirow{4}{*}{$\begin{array}{l}\text { Subordinated Debt } \\
\text { Spreads Interacted } \\
\text { with the IDC Indicator } \\
\text { Variable }\end{array}$} & -1 & 0.09 & -0.07 & 0.06 & 0.11 - & $-0.36^{*}$ & $-0.16^{*}$ & \begin{tabular}{c|c|}
-0.10 \\
\end{tabular} & 0.00 & $0.40^{*}$ & 0.31 & 0.09 & -0.02 \\
\hline & -2 & -0.16 & -0.13 & -0.11 & -0.13 & -0.07 & 0.04 & -0.22 & 0.00 & 0.14 & 0.31 & 0.09 & -0.03 \\
\hline & -3 & -0.05 & 0.16 & 0.00 & 0.05 & $0.06 \mid 0$ & $0.15^{*}$ & 0.05 & -0.07 & $-0.51^{*}$ & $-0.63^{*}$ & -0.14 & 0.04 \\
\hline & -4 & 0.15 & 0.08 & 0.06 & -0.05 & 0.26 & \begin{tabular}{l|l}
-0.02 & 0 \\
\end{tabular} & $0.27^{*}$ & 0.06 & -0.06 & 0.07 & -0.04 & 0.03 \\
\hline \multirow{5}{*}{$\begin{array}{l}\text { Market Leverage } \\
\text { Ratios }\end{array}$} & 0 & $0.12^{*}$ & \begin{tabular}{l|l}
0.05 & 0 \\
\end{tabular} & $0.02 *$ & -0.01 & \begin{tabular}{l|l}
0.08 & 0 \\
\end{tabular} & $0.06^{*}$ & \begin{tabular}{l|l|}
-0.02 \\
\end{tabular} & $0.06^{*}$ & \begin{tabular}{c|}
-0.06 \\
\end{tabular} & $\begin{array}{l}-0.06 \\
\end{array}$ & \begin{tabular}{c|}
-0.00 \\
\end{tabular} & -0.01 \\
\hline & -1 & -0.05 & $\begin{array}{lll}0.04 & 0\end{array}$ & $0.04 *$ & 0.11 & $-0.07-$ & $-0.07^{*}$ & 0.05 & -0.04 & 0.04 & $0.17^{*}$ & 0.05 & 0.01 \\
\hline & -2 & -0.07 & $-0.07 \mid-$ & $-0.06^{*}$ & -0.09 & -0.03 & 0.01 & 0.02 & -0.02 & 0.09 & $-0.39 *$ & $-0.10^{*}$ & -0.00 \\
\hline & -3 & 0.03 & -0.06 & 0.01 & $-0.12 *$ & 0.12 & -0.02 & 0.06 & 0.01 & -0.00 & 0.18 & 0.03 & -0.03 \\
\hline & -4 & -0.04 & 0.05 & $-0.04 *$ & $0.08^{*}$ & -0.08 & $0.01-$ & $-0.09 *$ & -0.02 & -0.05 & 0.02 & 0.01 & 0.03 \\
\hline \multirow{5}{*}{$\begin{array}{l}\text { Market Leverage } \\
\text { Ratios Interacted with } \\
\text { the IDC Indicator } \\
\text { Variable }\end{array}$} & 0 & \begin{tabular}{l|l}
0.07 \\
\end{tabular} & \begin{tabular}{l|l}
0.04 & 0 \\
\end{tabular} & $0.06^{*}$ & 0.08 & -0.04 & \begin{tabular}{|c|}
-0.03 \\
\end{tabular} & 0.01 & $0.12^{*}$ & 0.14 & -0.03 & -0.07 & $0.04 *$ \\
\hline & -1 & -0.16 & -0.13 & $-0.04 *$ & -0.10 & -0.00 & 0.04 & -0.01 & $-0.13 *$ & -0.13 & 0.02 & 0.06 & -0.02 \\
\hline & -2 & 0.03 & 0.10 & $-0.04 *$ & -0.02 & 0.02 & 0.00 & $-0.13^{*}$ & -0.05 & -0.11 & 0.15 & -0.00 & -0.04 \\
\hline & -3 & -0.12 & -0.03 & -0.02 & $0.23^{*}$ & -0.04 & 0.00 & 0.11 & 0.04 & 0.04 & -0.09 & -0.01 & 0.01 \\
\hline & -4 & $0.18^{*}$ & $\begin{array}{lll}0.01 & 0 \\
\end{array}$ & $0.04 *$ & $-0.18^{*}$ & 0.07 & -0.01 & 0.02 & -0.00 & 0.04 & -0.01 & 0.01 & -0.01 \\
\hline \multirow{5}{*}{$\begin{array}{l}\text { One Year Treasury } \\
\text { Rates }\end{array}$} & 0 & \begin{tabular}{c|}
-0.09 \\
\end{tabular} & $0.19^{*}$ & 0.01 & -0.05 & \begin{tabular}{|c|}
-0.03 \\
\end{tabular} & \begin{tabular}{l|l}
-0.00 & 0
\end{tabular} & $0.17^{*}$ & 0.05 & $-0.27 *$ & $-0.28^{*}$ & 0.06 & 0.02 \\
\hline & -1 & $0.15^{*}$ & -0.09 & -0.00 & 0.08 & -0.06 & -0.02 & -0.04 & -0.01 & -0.11 & $0.46^{*}$ & -0.01 & $-0.19 *$ \\
\hline & -2 & $-0.25^{*}$ & $-0.35^{*}$ & -0.08 & -0.08 & 0.09 & -0.08 & -0.09 & -0.00 & 0.31 & -0.09 & 0.04 & 0.09 \\
\hline & -3 & -0.06 & 0.09 & $-0.13^{*}$ & $-0.33^{*}$ & \begin{tabular}{l|l}
-0.02 & 0
\end{tabular} & $0.14^{*}$ & 0.00 & -0.11 & 0.00 & $-0.34 *$ & $-0.21^{*}$ & -0.08 \\
\hline & -4 & $0.20 *$ & $\begin{array}{lll}0.05 & 0 \\
\end{array}$ & $0.16^{*}$ & $0.32 *$ & -0.08 & $-0.14^{*}$ & -0.03 & 0.08 & 0.01 & $0.27 *$ & 0.10 & $0.11^{*}$ \\
\hline \multirow{5}{*}{$\begin{array}{l}\text { One Year Treasury } \\
\text { Rates Interacted with } \\
\text { the IDC Indicator } \\
\text { Variable }\end{array}$} & 0 & \begin{tabular}{l|}
-0.06 \\
\end{tabular} & \begin{tabular}{|c|}
-0.03 \\
\end{tabular} & 0.01 & \begin{tabular}{|c|}
-0.04 \\
\end{tabular} & \begin{tabular}{l|l}
-0.03 & 0
\end{tabular} & $0.20^{*}$ & \begin{tabular}{|c|}
-0.10 \\
\end{tabular} & 0.06 & $0.45^{*}$ & -0.26 & 0.04 & $-0.15^{*}$ \\
\hline & -1 & 0.01 & 0.14 & 0.00 & 0.13 & 0.08 & -0.03 & -0.06 & 0.06 & 0.04 & 0.30 & 0.06 & $0.32 *$ \\
\hline & -2 & 0.17 & 0.06 & -0.10 & 0.07 & -0.02 & -0.06 & 0.13 & -0.19 & $-0.51^{*}$ & -0.08 & -0.17 & -0.07 \\
\hline & -3 & 0.02 & -0.19 & 0.06 & 0.15 & $-0.06 \mid-$ & $-0.28^{*}$ & 0.08 & 0.10 & -0.27 & -0.06 & 0.11 & -0.01 \\
\hline & -4 & -0.12 & 0.00 & 0.02 . & $-0.30^{*}$ & \begin{tabular}{ll|l}
0.06 & 0 \\
\end{tabular} & $0.22 *$ & -0.05 & -0.02 & 0.24 & -0.05 & -0.01 & -0.06 \\
\hline \multirow{5}{*}{$\begin{array}{l}\text { Ten Year Treasury } \\
\text { Rates }\end{array}$} & 0 & \begin{tabular}{|c|}
-0.04 \\
\end{tabular} & \begin{tabular}{|c|}
-0.14 \\
\end{tabular} & \begin{tabular}{c|}
-0.00 \\
\end{tabular} & \begin{tabular}{l|l|}
0.04 \\
\end{tabular} & \begin{tabular}{ll|}
$0.03-1$ \\
\end{tabular} & \begin{tabular}{|c|}
$-0.13^{*}$ \\
\end{tabular} & 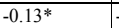 & $\mid-0.15^{*}$ & \begin{tabular}{l|l|}
0.18 \\
\end{tabular} & $0.24^{*}$ & $-0.17^{*}$ & -0.02 \\
\hline & -1 & -0.08 & 0.01 & -0.03 & -0.07 & $\begin{array}{lll}-0.07 & 0\end{array}$ & $0.14^{*}$ & -0.01 & 0.04 & -0.03 & $-0.41^{*}$ & 0.11 & 0.05 \\
\hline & -2 & $0.19 *$ & 0.22 & 0.07 & 0.07 & -0.02 & -0.00 & 0.11 & 0.09 & $-0.42 *$ & 0.11 & 0.01 & -0.03 \\
\hline & -3 & 0.11 & $\begin{array}{lll}-0.07 & 0\end{array}$ & $0.12 *$ & $0.19^{*}$ & 0.00 & $-0.09 *$ & -0.01 & 0.06 & 0.09 & $0.28^{*}$ & $0.13^{*}$ & 0.08 \\
\hline & -4 & -0.15 & $-0.00-$ & $-0.12^{*}$ & $-0.18^{*}$ & \begin{tabular}{l|l}
0.09 & 0 \\
\end{tabular} & $0.12 *$ & -0.00 & -0.05 & 0.17 & $-0.22 *$ & -0.06 & -0.06 \\
\hline \multirow{5}{*}{$\begin{array}{l}\text { Ten Year Treasury } \\
\text { Rates Interacted with } \\
\text { the IDC Indicator } \\
\text { Variable }\end{array}$} & 0 & 0.01 & \begin{tabular}{c|}
-0.04 \\
\end{tabular} & \begin{tabular}{c|}
-0.00 \\
\end{tabular} & 0.05 & \begin{tabular}{l|}
-0.08 \\
\end{tabular} & \begin{tabular}{l|}
-0.08 \\
\end{tabular} & 0.02 & -0.10 & $-0.49^{*}$ & 0.06 & 0.01 & 0.02 \\
\hline & -1 & 0.01 & 0.03 & -0.00 & -0.13 & 0.14 & -0.07 & -0.18 & 0.07 & 0.14 & 0.02 & -0.09 & -0.11 \\
\hline & -2 & -0.11 & -0.09 & 0.07 & -0.09 & -0.06 & 0.08 & $-0.27^{*}$ & 0.09 & $0.61^{*}$ & -0.08 & 0.15 & 0.05 \\
\hline & -3 & -0.12 & 0.15 & -0.09 & -0.09 & 0.01 & 0.09 & -0.08 & -0.11 & 0.10 & 0.10 & -0.09 & -0.05 \\
\hline & -4 & $0.19 *$ & -0.05 & 0.02 & 0.25 & -0.02 & -0.06 & 0.15 & 0.05 & $-0.32 *$ & -0.00 & 0.00 & 0.07 \\
\hline \multirow{5}{*}{$\begin{array}{l}\text { Stock Market Excess } \\
\text { Returns }\end{array}$} & 0 & \begin{tabular}{l|}
-1.49 \\
\end{tabular} & \begin{tabular}{c|}
-0.60 \\
\end{tabular} & \begin{tabular}{l|l}
-0.62 \\
\end{tabular} & \begin{tabular}{l|l}
-1.92 \\
\end{tabular} & \begin{tabular}{l|l|}
1.08 \\
\end{tabular} & $0.71-$ & $-3.61^{*}$ & -0.27 & \begin{tabular}{|c|}
-1.06 \\
\end{tabular} & -2.11 & \begin{tabular}{|c|}
-1.49 \\
\end{tabular} & $-1.59^{*}$ \\
\hline & -1 & $-2.13^{*}$ & -1.22 & $-1.43^{*}$ & -0.13 & $-2.22=$ & $-2.66^{*}$ & -1.38 & $-2.36^{*}$ & $-4.11 *$ & 1.93 & -1.68 & $-1.24 *$ \\
\hline & -2 & -1.80 & -0.72 & $-1.33^{*}$ & -0.86 & -1.97 & -0.15 & -0.29 & -0.03 & -1.53 & $-5.96 *$ & $-3.40^{*}$ & $-1.52 *$ \\
\hline & -3 & -0.17 & -0.50 & -1.14 & $-4.46^{*}$ & 0.89 & -0.98 & 0.20 & 1.37 & $-5.54^{*}$ & 2.77 & -0.61 & $-2.08 *$ \\
\hline & -4 & -0.08 & -0.83 & $-2.15^{*}$ & -2.18 & -0.15 & $-2.20^{*}$ & -1.14 & -0.16 & $-3.65^{*}$ & $-6.24 *$ & -1.09 & $-2.11 *$ \\
\hline \multirow{5}{*}{$\begin{array}{l}\text { Stock Market Excess } \\
\text { Returns Interacted } \\
\text { with the IDC Indicator } \\
\text { Variable }\end{array}$} & 0 & 0.72 & \begin{tabular}{|l|l|}
1.13 \\
\end{tabular} & 0.56 & \begin{tabular}{l|}
1.53 \\
\end{tabular} & \begin{tabular}{l|}
-1.52 \\
\end{tabular} & \begin{tabular}{l|l}
0.09 \\
\end{tabular} & 2.30 & $3.80^{*}$ & 0.34 & -1.21 & $-2.33^{*}$ & -0.21 \\
\hline & -1 & -1.45 & -0.92 & -0.69 & -2.33 & 1.33 & 1.33 & 2.88 & 0.94 & 4.33 & -0.22 & 0.27 & -0.86 \\
\hline & -2 & 0.96 & 1.591 & $1.92 *$ & -1.94 & $2.62 \mid 1$ & $1.92^{*}$ & -3.27 & -0.98 & 0.51 & 3.11 & 1.83 & 1.62 \\
\hline & -3 & -0.13 & 0.84 & 0.50 & $6.54^{*}$ & \begin{tabular}{l|l}
0.17 & 3
\end{tabular} & $3.90^{*}$ & -0.04 & 0.86 & $6.70^{*}$ & 4.57 & 1.32 & 1.33 \\
\hline & -4 & -0.33 & 1.04 & -1.03 & 1.35 & -1.42 & 0.30 & -0.36 & 1.23 & 2.66 & 1.69 & 0.43 & 0.39 \\
\hline $\mathrm{R}^{2}$ & & 0.931 & 0.952 & 0.949 & 0.935 & 0.943 & 0.930 & 0.923 & 0.988 & 0.938 & 0.975 & 0.958 & 0.921 \\
\hline
\end{tabular}


discernable pattern of differences in specific parameter estimates across banking organizations. Moreover, there is only one parameter estimate - for the fourth lag on stock market excess returns -- that is not significantly different across data sources for at least one banking organization in our sample. On balance, these findings suggest that: (1) there are significant differences in the time-series properties of Bloomberg data versus IDC data, and (2) there are significant differences in how each vendor's data responds to banking organization-specific risk measures and to systematic risk factors.

In tables $10 \mathrm{~A}$ and $10 \mathrm{~B}$, the parameter estimates for the "stacked data time-series model" for the restricted sample that contains only bonds issued within the last three years with issuance size greater than $\$ 150$ million are presented. As with the full sample, there are many cases where the parameter estimates of the time-series model are statistically different across data sources, there is no discernable pattern in such differences across banking organizations, and these differences are generally statistically significant for each parameter estimate of the timeseries model for at least one banking organization in the sample. Thus, restricting the characteristics of the bonds analyzed did not reduce the statistical differences in the parameter estimates that resulted from using two alternative data sources.

In sum, the time-series models estimated with Bloomberg and IDC data are statistically different from one another. The Bloomberg data are considerably more noisy than are IDC data even after controlling for banking organization-specific risks and systematic risks, at least for the bonds analyzed. For all of the subsets of variables we considered, each subset was statistically important for most banking organizations, regardless of the source. Nevertheless, the Bloomberg data contained statistically stronger systematic risk factors for term-structure and for stock market excess returns than did the IDC data. Importantly, the data reject the hypothesis that all parameter estimates are jointly equal. Indeed, many of the individual parameter estimates were statistically different when Bloomberg rather than IDC data were used.

The distinctly different empirical findings from the same model estimated using two different vendor data sources suggest that time-series modeling to ascertain the factors that affect subordinated debt spreads for banking organizations may depend critically on the matrix methods used to fill in prices on bonds when transaction prices are not available. Such findings also suggest that interpretation of the time-series movements of subordinated debt spreads will 
Table 10A.

Parameter Estimates for "Stacked Data Time-Series Model" Using Alternative Data Sources (I = Interactive Data Corporation (IDC), B = Bloomberg) $)^{1}$

Restricted Sample, Bonds Issued within the Last 3 Years with Issuance Size Greater than \$150 million

\begin{tabular}{|c|c|c|c|c|c|c|c|c|c|c|c|c|}
\hline \multirow{2}{*}{$\begin{array}{l}\text { Explanatory } \\
\text { Variables }\end{array}$} & \multirow{2}{*}{$\begin{array}{l}\text { Time } \\
\text { Period }\end{array}$} & \multicolumn{11}{|c|}{ Banking Organization } \\
\hline & & Amsouth & \begin{tabular}{|l} 
Bank \\
America
\end{tabular} & \begin{tabular}{|l|} 
Bank of \\
New York
\end{tabular} & $\begin{array}{l}\text { Bank of } \\
\text { Boston }\end{array}$ & Citicorp & Comerica & Chase & Fleet & \begin{tabular}{|l} 
First \\
Union \\
\end{tabular} & \begin{tabular}{|l} 
JP \\
Morgan
\end{tabular} & Keybank \\
\hline \multirow{4}{*}{$\begin{array}{l}\text { Subordinated Debt } \\
\text { Spreads }\end{array}$} & -1 & -- & $0.59^{*}$ & -- & 1.64 & $0.69^{*}$ & $0.58^{*}$ & $0.57^{*}$ & $0.47^{*}$ & -- & $0.78^{*}$ & $0.40^{*}$ \\
\hline & -2 & -- & $0.13 *$ & - & -1.36 & 0.06 & $0.52 *$ & 0.04 & $0.17^{*}$ & -- & -0.04 & -0.06 \\
\hline & -3 & -- & $0.11 *$ & -- & 1.58 & 0.05 & 0.03 & 0.09 & $0.19 *$ & -- & 0.07 & -0.28 \\
\hline & -4 & -- & 0.08 & -- & -0.61 & 0.05 & -0.22 & $0.20 *$ & $0.15^{*}$ & -- & 0.09 & $0.52 *$ \\
\hline \multirow{4}{*}{$\begin{array}{l}\text { Subordinated Debt } \\
\text { Spreads Interacted } \\
\text { with the IDC } \\
\text { Indicator Variable }\end{array}$} & -1 & -- & $0.31^{*}$ & -- & -2.08 & -0.14 & 0.10 & $0.17^{*}$ & $0.41^{*}$ & -- & 0.03 & 0.49 \\
\hline & -2 & -- & $-0.30^{*}$ & -- & 2.06 & -0.20 & $-0.42 *$ & 0.02 & $-0.28 *$ & -- & -0.19 & 0.31 \\
\hline & -3 & -- & -0.10 & -- & -1.83 & 0.24 & 0.17 & 0.01 & -0.10 & -- & 0.16 & -0.26 \\
\hline & -4 & -- & 0.09 & -- & 0.74 & 0.12 & 0.13 & $-0.21 *$ & -0.05 & -- & -0.02 & -0.13 \\
\hline \multirow{5}{*}{$\begin{array}{l}\text { Market Leverage } \\
\text { Ratios }\end{array}$} & 0 & -- & -0.03 & -- & 0.19 & 0.01 & 0.01 & $-0.07^{*}$ & $-0.04 *$ & -- & -0.03 & -0.13 \\
\hline & -1 & -- & 0.03 & -- & -0.21 & -0.03 & 0.03 & $0.09 *$ & 0.02 & -- & -0.01 & 0.26 \\
\hline & -2 & -- & $-0.06^{*}$ & -- & -0.08 & 0.00 & -0.16 & 0.03 & 0.03 & -- & $0.05^{*}$ & 0.00 \\
\hline & -3 & -- & $0.08^{*}$ & -- & 0.10 & -0.01 & 0.04 & $-0.07 *$ & -0.05 & -- & 0.01 & $-0.21 *$ \\
\hline & -4 & -- & -0.02 & -- & -0.27 & 0.02 & 0.06 & 0.00 & -0.03 & -- & -0.02 & 0.11 \\
\hline \multirow{5}{*}{$\begin{array}{l}\text { Market Leverage } \\
\text { Ratios Interacted } \\
\text { with the IDC } \\
\text { Indicator Variable }\end{array}$} & 0 & -- & 0.01 & -- & 0.33 & $0.06^{*}$ & -0.05 & $0.08 *$ & 0.03 & -- & -0.03 & 0.26 \\
\hline & -1 & -- & -0.02 & -- & 0.32 & 0.04 & 0.15 & -0.08 & 0.03 & -- & 0.04 & $-0.40^{*}$ \\
\hline & -2 & -- & $0.08 *$ & -- & 0.21 & $-0.08 *$ & -0.05 & -0.07 & $-0.12 *$ & -- & -0.01 & -0.07 \\
\hline & -3 & -- & $-0.06 *$ & -- & -0.21 & 0.01 & -0.06 & $0.12 *$ & $-0.20^{*}$ & -- & -0.05 & 0.16 \\
\hline & -4 & -- & -0.01 & -- & -0.32 & -0.04 & 0.02 & $-0.07 *$ & $0.30^{*}$ & -- & 0.04 & -0.02 \\
\hline \multirow{5}{*}{$\begin{array}{l}\text { One Year Treasury } \\
\text { Rates }\end{array}$} & 0 & -- & $-0.31 *$ & -- & 0.59 & \begin{tabular}{|c|}
-0.07 \\
\end{tabular} & -0.18 & $-0.33^{*}$ & $-0.28^{*}$ & -- & $-0.61^{*}$ & $-0.41 *$ \\
\hline & -1 & -- & 0.02 & -- & -1.69 & -0.26 & 0.13 & 0.08 & 0.04 & -- & $0.69 *$ & 0.39 \\
\hline & -2 & -- & $0.24 *$ & -- & 1.72 & 0.23 & 0.11 & $0.30^{*}$ & $0.32 *$ & -- & -0.05 & 0.07 \\
\hline & -3 & -- & -0.12 & -- & -1.18 & -0.31 & -0.22 & $-0.40 *$ & $-0.28 *$ & -- & $-0.58^{*}$ & 0.08 \\
\hline & -4 & -- & 0.06 & -- & 0.06 & 0.19 & 0.02 & $0.27 *$ & 0.13 & -- & $0.45^{*}$ & -0.20 \\
\hline \multirow{5}{*}{$\begin{array}{l}\text { One Year Treasury } \\
\text { Rates Interacted } \\
\text { with the IDC } \\
\text { Indicator Variable }\end{array}$} & 0 & -- & 0.17 & -- & \begin{tabular}{|c|}
-1.43 \\
\end{tabular} & 0.25 & 0.14 & $0.23 *$ & 0.06 & -- & $0.39^{*}$ & 0.06 \\
\hline & -1 & -- & -0.13 & -- & 1.17 & 0.11 & -0.08 & -0.17 & 0.05 & -- & $-0.72 *$ & 0.10 \\
\hline & -2 & -- & -0.13 & -- & 0.21 & $-0.70^{*}$ & -0.11 & -0.13 & $-0.48^{*}$ & -- & 0.10 & -0.37 \\
\hline & -3 & -- & $0.27 *$ & -- & 0.56 & 0.32 & 0.17 & $0.33 *$ & $0.51^{*}$ & -- & $0.72 *$ & 0.11 \\
\hline & -4 & -- & -0.17 & -- & -1.53 & 0.08 & -0.10 & $-0.22 *$ & -0.15 & -- & $-0.44 *$ & 0.15 \\
\hline \multirow{5}{*}{$\begin{array}{l}\text { Ten Year Treasury } \\
\text { Rates }\end{array}$} & 0 & -- & $0.13^{*}$ & -- & $\begin{array}{c}-0.47 \\
\end{array}$ & -0.18 & 0.12 & 0.09 & 0.12 & -- & $0.37^{*}$ & $0.41^{*}$ \\
\hline & -1 & -- & -0.07 & -- & 2.06 & $0.26^{*}$ & -0.14 & -0.10 & -0.01 & -- & $-0.59 *$ & $-0.52 *$ \\
\hline & -2 & -- & $-0.15^{*}$ & -- & -2.56 & -0.17 & -0.06 & $-0.20^{*}$ & $-0.28 *$ & -- & 0.10 & -0.39 \\
\hline & -3 & -- & $0.16^{*}$ & - & 0.79 & 0.22 & 0.11 & $0.37 *$ & $0.35^{*}$ & -- & $0.40^{*}$ & 0.10 \\
\hline & -4 & -- & 0.01 & -- & 0.26 & -0.02 & 0.05 & $-0.13^{*}$ & -0.10 & -- & $-0.22 *$ & $0.43 *$ \\
\hline \multirow{5}{*}{$\begin{array}{l}\text { Ten Year Treasury } \\
\text { Rates Interacted } \\
\text { with the IDC } \\
\text { Indicator Variable }\end{array}$} & 0 & -- & -0.12 & -- & 2.12 & -0.01 & -0.15 & $-0.19^{*}$ & -0.09 & -- & $-0.30^{*}$ & -0.28 \\
\hline & -1 & -- & 0.10 & -- & -2.79 & -0.18 & 0.10 & $0.22 *$ & -0.03 & -- & $0.59^{*}$ & 0.41 \\
\hline & -2 & -- & 0.13 & -- & -0.03 & $0.40^{*}$ & 0.06 & 0.03 & $0.47^{*}$ & -- & -0.18 & 0.45 \\
\hline & -3 & -- & $-0.31 *$ & -- & 0.38 & -0.31 & -0.07 & $-0.28 *$ & $-0.49 *$ & -- & $-0.57^{*}$ & -0.31 \\
\hline & -4 & -- & $0.18^{*}$ & -- & 1.26 & 0.04 & 0.02 & $0.20^{*}$ & 0.12 & -- & $0.43 *$ & -0.35 \\
\hline \multirow{5}{*}{$\begin{array}{l}\text { Stock Market } \\
\text { Excess Returns }\end{array}$} & 0 & -- & $-4.25^{*}$ & -- & -5.980 & $\begin{array}{c}-0.360 \\
\end{array}$ & -2.070 & $-4.64 *$ & $\begin{array}{l}-1.690 \\
\end{array}$ & -- & $-7.02 *$ & -6.810 \\
\hline & -1 & -- & $-4.93 *$ & -- & -8.69 & -2.02 & -3.33 & $-4.07 *$ & -2.73 & -- & $-8.78^{*}$ & -0.72 \\
\hline & -2 & -- & $-4.95^{*}$ & - & -5.74 & $-6.80^{*}$ & $-4.74 *$ & -0.07 & $-3.39 *$ & -- & 0.39 & 1.91 \\
\hline & -3 & -- & $-2.15^{*}$ & -- & -5.14 & -3.50 & -1.92 & $-2.81 *$ & -1.82 & -- & -1.17 & $7-10.43 *$ \\
\hline & -4 & -- & -1.39 & -- & -19.81 & -0.26 & -0.40 & $-3.86^{*}$ & -1.52 & -- & -0.67 & -10.52 \\
\hline \multirow{5}{*}{$\begin{array}{l}\text { Stock Market } \\
\text { Excess Returns } \\
\text { Interacted with the } \\
\text { IDC Indicator } \\
\text { Variable }\end{array}$} & 0 & -- & -1.31 & -- & 18.88 & 0.21 & -0.72 & 3.40 & $-6.76^{*}$ & -- & $\begin{array}{c}-0.58 \\
\end{array}$ & 5.95 \\
\hline & -1 & -- & $2.61^{*}$ & -- & 56.15 & 0.98 & 4.26 & 3.04 & 2.38 & -- & 4.12 & 2.57 \\
\hline & -2 & -- & $4.89^{*}$ & -- & 25.54 & $6.27^{*}$ & 2.75 & 0.75 & 2.50 & -- & 0.83 & -6.53 \\
\hline & -3 & - & 1.98 & - & 13.31 & 2.22 & -1.16 & $3.67 *$ & -3.70 & -- & -3.01 & 8.64 \\
\hline & -4 & -- & -0.65 & -- & 0.88 & -1.41 & -1.11 & 2.28 & 0.71 & -- & -1.42 & 3.31 \\
\hline $\mathrm{R}^{2}$ & & -- & 0.918 & -- & 0.969 & 0.927 & 0.934 & 0.919 & 0.895 & -- & 0.934 & 0.952 \\
\hline
\end{tabular}


Table 10B.

Parameter Estimates for "Stacked Data Time-Series Model" Using Alternative Data Sources

(I = Interactive Data Corporation (IDC), B = Bloomberg) ${ }^{1}$

Restricted Sample, Bonds Issued within the Last 3 Years with Issuance Size Greater than \$150 million

\begin{tabular}{|c|c|c|c|c|c|c|c|c|c|c|c|c|c|}
\hline \multirow[b]{2}{*}{$\begin{array}{l}\text { Explanatory } \\
\text { Variables }\end{array}$} & \multirow[b]{2}{*}{$\begin{array}{l}\text { Time } \\
\text { Period }\end{array}$} & \multicolumn{12}{|c|}{ Banking Organization } \\
\hline & & Mellon & \begin{tabular}{|l} 
First Amer \\
Bk Corp
\end{tabular} & Banc One & PNC & \begin{tabular}{|l|} 
Regions \\
Financial \\
Corporation \\
\end{tabular} & $\begin{array}{l}\text { Republic } \\
\text { New York }\end{array}$ & Southtrust & Suntrust & \begin{tabular}{|l} 
Union \\
Planters
\end{tabular} & $\begin{array}{l}\text { US Bank } \\
\text { NA }\end{array}$ & Wachovia & $\begin{array}{l}\text { Wells } \\
\text { Fargo }\end{array}$ \\
\hline \multirow{4}{*}{$\begin{array}{l}\text { Subordinated Debt } \\
\text { Spreads }\end{array}$} & -1 & $0.57^{*}$ & -0.06 & $0.53 *$ & $0.58 *$ & -- & -- & -- & -- & -- & 0.29 & $0.30^{*}$ & 0.34 \\
\hline & -2 & 0.32 & 0.49 & $0.22 *$ & 0.14 & - & -- & -- & -- & -- & -0.18 & 0.04 & -0.17 \\
\hline & -3 & 0.02 & -0.84 & $0.18^{*}$ & 0.12 & -- & -- & -- & -- & -- & 0.45 & $0.22 *$ & 0.17 \\
\hline & -4 & -0.10 & 0.42 & 0.04 & 0.05 & -- & -- & -- & -- & -- & -0.15 & 0.16 & 0.12 \\
\hline \multirow{4}{*}{$\begin{array}{l}\text { Subordinated Debt } \\
\text { Spreads Interacted } \\
\text { with the IDC } \\
\text { Indicator Variable }\end{array}$} & -1 & 0.21 & 1.29 & 0.11 & 0.31 & - & - & - & -- & -- & 0.19 & 0.24 & -0.08 \\
\hline & -2 & -0.58 & -0.56 & -0.02 & -0.17 & -- & -- & - & -- & -- & 0.05 & -0.07 & 0.14 \\
\hline & -3 & 0.18 & 3.29 & -0.17 & 0.08 & - & -- & - & - & -- & -0.28 & -0.17 & -0.22 \\
\hline & -4 & 0.09 & -0.86 & 0.08 & -0.21 & -- & -- & -- & -- & -- & 0.50 & 0.03 & 0.18 \\
\hline \multirow{5}{*}{$\begin{array}{l}\text { Market Leverage } \\
\text { Ratios }\end{array}$} & 0 & 0.27 & 0.32 & $0.04 *$ & 0.00 & -- & -- & -- & -- & -- & 0.08 & 0.05 & 0.03 \\
\hline & -1 & -0.05 & 0.62 & 0.01 & 0.15 & -- & -- & -- & -- & -- & 0.25 & 0.17 & -0.03 \\
\hline & -2 & -0.50 & 0.08 & -0.04 & -0.15 & -- & -- & -- & -- & -- & -0.54 & $-0.37 *$ & -0.01 \\
\hline & -3 & 0.13 & -0.28 & -0.00 & $-0.21 *$ & -- & -- & -- & -- & -- & -0.40 & 0.05 & -0.12 \\
\hline & -4 & 0.29 & -0.29 & $-0.04 *$ & $0.18 *$ & -- & -- & -- & -- & -- & 0.24 & 0.08 & 0.14 \\
\hline \multirow{5}{*}{$\begin{array}{l}\text { Market Leverage } \\
\text { Ratios Interacted } \\
\text { with the IDC } \\
\text { Indicator Variable }\end{array}$} & 0 & 0.01 & -0.04 & 0.04 & 0.13 & -- & -- & -- & -- & -- & 0.16 & $-0.47 *$ & -0.00 \\
\hline & -1 & -0.15 & -0.23 & -0.02 & -0.22 & -- & -- & -- & -- & -- & -0.17 & -0.02 & 0.03 \\
\hline & -2 & 0.34 & -1.08 & -0.10 & 0.05 & -- & -- & -- & -- & -- & 0.36 & 0.14 & -0.04 \\
\hline & -3 & -0.36 & 0.02 & 0.00 & 0.17 & - & -- & -- & -- & -- & 0.72 & -0.01 & 0.07 \\
\hline & -4 & 0.24 & 0.32 & $0.07 *$ & -0.10 & -- & -- & -- & -- & -- & -0.72 & -0.01 & -0.08 \\
\hline \multirow{5}{*}{$\begin{array}{l}\text { One Year Treasury } \\
\text { Rates }\end{array}$} & 0 & $-0.55^{*}$ & -0.78 & -0.07 & -0.15 & -- & -- & -- & -- & -- & -0.21 & 0.21 & -0.2 \\
\hline & -1 & $0.73^{*}$ & 0.30 & 0.06 & 0.03 & -- & -- & -- & -- & -- & $0.98^{*}$ & $-0.26^{*}$ & -0.24 \\
\hline & -2 & -0.31 & $-0.55^{*}$ & 0.03 & -0.08 & -- & -- & -- & -- & -- & $-0.99 *$ & $0.29^{*}$ & 0.26 \\
\hline & -3 & -0.38 & 0.23 & $-0.33 *$ & $-0.41^{*}$ & -- & -- & - & -- & -- & 0.47 & $-0.56^{*}$ & -0.24 \\
\hline & -4 & 0.38 & -0.11 & $0.23 *$ & $0.45^{*}$ & -- & -- & -- & -- & -- & -0.45 & 0.04 & -0.14 \\
\hline \multirow{5}{*}{$\begin{array}{l}\text { One Year Treasury } \\
\text { Rates Interacted with } \\
\text { the IDC Indicator } \\
\text { Variable }\end{array}$} & 0 & 0.33 & $0.98 *$ & 0.10 & 0.14 & -- & -- & -- & -- & -- & $\begin{array}{c}-0.09 \\
\end{array}$ & 0.08 & -0.47 \\
\hline & -1 & -0.30 & -0.31 & -0.21 & 0.07 & -- & -- & -- & -- & -- & -0.72 & 0.13 & 0.36 \\
\hline & -2 & -0.12 & -0.31 & -0.19 & 0.03 & - & - & - & -- & - & 0.94 & $-0.49 *$ & -0.13 \\
\hline & -3 & 0.55 & -0.67 & $0.32 *$ & 0.22 & -- & -- & -- & -- & -- & -0.83 & $0.75^{*}$ & 0.16 \\
\hline & -4 & -0.55 & 0.37 & -0.03 & $-0.43 *$ & -- & -- & -- & -- & -- & 0.35 & -0.12 & 0.11 \\
\hline \multirow{5}{*}{$\begin{array}{l}\text { Ten Year Treasury } \\
\text { Rates }\end{array}$} & 0 & 0.18 & 0.16 & 0.04 & 0.03 & -- & -- & -- & -- & -- & 0.25 & $-0.34^{*}$ & -0.12 \\
\hline & -1 & $-0.47 *$ & 0.18 & -0.06 & -0.08 & -- & -- & -- & -- & -- & $-0.46^{*}$ & $0.27^{*}$ & 0.28 \\
\hline & -2 & $0.46^{*}$ & -0.13 & -0.04 & 0.11 & -- & -- & -- & -- & -- & 0.40 & -0.20 & -0.13 \\
\hline & -3 & 0.25 & 0.16 & $0.28 *$ & $0.32 *$ & -- & -- & -- & -- & -- & -0.44 & $0.43^{*}$ & 0.17 \\
\hline & -4 & -0.34 & -0.14 & $-0.18^{*}$ & $-0.27^{*}$ & -- & -- & -- & -- & -- & 0.50 & 0.03 & 0.16 \\
\hline \multirow{5}{*}{$\begin{array}{l}\text { Ten Year Treasury } \\
\text { Rates Interacted with } \\
\text { the IDC Indicator } \\
\text { Variable }\end{array}$} & 0 & -0.32 & 0.13 & -0.08 & -0.13 & -- & -- & -- & -- & -- & -0.14 & 0.07 & 0.33 \\
\hline & -1 & 0.36 & -0.83 & 0.19 & 0.02 & -- & -- & -- & -- & -- & 0.27 & -0.13 & -0.47 \\
\hline & -2 & -0.12 & $0.66^{*}$ & 0.08 & 0.04 & - & -- & -- & -- & - & -0.23 & $0.31 *$ & 0.30 \\
\hline & -3 & -0.47 & -0.00 & $-0.31 *$ & -0.22 & -- & -- & -- & -- & -- & 0.75 & $-0.50 *$ & -0.14 \\
\hline & -4 & $0.61 *$ & 0.01 & 0.13 & $0.33 *$ & -- & -- & -- & -- & -- & -0.63 & 0.15 & -0.05 \\
\hline \multirow{5}{*}{$\begin{array}{l}\text { Stock Market Excess } \\
\text { Returns }\end{array}$} & 0 & -1.99 & 1.84 & $\begin{array}{l}-1.370 \\
\end{array}$ & -2.480 & -- & -- & -- & -- & -- & 5.630 & -1.390 & -1.160 \\
\hline & -1 & -5.06 & 14.39 & $-2.83 *$ & -2.03 & -- & -- & -- & -- & -- & 5.42 & -0.59 & -5.22 \\
\hline & -2 & -8.10 & -4.54 & -1.61 & -1.33 & -- & -- & -- & -- & -- & -0.73 & $-9.47 *$ & -4.78 \\
\hline & -3 & -4.53 & 10.01 & -1.53 & $-7.63 *$ & -- & -- & -- & -- & -- & -21.22 & $-3.79 *$ & $-10.42^{*}$ \\
\hline & -4 & 2.53 & 2.14 & -1.21 & -2.33 & -- & -- & -- & -- & -- & -7.78 & $-2.74 *$ & -1.28 \\
\hline \multirow{5}{*}{$\begin{array}{l}\text { Stock Market Excess } \\
\text { Returns Interacted } \\
\text { with the IDC } \\
\text { Indicator Variable }\end{array}$} & 0 & 1.14 & 1.69 & 0.32 & 1.93 & -- & -- & -- & -- & -- & $\begin{array}{l}-6.35 \\
\end{array}$ & $-8.72 *$ & -3.79 \\
\hline & -1 & 0.68 & -2.62 & 1.17 & -2.30 & -- & -- & -- & -- & -- & -7.64 & -2.93 & 2.59 \\
\hline & -2 & 1.22 & 5.47 & 0.95 & -2.10 & - & -- & -- & -- & -- & -12.97 & 2.47 & 2.32 \\
\hline & -3 & 1.25 & -2.99 & 1.50 & 5.59 & -- & -- & -- & -- & -- & 16.66 & 2.28 & 8.84 \\
\hline & -4 & -2.48 & 7.66 & -1.18 & 1.47 & -- & -- & -- & -- & -- & -5.39 & 1.11 & -1.74 \\
\hline $\mathrm{R}^{2}$ & & 0.817 & 0.972 & 0.939 & 0.935 & -- & -- & -- & -- & -- & 0.975 & 0.756 & 0.761 \\
\hline
\end{tabular}


involve a substantial amount of "art" until better sources of bond market information become available.

Going forward, it seems likely that the quality and availability of bond prices will improve as fixed-income market players develop new systems for trading, underwriting and distributing bonds as well as dissemination of their market research to institutional investors. For example, by early 2000 , there were 39 on-line trading and underwriting systems in operation or in the development phase. ${ }^{58}$ Such new systems may not only improve bond market efficiency, but also provide direct access for retail investors, increase transparency and liquidity, and lower the cost of data collection for prices, trading volumes, and bid-ask spreads. Importantly, as such developments materialize, there may be fewer differences between alternative sources of bond market information. Such an evolution would facilitate the time-series analysis that would complement supervisory monitoring of debt spreads. Regulatory initiatives to enhance the transparency of LCBOs may also improve the information content of bond prices. ${ }^{59}$

\section{CONCLuSion}

Given the empirical findings that subordinated debt yields are risk-sensitive, it is not surprising that bank supervisors and market participants have been and continue to use such spreads to monitor depository institutions. The banking literature has provided some guidance in how to use spreads for these purposes, but many questions remain unanswered.

Here, bank holding company subordinated debt spreads from alternative data sources (Bloomberg, Interactive Data Corporation and two broker dealers) have been used to develop criteria for what bonds should be used for supervisory surveillance purposes. Using weekly time-series data (January 1997-October 1999, inclusive) on 265 bonds issued by 40 bank holding companies, the data on subordinated debt spreads were found to be most consistent across

\footnotetext{
${ }^{58}$ See Clow (2000, pp. 41-44).
}

${ }^{59}$ In 2000, the Federal Reserve Board, in consultation with the Office of the Comptroller of the Currency and the Securities Exchange Commission, created a private sector advisory group of bank and securities firm executives, under the chairmanship of Walter Shipley, to study and advise the Board on public disclosure issues. In March 2001, the agencies issued formal supervisory guidance encouraging the largest banking organizations and securities firms to use the recommendation of this private sector advisory group, which called for enhanced voluntary efforts to disclose credit management, credit risk, and trading positions in ways best designed to fit the policies of such institutions and to meet the risk analysis needs of other market participants, including quarterly disclosure of some market risk information, previously disclosed annually, and enhanced quarterly disclosures about credit concentrations and credit quality. 
sources for the bond issues that are most liquid. The analysis suggests that the liquidity of a bond depends on its issuance size, on the age of an issue, on whether the issuer is classified by bank supervisors as a large, complex, banking organization, and on the overall liquidity of the bond market. Indeed, spread data are most consistent across data sources for bonds issued by large, complex, organizations, that have been outstanding less than three years and that have an issuance size greater than $\$ 150$ million.

Even though there are substantial differences in levels of spreads for individual bonds across data sources, there is a high degree of concordance in rankings of banking organizations by their minimum spread across issues, and this concordance rises with greater liquidity in the overall bond market. Furthermore, there is considerable agreement about which banking holding companies, or large, complex, banking organizations, are in the extreme tails of the distribution of spreads at each point in time. The concordance in rankings across data sources supports the view that there is information content in subordinated debt spreads that could be useful for supervisory surveillance purposes.

Federal Reserve experience with monitoring both subordinated debt spreads and estimated default frequencies derived from equity price data and balance sheet information using the KMV model suggests that the time-series movements of such information have been, at times, difficult to interpret. Not surprisingly, the most interesting cases for bank supervisors are those where these two measures of a banking organization's condition appear to disagree with one another, or where market assessments disagree with independent supervisory assessments. Sometimes these differences can be attributed to a violation in the assumptions that underlie the KMV model. Sometimes these differences appear to arise because the bond market investors are wary of a change in business or investment strategy, while the stock market investors can participate in the up-side gains from such changes. Sometimes differences arise because the bonds that were considered were not actively-traded. And sometimes, the supervisory assessments disagree with what both markets would indicate about the condition of the banking organization.

Time-series methods could potentially be used to more rigorously address differences between signals from the equity and bond markets. One barrier to such methods, however, appears to be the lack of consistent bond market information. At the very least, there is currently 
considerable disagreement about the movements of debt prices over time across vendor data sources. Importantly, the effects of banking organization-specific risks and systematic factors on bank subordinated debt spreads are significantly different across vendor data sources.

Unfortunately, the interpretation of subordinated debt spreads has been made more complex by several bond market developments. First, liquidity in the bond market has not returned to the level observed before the Russian default. Second, reduced Treasury financing needs have lowered the supply of on-the-run Treasury securities at the longer-end of the maturity spectrum, precisely the maturities typically issued by depository institution holding companies in the subordinated debt market. And third, bank holding companies have dramatically reduced the number of issues over 1998 and 1999, and at the same time some holding companies have greatly increased the size of their issues. Such developments have affected the time-series movements of subordinated debt spreads and reinforce the view that their interpretation is both an "art" and a "science" not only for bank supervisors, but also for other third-parties that would apply indirect market discipline to depository institution holding companies and their affiliated depository institutions.

Even with these caveats in mind, however, we view the overwhelming weight of the results presented here as clearly supporting the use of subordinated debt spreads and other market data for supervisory surveillance. Just as clearly, much care must be used when interpreting such data, and continued research and development seems highly justified. 


\section{REFERENCES}

Avery, Robert B., Terrence M. Belton, and Michael A. Goldberg, 1988, "Market Discipline in Regulating Bank Risk: New Evidence from the Capital Markets," Journal of Money, Credit and Banking, November, pp. 547-610.

Berger, Allen N., Sally M. Davies, and Mark J. Flannery, 2000, “Comparing Market and Supervisory Assessments of Bank Performance: Who Knows What When?" Journal of Money, Credit, and Banking, 32 (3), August, pp. 641-67

Board of Governors of the Federal Reserve System, 1999, "Using Subordinated Debt as an Instrument of Market Discipline," Staff Study \#172, December.

Board of Governors of the Federal Reserve System and United States Department of the Treasury, 2000, The Feasibility and Desirability of Mandatory Subordinated Debt, A Report by the Board of Governors of the Federal Reserve System and the Secretary of the U.S. Department of Treasury, Submitted to Congress Pursuant to Section 108 of the Gramm-Leach-Bliley Act of 1999, December.

Clow, Robert, 2000, "After Sitting Out the First Wave of the Internet Revolution, the Fixed Income Market is Eyeball to Eyeball with the Future," Institutional Investor, February, pp. 41-44.

Covitz, Daniel M., Diana Hancock and Myron L. Kwast, 2000, "Mandatory Subordinated Debt: Would Banks Face More Market Discipline?" mimeo, Board of Governors of the Federal Reserve System, Washington, DC, December.

DeFerrari, Lisa M. and David E. Palmer, 2001, "Supervision of Large Complex Banking Organizations, Federal Reserve Bulletin, 87, February, pp. 47-57.

DeYoung, Robert, Mark J. Flannery, William W. Lang and Sorin M. Sorescu, 2001, "The nformational Advantage of Specialized Monitors: The Case of Bank Examiners," Journal of Money, Credit and Banking, 33, forthcoming.

Elton, Edwin J., Martin J. Gruber, Deepak Agrawal and Christopher Mann, 2000, "Explaining the Rate Spread on Corporate Bonds, The Journal of Finance, 56 (1), February, pp. 247277.

Evanoff, Douglas D. and Larry D. Wall, 2000a, "Subordinated Debt as Bank Capital: A Proposal for Regulatory Reform," Economic Perspectives, Federal Reserve Bank of Chicago, Second Quarter, pp. 40-53.

Evanoff, Douglas D. and Larry D. Wall, 2000b, "Subordinated Debt and Bank Capital Reform," Working Paper 2000-07, Federal Reserve Bank of Chicago, August. 
Fama, Eugene F. and Kenneth R. French, 1993, "Common Risk Factors in the Returns on Stocks and Bonds," Journal of Financial Economics, 33, pp.3-56.

Fisher, Mark, Douglas Nychka and David Zervos, 1995, "Fitting the Term Structure of Interest Rates with Smoothing Splines," Finance and Economics Discussion Series, \#95-1, Board of Governors of the Federal Reserve System, January.

Flannery, Mark J., 1998, "Using Market Information in Prudential Bank Supervision: A Review of the U.S. Empirical Evidence," Journal of Money, Credit, and Banking, 30, pp. 273305

Flannery, Mark J. and Sorin M. Sorescu, 1996, "Evidence of Bank Market Discipline in Subordinated Debenture Yields: 1983-1991,” Journal of Finance, 51 (4), September, pp. 1347-1377.

Gorton, Gary and Anthony M. Santomero, 1990, "Market Discipline and Bank Subordinated Debt," Journal of Money, Credit and Banking, February, pp. 119-128.

Hassan, M. Kabir, Gordon V. Karels and Manfred O. Peterson, 1993, “Off-Balance Sheet Activities and Bank Default-Risk Premia: A Comparison of Risk Measures," Journal of Economics and Finance, 17 (3), Fall, pp. 69-83.

Jagtiani, Julapa, George Kaufman, and Catharine Lemieux, 2000, "Do Markets Discipline Banks and Bank Holding Companies? Evidence from Debt Pricing," Federal Reserve Bank of Chicago, Emerging Issues Series, S\&R-99-3R, June.

Jagtiani, Julapa and Catharine Lemieux, 2000, "Stumbling Blocks to Increasing Market Discipline: A Note on Bond Pricing and Funding Strategy Prior to Failure, Federal Reserve Bank of Chicago Emerging Issues Series, S\&R-98-8R, April.

Jones, David S. and Kathleen Kuester King, 1995, “The Implementation of Prompt Corrective Action: An Assessment," Journal of Banking and Finance, 19, June, pp. 491-510.

Lang, William W. and Douglas D. Robertson, 2000, “A Retrospective Analysis of Subordinated Debt as a Trigger for Regulatory Intervention," manuscript, Office of the Comptroller of the Currency, December 21.

Meyer, Laurence H., 1999, "Market Discipline as a Complement to Bank Supervision and Regulation," remarks before the Conference on Reforming Bank Capital Standards, Sponsored by Ernst \& Young and AEI-Brookings Joint Center on Regulatory Studies, New York, New York, June 14

Mood, Alexander M., Franklin A. Graybill, and Duane C. Boes, 1974, Introduction to the Theory of Statistics, third edition, Mc Graw-Hill Series in Probability and Statistics, Mc GrawHill Book Company: New York. 
Nunn, Kenneth P., Jr., Joanne Hill, and Thomas Schneeweis, 1986, "Corporate Bond Price Data Sources and Return/Risk Measurement," Journal of Financial and Quantitative Analysis, 21 (2), June, pp. 197-208.

Salig, Oded and Arthur Warga, 1989, "Bond Price Data and Bond Market Liquidity," Journal of Financial and Quantitative Analysis, 24 (3), September, pp. 367-378.

U.S. Shadow Financial Regulatory Committee, 2000, Reforming Bank Capital Regulation: A Proposal by the U.S. Shadow Financial Regulatory Committee, AEI Studies on Financial Market Deregulation, AEI Press: Washington DC, March.

Warga, Arthur D., 1991, "Corporate Bond Price Discrepancies in the Dealer and Exchange Markets," The Journal of Fixed Income, 1 (3), December, pp. 7-16.

Warga, Arthur D. and Ivo Welch, 1993, “Bondholder Losses in Leveraged Buyouts," Review of Financial Studies, 6 (4), Winter, pp. 959-982 